\title{
CLASSIFYING VENTURE CAPITAL BACKED OPEN SOURCE SOFTWARE STARTUPS USING PUBLICLY
}

\section{AVAILABLE INFORMATION}

\author{
by \\ Hua Ye \\ A thesis submitted to the Faculty of Graduate Studies and Research \\ in partial fulfillment of the requirements for the degree of \\ Master of Applied Science in Technology Innovation Management
}

\author{
Department of Systems and Computer Engineering \\ Carleton University \\ Ottawa, Canada, K1S 5B6
}

July, 2008

(C) Copyright Hua Ye 2008 


$\begin{array}{ll}\begin{array}{l}\text { Library and } \\ \text { Archives Canada }\end{array} & \begin{array}{l}\text { Bibliothèque et } \\ \text { Archives Canada }\end{array} \\ \begin{array}{l}\text { Published Heritage } \\ \text { Branch }\end{array} & \begin{array}{l}\text { Direction du } \\ \text { Patrimoine de l'édition }\end{array} \\ \begin{array}{l}\text { 395 Wellington Street } \\ \text { Ottawa ON K1A 0N4 } \\ \text { Canada }\end{array} & \begin{array}{l}\text { 395, rue Wellington } \\ \text { Ottawa ON K1A 0N4 } \\ \text { Canada }\end{array}\end{array}$

Your file Votre référence ISBN: 978-0-494-44062-9

Our file Notre référence

ISBN: 978-0-494-44062-9

NOTICE:

The author has granted a nonexclusive license allowing Library and Archives Canada to reproduce, publish, archive, preserve, conserve, communicate to the public by telecommunication or on the Internet, loan, distribute and sell theses worldwide, for commercial or noncommercial purposes, in microform, paper, electronic and/or any other formats.

The author retains copyright ownership and moral rights in this thesis. Neither the thesis nor substantial extracts from it may be printed or otherwise reproduced without the author's permission.
AVIS:

L'auteur a accordé une licence non exclusive permettant à la Bibliothèque et Archives Canada de reproduire, publier, archiver, sauvegarder, conserver, transmettre au public par télécommunication ou par l'Internet, prêter, distribuer et vendre des thèses partout dans le monde, à des fins commerciales ou autres, sur support microforme, papier, électronique et/ou autres formats.

L'auteur conserve la propriété du droit d'auteur et des droits moraux qui protège cette thèse. $\mathrm{Ni}$ la thèse ni des extraits substantiels de celle-ci ne doivent être imprimés ou autrement reproduits sans son autorisation.
In compliance with the Canadian Privacy Act some supporting forms may have been removed from this thesis.

While these forms may be included in the document page count, their removal does not represent any loss of content from the thesis.
Conformément à la loi canadienne sur la protection de la vie privée, quelques formulaires secondaires ont été enlevés de cette thèse.

Bien que ces formulaires aient inclus dans la pagination, il n'y aura aucun contenu manquant.

\section{Canada}




\section{ABSTRACT}

This research uses a data mining process and information on companies' websites to classify 61 venture capital (VC) backed open source software (OSS) startups. It delivers a classification for OSS startups and observations about their market offers which are relevant to: (i) top management teams who wish to attract VC funding; (ii) Canadian VC investors who do not fund OSS startups; (iii) academics who are interested in data mining; and (iv) entrepreneurs who need to define their companies' market offers. The results suggest that open source companies seek to concurrently add value to their customers and the external communities on which they depend. They also suggest that the market offers of VC funded startups can be grouped into: (i) products and applications; (ii) consulting, training and testing services; and (iii) commercial licenses and support. The results from this research are consistent with previous research that classified market offers that rely on open source projects and ways in which companies integrate OSS into their market offers. 


\section{ACKNOWLEDGEMENTS}

I am deeply grateful to my thesis supervisor Professor Antonio J. Bailetti for his tremendous dedication, encouragement, guidance, and suggestions in the various stages of the development of this thesis. He guided me with great patience throughout this study.

I would like to thank Professor John Callahan for his constructive suggestions throughout the gate review process. I also would like to thank Professor Thomas Kunz for his advice on this research and Professor Michael Weiss for his suggestions on the data mining process.

I am also thankful to Professor Stoyan Tanev, Professor Steven Muegge, and Professor Douglas King, who provided suggestions during my gate presentations.

I thank my parents and my wife Lu Yang for their love, continuous support, encouragement and patience during the completion of my graduate program. I will forever be grateful to them.

The support received from Nortel and the Talent First Network for this research is gratefully acknowledged. 


\section{TABLE OF CONTENTS}

ABSTRACT

ACKNOWLEDGEMENTS ......................................................................................... iii

TABLE OF CONTENTS.......................................................................................... iv

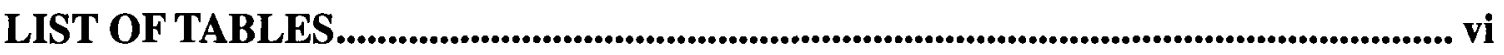

LIST OF FIGURES ............................................................................................................................. vii

LIST OF APPENDICES................................................................................................. viii

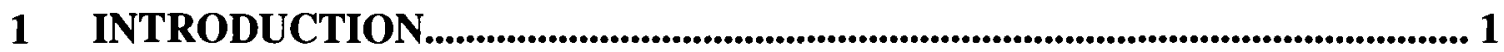

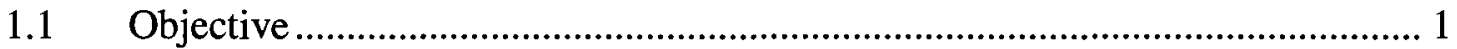

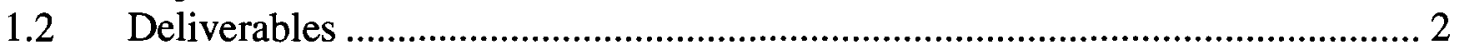

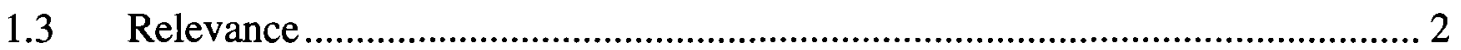

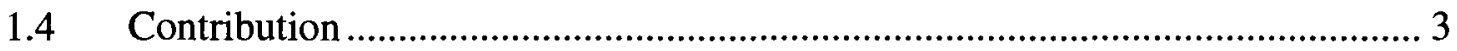

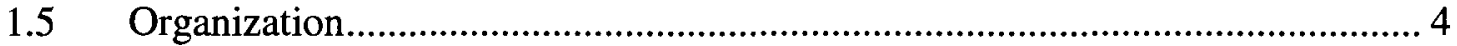

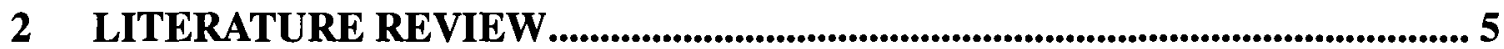

$2.1 \quad \mathrm{VC}$ investment in OSS companies..............................................................

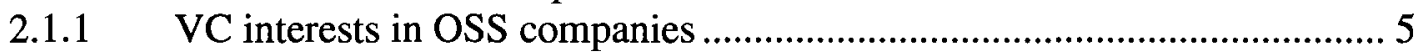

2.1.2 Ways to evaluate OSS startups …………….......................................... 8

$2.2 \quad$ Websites as corporate identities........................................................................ 11

2.2.1 Corporate identity ................................................................................ 11

2.2.2 Corporate identities demonstrated by websites........................................... 13

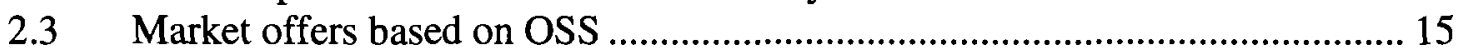

$2.4 \quad$ Open source community development................................................................ 18

2.4.1 Rationales for open source community.................................................. 18

2.4.2 Community-based innovation ............................................................. 19

2.4.3 Open source community ......................................................................... 22

2.4.4 Relationships between OSS companies and their communities ............... 26

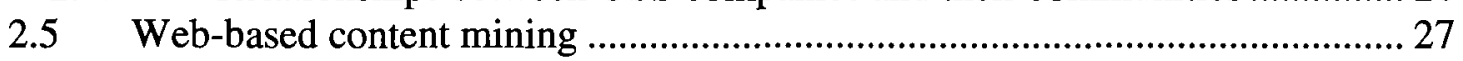

2.5.1 Content analysis of websites................................................................. 27

2.5.2 Content mining approaches................................................................... 30

2.6 Lessons learned from the literature review ................................................. 31

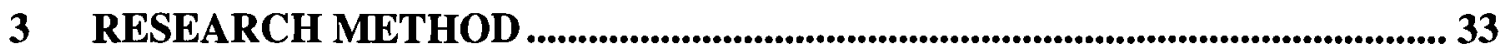

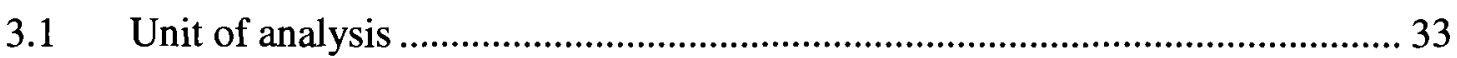

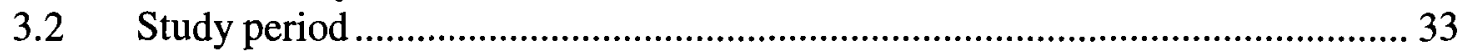

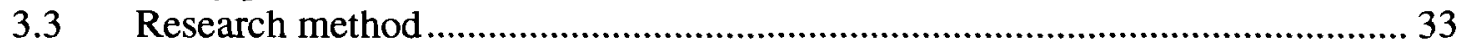

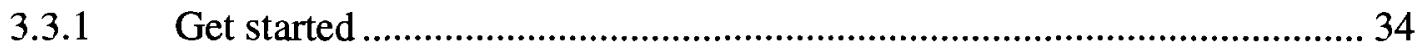

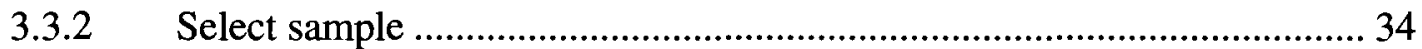

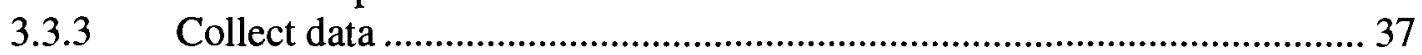

3.3.4 Analyze data.................................................................................... 39

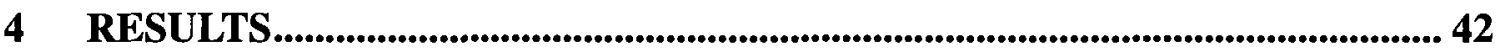




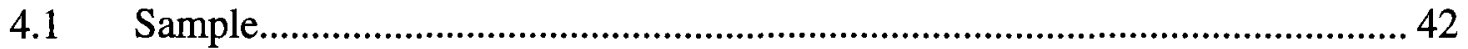

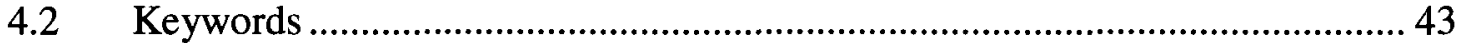

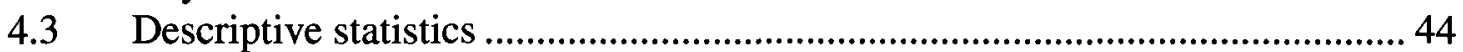

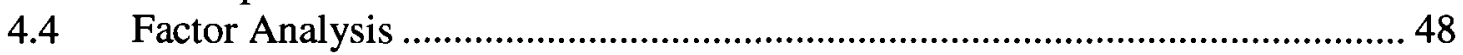

4.5 Summary of the results applied to the $61 \mathrm{VC}$ funded OSS startups .................53

5 DISCUSSION OF RESULTS..................................................................... 58

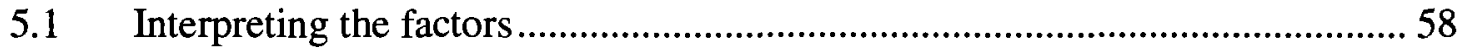

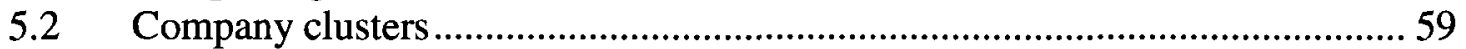

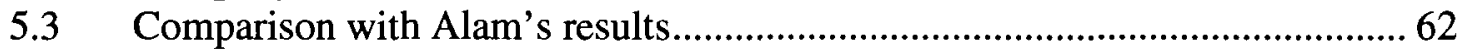

5.4 Importance of wiki, blog and forums to community development...................65

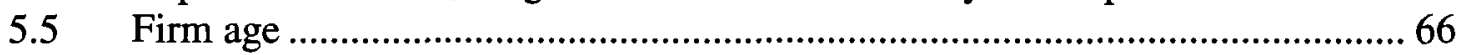

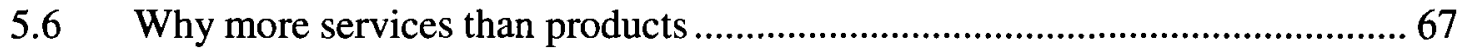

6 CONCLUSIONS, LIMITATIONS, AND FUTURE RESEARCH .................... 68

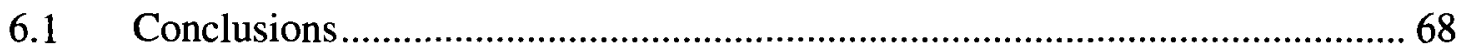

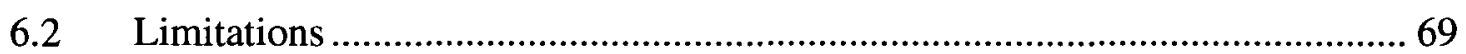

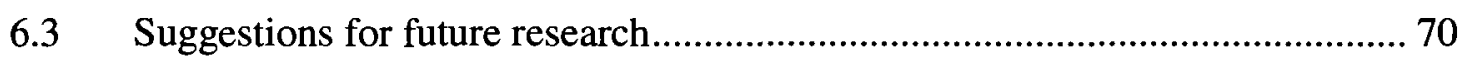

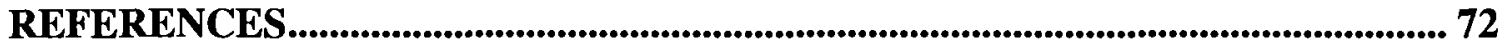

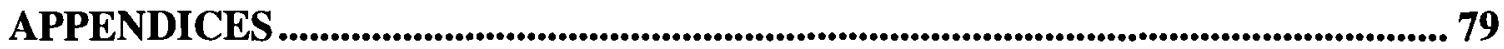




\section{LIST OF TABLES}

Table 1: Literature on the VC interests in OSS companies ................................................ 7

Table 2: Literature on the ways to evaluate OSS startups ................................................. 11

Table 3: Literature on corporate identity ........................................................................ 13

Table 4: Literature on corporate identities demonstrated by websites ............................... 15

Table 5: Literature on market offers reviewed by Alam (2006) ....................................... 16

Table 6: Ten ways to integrate OSS identified by Alam (2006)........................................ 17

Table 7: Literature on OSS market offers................................................................. 18

Table 8: Literature on the rationales for open source communities (Dahlander and

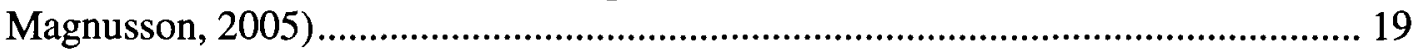

Table 9: Literature on the community-based innovation in OSS ....................................... 21

Table 10: Literature on open source communities............................................................. 25

Table 11: Relationships between OSS companies and their communities (Dahlander and

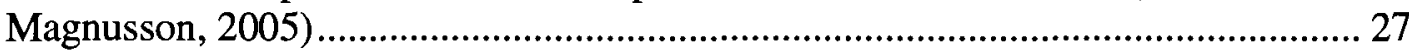

Table 12: Literature on content analysis of websites........................................................ 29

Table 13: Literature on content mining approaches .......................................................... 31

Table 14: Steps in research method ......................................................................... 34

Table 15: Descriptive statistics for the variables representing keywords (sample size $=61$ )

Table 16: Descriptive statistics for the total number of pages on the firm's website (sample size = 61) ............................................................................................. 46

Table 17: Descriptive statistics for the transformed variables representing keywords

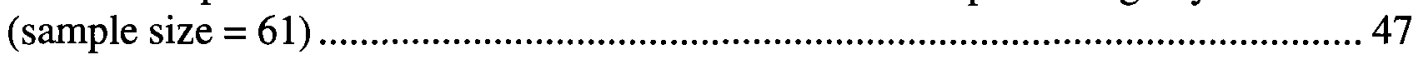

Table 18: Commonalities for the variables used in the Factor Analysis with Alpha Factoring as the extraction method (sample size $=61$ ) .............................................5 50

Table 19: Kaiser-Meyer-Olkin and Bartlett's test (sample size $=61$ ).............................. 50

Table 20: Total variance explained (sample size $=61$ ) ............................................... 51

Table 21: Results of Factor Analysis (sample size = 61) .............................................. 52

Table 22: Identification and classification of the $61 \mathrm{VC}$ funded startups........................... 54

Table 23: Number of companies by code ................................................................... 56

Table 24: Interpretation of the five factors .................................................................. 59

Table 25: Comparing the results of the Factor Analysis with the market offers identified

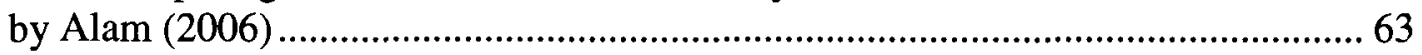

Table 26: Comparing the results of the Factor Analysis with the ways to integrate OSS identified by Alam (2006) 64 


\section{LIST OF FIGURES}

Figure 1: Knowledge exchange in a virtual organization (Rothfuss, 2002) .................... 23

Figure 2: Basic OSS community..................................................................................... 24

Figure 3: Process used to identify VC backed OSS startups ................................................ 37

Figure 4: VC funded OSS startups in the sample categorized by year founded................ 43

Figure 5: Scree plot for the VC funded OSS startups (sample size $=61$ ) ........................ 51

Figure 6: VC funded OSS startups grouped using the codes in Table 23 (sample size $=61$ ) 


\section{LIST OF APPENDICES}

Appendix A: List of the $61 \mathrm{VC}$ funded OSS startups included in the sample.

Appendix B: List of companies' market offers and community development activities . 82 


\section{INTRODUCTION}

The first quarter of 2008 was the most successful quarter in history in terms of open source software (OSS) startups raising venture capital (VC) funding. Yet, not a single OSS startup in Canada received VC funding and not a single VC fund in Canada invested in OSS companies.

\subsection{Objective}

The objective of this research is to classify VC funded OSS startups in terms of the information on their market offers and businesses that is available online.

For the purpose of this research, an OSS startup refers to a company that: (i) was established after 2000; (ii) has no public offering; (iii) is not a subsidiary of a parent company; and (iv) generates revenue through market offers that rely on OSS.

A VC funded OSS startup refers to an OSS startup that has received institutional financing from one or more independent VC firms and bank-based VC firms. OSS startups that only use funds from founders, friends, family, and angel investors are not deemed to be VC funded.

A market offer refers to the generic product or service and the set of augmenting services, programs, and systems that a firm offers potential customers (Alam, 2006; Anderson, Carpenter, and Narus, 2001). 


\subsection{Deliverables}

The deliverables of this research are:

1. A classification of VC funded OSS startups using information published on their websites.

2. Observations about the market offers of VC funded OSS startups that are relevant to top management teams of startups, investors, academics, and entrepreneurs.

\subsection{Relevance}

This research is relevant to: (i) top management teams of OSS startups who wish to attract VC funding; (ii) Canadian VC investors who do not fund OSS startups; (iii) academics who are interested in web-based content mining methodologies; and (iv) entrepreneurs who need to define their companies' market offers.

Top management teams of startups who wish to attract VC funding will find this research relevant because they may be interested in knowing the types of market offers which VC backed companies develop and sell.

This research is relevant to VC investors in Canada who do not yet fund OSS startups. They may be surprised to learn the extent to which venture capitalists in the United States invest in OSS startups.

This research provides academics with a "how to" approach to mine information on companies' websites. This knowledge will enable opportunities for further research. 
Academics who are interested in web-based content mining methodologies will find the process used in this research relevant.

Finally, this research will be relevant to the entrepreneurs who drive OSS startups. They will be able to use the results of the Factor Analysis as a template when deciding how to (i) structure their portfolios of products and services, and (ii) add value to the external communities on which they depend.

\subsection{Contribution}

This research makes at least three contributions. First, it provides evidence that VC funded OSS startups seek to concurrently add value to their customers as well as the external communities anchored around the OSS projects and customers on which their market offers rely.

Second, this research contributes a categorization of market offers from VC funded OSS startups. These market offers can be categorized into three groups: (i) products and applications; (ii) consulting, training and testing services; and (iii) commercial licenses and support.

Third, this research contributes new insights about the breakdown of the market offers from VC funded OSS startups. A greater number of VC funded OSS startups sell services than products and applications. Most startups that sell products or applications, also sell services. This suggests that VCs are funding OSS startups for reasons other than their $R \& D$ capability. 


\subsection{Organization}

This thesis is organized into six chapters. Chapter 1 provides the introduction. Chapter 2 provides the literature review. Chapter 3 describes the research method used when undertaking this research. Chapter 4 provides the results of this research. Chapter 5 provides a discussion of the results. Finally, Chapter 6 provides conclusions, limitations and suggestions for future research. 


\section{LITERATURE REVIEW}

This chapter has six sections. The first section examines the studies on VC investment in OSS companies. The second section reviews the literature on websites as corporate identities. The third section reviews the literature on market offers that rely on OSS. The fourth section reviews the literature on open source community development. The fifth section reviews the literature on web based content mining. Finally, the sixth section discusses the lessons learned from the literature review.

\subsection{VC investment in OSS companies}

In this section, the literature on VC interests in OSS companies and ways to evaluate OSS startups is reviewed.

\subsubsection{VC interests in OSS companies}

A recent 451 Group report (Aslett, 2008) noted that: (i) the first quarter of 2008 was the most successful quarter in history in terms of open source vendors raising VC funding, with the amount raised being $\$ 203.75$ million, up from $\$ 100.40$ million in the same quarter of 2007; and (ii) the amount of VC funding in the first quarter of 2008 was greater than the previous record of $\$ 193.7$ million in the fourth quarter of 2006 . According to figures collated by Computer Business Review (Aslett, 2007), venture capitalists invested $\$ 475.2$ million in open source vendors in 2006 , up $61.6 \%$ from $\$ 294.0$ million in 2005 . In contrast, the amount of money invested in software vendors actually decreased from $\$ 1.66$ billion in 2005 to $\$ 1.60$ billion in 2006 . 
This suggests that it is hard to raise capital with the old traditional model, and there could be more money to be made from open source than proprietary software models in the long term (Aslett, 2007). One major reason for this trend is that venture capitalists are looking for a market with high growth at the early adopter stage. OSS is enabling the creation of thousands of entrepreneurs who open up previously untapped portions of the market (Sterne and Herring, 2006). The fact that large corporations are shifting to open source is another reason why venture capitalists are investing in OSS companies (Cook, 2005). Therefore, as a disruptive technology, OSS will nibble, or maybe even someday gobble, the customer base of commercial software companies (Blau, 2006). OSS companies serve customers by either developing extensions to the existing OSS products or implementing business solutions that significantly rely on OSS (Sterne and Herring, 2006).

What attracts investors to OSS companies is the higher probability of innovative ideas, the quicker time to market, and the ability to develop niche markets (Byfield, 2008) and communities (Pienaar, 2007). However, the sustainability of open source business models is still not proven, and the question "where is the value?" needs to be solved (Pienaar, 2007). Haapanen (2007) suggested that OSS startups should know their products and services well, and assess the risks and opportunities. OSS startups need to plan in advance how to mitigate the risks in the business models and prepare from the beginning for possible VC transactions.

Table 1 presents a summary of the literature on the VC interests in OSS companies. 
Table 1: Literature on the VC interests in OSS companies

\begin{tabular}{|c|c|}
\hline Study & Highlights \\
\hline Pienaar (2007) & $\begin{array}{l}\text { VC interests in OSS companies: } \\
\text { (i) Sustainable business models and size of community (developers and } \\
\text { users); } \\
\text { (ii) Open source companies considered an ecosystem by venture capitalists. } \\
\text { - What is needed to be more successful: } \\
\text { (i) CIOs do not care about source code, and they care about support; } \\
\text { (ii) Need a clear proposition of value and differentiation; } \\
\text { (iii) Need a clear strategy on how to work with and leverage community: } \\
\text { a) Strong partner model is key to success, e.g., SugarCRM; } \\
\text { b) Accountability of eco-community. } \\
\text { (iv) Scalability and security is still a major issue to compete with traditional } \\
\text { proprietary software companies for enterprise customers; } \\
\text { (v) Support and service level still weak: } \\
\text { a) Service level and project management thinking needs to improve; } \\
\text { b) How to get out of cost mindset. } \\
\text { - Where is the opportunity: } \\
\text { (i) Corporate customers are looking for solutions, not software modules; } \\
\text { (ii) The open source ecosystem plays an important role: } \\
\text { a) Open source community ecosystem, i.e., Free Software } \\
\text { Foundation (FSF), Open Source Initiative (OSI), Linux } \\
\text { Foundation, Apache Foundation, Eclipse Foundation, and so on; } \\
\text { b) Open source commercial ecosystem, i.e., original equipment } \\
\text { manufacturers (OEMs), independent software vendor (ISVs), } \\
\text { service providers, Open source companies, technology } \\
\text { consumers, investment community, startups, and so on. }\end{array}$ \\
\hline Haapanen (2007) & $\begin{array}{l}\text { - VC interests in OSS firms: } \\
\text { (i) Excellent business idea; } \\
\text { (ii) Exceptionally high potential for growth; } \\
\text { (iii) Value at the market; } \\
\text { (iv) Financial returns; } \\
\text { (v) Successful exit within the planned timeframe; } \\
\text { (vi) Awareness of risks related to transaction. } \\
\text { - OSS analysis: } \\
\text { (i) Information on OSS as part of products; } \\
\text { (ii) List of OSS components - completeness and accuracy of the listed } \\
\text { components; } \\
\text { (iii) List of OSS licenses and right holders; } \\
\text { (iv) Software architecture - information how the OSS components are used } \\
\text { in the product development as well as products. } \\
\text { Obvious OSS risks that may impact on VC transactions: } \\
\text { (i) Breach of OSS license terms: } \\
\text { a) Notice requirements; } \\
\text { b) Distribution of source code. } \\
\text { (ii) Contamination of proprietary code; } \\
\text { (iii) Unbalanced liabilities with regard to OSS in supply agreements; } \\
\text { (iv) Infringement of third party Intellectual Property Rights (IPRs); } \\
\text { (v) Dilution of own patents. }\end{array}$ \\
\hline
\end{tabular}




\begin{tabular}{|l|l|}
\hline Byfield (2008) & VC interests in OSS firms: \\
(i) The higher probability of innovative ideas: \\
a) Open source has a disruptive feature in technology and \\
distribution; \\
b) A successful innovation means a greater return on investment. \\
(ii) Build products more cheaply and market them in less time: \\
a) OSS builds on existing code and can benefit from community \\
contributions; \\
b) OSS companies produce a quicker return on investment. \\
(iii) The ability to develop niche markets that were previously too small to \\
develop profitably (e.g., Krugle): \\
a) OSS companies do not have to compete with the giants in their \\
b) A Aeld;
\end{tabular}

\subsubsection{Ways to evaluate OSS startups}

Innovation in small technology firms is difficult to finance because of four fundamental problems: high uncertainty, information asymmetry, intangible soft assets, and sensitivity to volatile market conditions (Callahan and Muegge, 2003). A VC valuation reflects both the entrepreneur's determination of the acceptable amount of ownership that may be given in return for the $\mathrm{VC}$, and the venture investor's determination of the risks and rewards of the investment (Callow and Larsen, 2003). Therefore, it is in the entrepreneur's best interest to understand the short-term and long-term capital requirements of the company, and work with investors to develop a financing strategy based on building value from one financing stage to the next and understanding how value will be measured.

VC valuation methodologies may differ by the stage of investment and the availability of quantitative and qualitative data. However, the basic components of VC valuation are universal. These include: proof of concept, the quality of the management team, human capital, technical assets, market size, intellectual property (IP), milestones achieved thus far, comparable company valuations, rationalized revenue forecasts, multiples of revenue, 
and so on.

Venture capitalists expend a great deal of time and resources to evaluate transactions, and screen deals based on such factors as investment stage, investment size, industry sector, geography, the strength of the core management team, future market and technology trends (Callahan and Muegge, 2003; Callahan and Charbonneau, 2003).

However, Puhakka and Jungman (2005) found that some venture capitalists recognized that there were distinctly different elements when evaluating OSS startups. Although more than $\$ 2$ billion has been invested in open source companies, the sustainability of open source business models is still not proven (Pienaar, 2007). For example, SourceForge shows relatively low revenues, and most open source companies are still sponsored. Expected cash flows are likely to be greater in OSS companies than those in similar traditional software companies thanks to the savings in licensing fees and innovation approaches. However, at the same time, the discount rate, or the cost of capital, is higher due to the uncertainties in the profitability of the business model, revenue streams, market acceptance, community commitment, competitive reactions, and the quality of software.

Wood (2005) proposed that before a product is released under an open source license, the line between open source and proprietary features should be clearly depicted, and the product segmentation should be implementable. He also indicated that venture capitalists may tend to invest in complementary technologies in the hope that their portfolio 
comprised of open source companies can help each other succeed. Entrepreneurs can find potential investment partners simply by studying existing open source investment announcements, and do not need to approach VC companies blindly (Byfield, 2008).

At the stage of the pre-money valuation, the early involvement of developers and users in the community, which contributes bug fixes or feedback on desired features, provides an early indication of whether an investment will pay off (Aslett, 2007; LaMonica, 2005). To some extent, in the consumer Internet space, the size and characteristics of the open source community can be used to project market share (Roblimo, 2006). Therefore, OSS startups need to emphasize a community-building approach, and focus on monetizing ancillary services like technical support.

Table 2 presents a summary of the literature on the ways to evaluate OSS startups. 
Table 2: Literature on the ways to evaluate OSS startups

\begin{tabular}{|l|l|}
\hline Study & Highlights \\
\hline Puhakka and & $\begin{array}{l}\text { Two case studies: BlueRun Ventures, and Nexit Ventures. } \\
\text { Jungman (2005) }\end{array}$ \\
& $\begin{array}{l}\text { It is widely accepted that the three key investment decision criteria are: } \\
\text { (i) management team; } \\
\text { (ii) market projections; } \\
\text { (iii) product. }\end{array}$ \\
& $\begin{array}{l}\text { The valuation of OSS companies is challenging, because there is yet neither history } \\
\text { nor guidelines, due to the uncertainties for example in: } \\
\text { (i) the profitability of business model; } \\
\text { (ii) revenue streams; } \\
\text { (iii) market acceptance; } \\
\text { (iv) community commitment; } \\
\text { (v) competitive reactions; } \\
\text { (vi) the quality of software. }\end{array}$ \\
\hline - The valuations on OSS startups are not made with transparent scientific methods, \\
but are rather results of negotiations.
\end{tabular}

\subsection{Websites as corporate identities}

\subsubsection{Corporate identity}

A corporate identity is a summation of those tangible and intangible elements that make any corporate entity distinct (Balmer, 2001). In 1995, the British Standards Institution 
defined corporate identity as what an organization is, what it stands for, what it does and how it goes about its business (Hicks, Libaers, Porter, and Schoeneck, 2006).

Corporate identity is multidisciplinary in scope and is a melding of strategy, structure, communication and culture. It is manifested through communication channels that encapsulate product and organizational performance, employee communication and behavior, controlled communication, stakeholder, and network discourse (Balmer, 2001).

Schmidt's (1995) identity mix comprises a quintet of elements, while Birkigt and Stadler's (1986) identity mix consists of a quartet of elements. Balmer and Soenen (1999) developed the ACID Test approach to differentiate four types of identity. Balmer (2001) acknowledged that there were two critical stages in communication (sending and receiving), and introduced a new category type, thus making a total of five identity types. The revised approach has been called Balmer's AC2ID Test.

Table 3 presents a summary of the literature on corporate identity. 
Table 3: Literature on corporate identity

\begin{tabular}{|l|l|}
\hline Study & Highlights \\
\hline Birkigt and & - Business identities includes: \\
Stadler (1986) & (i) Corporate personality; \\
& (ii) Corporate behavior; \\
(iii) Communication; & (iv) Symbolism. \\
\hline Schmidt (1995) & Business identities includes: \\
& (i) Corporate culture; \\
& (ii) Corporate behavior; \\
& (iii) Market condition and strategies; \\
& (iv) Product and services; \\
(v) Communication and design.
\end{tabular}

In general, all corporate identity theories focus on: (i) corporate design; (ii) corporate communication; and (iii) corporate behavior.

\subsubsection{Corporate identities demonstrated by websites}

Corporations use their websites as a vehicle for image building (Chun and Davies, 2001; Maynard and Tian, 2004) and dissemination of corporate information (Fisher, Oyelere, and Laswad, 2004). 
Opoku (2005) proposed that a web presence can be used to communicate core messages such as brand personalities. Berthon, Pitt, and Watson (1996) provided a vivid description of various websites' applications. Sullivan (1999) found that image creation is the most important function of corporate websites. Corporate websites have become powerful tools for promoting corporate identities and building relationships with audiences (Topalian, 2003).

Pollach (2005) used content analysis, quantitative linguistic analysis and discourse analysis to examine the "About Us" sections of 20 well-known corporate websites. He found that companies' self-presentation on the websites presents opportunities that are presented in Table 4. Opoku (2005) sought to exploit the potential of websites to assess corporate identity. He developed a dictionary of terms associated with each of the five dimensions of brand personality: sincerity, excitement, competence, sophistication, and ruggedness. The frequencies of the keywords on the websites of 30 business schools in the United States were then obtained, and the pattern of occurrence of the keywords was assessed to classify the business schools by their brand "personality".

Hicks et al. (2006) argued that corporate websites universally articulate corporate identities. Their study was similar in style to that of Opoku (2005). They began with a theoretically informed immersion in the text of the websites of 80 highly innovative small firms, and developed a set of keywords from their websites. The pattern of occurrence of the keywords was used to classify the commercialization strategies of these firms. 
Table 4 presents a summary of the literature on corporate identities as demonstrated by websites.

Table 4: Literature on corporate identities demonstrated by websites

\begin{tabular}{|c|c|}
\hline Study & Highlights \\
\hline Opoku (2005) & $\begin{array}{l}\text { A Web presence appears to be effective for: } \\
\text { (i) creating brand, product and corporate awareness and image; } \\
\text { (ii) providing product and other information; } \\
\text { (iii) handling customer complaints, queries and suggestions; } \\
\text { (iv) generating qualified leads; } \\
\text { (v) providing customers access to the extranet. }\end{array}$ \\
\hline $\begin{array}{l}\text { Berthon et al. } \\
\text { (1996) }\end{array}$ & $\begin{array}{l}\text { - Websites' applications include: } \\
\text { (i) providing detailed product information and specifications; } \\
\text { (ii) gaining access to previously unknown or inaccessible buying influences; } \\
\text { (iii) projecting a favorable corporate image; } \\
\text { (iv) fostering and encouraging consumer involvement with the product range; } \\
\text { (v) establishing interactivity, offering product samples, and building a } \\
\text { customer database; } \\
\text { (vi) handling customer complaints, questions, and suggestions, and providing } \\
\text { product distribution. }\end{array}$ \\
\hline Topalian (2003) & $\begin{array}{l}\text { - Communication is now significantly easier through advances in information } \\
\text { technology and the evolution of the Internet. } \\
\text { - Corporate websites could be very powerful vehicles for corporate identities. }\end{array}$ \\
\hline Pollach (2005) & $\begin{array}{l}\text { - Companies' self-presentation on the websites presents opportunities: } \\
\text { (i) Websites are capable of transmitting an unlimited amount of information } \\
\text { to all potential audiences, including customers, vendors, employees, job } \\
\text { seekers, investors, financial analysts, journalists, students, researchers and } \\
\text { the public at large; } \\
\text { (ii) Audiences have much more control over what they want to see than in } \\
\text { traditional media; } \\
\text { (iii) The messages companies send to their audiences are controlled } \\
\text { exclusively by the companies themselves; } \\
\text { (iv) Websites enable companies to learn more about their audiences by } \\
\text { including interactive features. }\end{array}$ \\
\hline $\begin{array}{l}\text { Opoku (2005), } \\
\text { Hicks et al. } \\
(2006)\end{array}$ & $\begin{array}{l}\text { - Corporate websites universally articulate corporate identities. } \\
\text { - A set of keywords on the websites were developed to assess identity. }\end{array}$ \\
\hline
\end{tabular}

\subsection{Market offers based on OSS}

Alam (2006) reviewed the critical literature on market offers and examined market offers that rely on OSS projects. Table 5 includes Alam's review of the market offer literature. 
Table 5: Literature on market offers reviewed by Alam (2006)

\begin{tabular}{|c|c|}
\hline Study & Highlights \\
\hline $\begin{array}{l}\text { Kotler and Turner } \\
\text { (1995) }\end{array}$ & $\begin{array}{l}\text { - A product or market offer is anything that is offered to the market for attention, } \\
\text { acquisition, use, or consumption that might satisfy a want or need. } \\
\text { - These add-ons might be in the form of packaging, customer services, } \\
\text { advertising, financing, and other things that deliver value to the customer. } \\
\text { - The five product levels include: } \\
\text { (i) core benefit: fundamental service or benefit the customer buys; } \\
\text { (ii) generic product: basic version of product; } \\
\text { (iii) expected product: attributes and conditions the buyer normally expects; } \\
\text { (iv) augmented product: distinguishes from others; } \\
\text { (v) potential product: augmentations and transformations that might } \\
\text { undergo in the future. }\end{array}$ \\
\hline Levitt (1980) & $\begin{array}{l}\text { The value of the market offer is proportion to the perceived ability to solve a } \\
\text { problem or meet a need. }\end{array}$ \\
\hline
\end{tabular}

Based on the model advanced by Kotler and Turner (1995) and Anderson, Carpenter, and Narus (2001), Alam (2006) identified 24 OSS market offers provided by 12 companies. He classified these market offers into six types: (i) hosting and content services; (ii) training and testing services; (iii) support services; (iv) subscription services; (v) commercial licenses; and (vi) products/applications. In addition, Alam (2006) identified ten ways companies integrated OSS into their market offers. He examined the extent of the integration between the OSS and the company's proprietary assets (minimal or comprehensive) and the extent to which OSS contributes to the value of the market offer (significant or insignificant).

Table 6 presents the ten ways companies integrated OSS into their market offers indentified by Alam (2006). 
Table 6: Ten ways to integrate OSS identified by Alam (2006)

\begin{tabular}{|c|c|c|c|c|}
\hline & \multicolumn{3}{|c|}{ Can OSS contribute significantly to the company's market offer? } \\
\hline & & \multicolumn{2}{|l|}{ No } & Yes \\
\hline 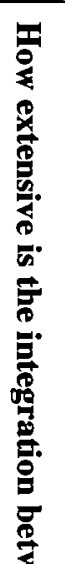 & 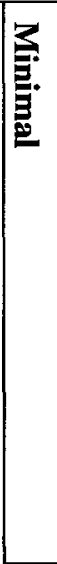 & & $\begin{array}{l}\text { OSS is used as one of the } \\
\text { components to the network that } \\
\text { delivers the hosting and content } \\
\text { services. }\end{array}$ & $\begin{array}{l}\text { (ii) OSS is used to anchor training and testing } \\
\text { services. } \\
\text { (iii) The company uses OSS projects it } \\
\text { established to create attractive market } \\
\text { offers. } \\
\text { (iv) The company integrates software from OSS } \\
\text { projects established by others and } \\
\text { proprietary software from other companies } \\
\text { into a stack, adds advanced functionalities, } \\
\text { perform tests, and certify the integrated } \\
\text { software. } \\
\text { (v) The company incorporates OSS from } \\
\text { partner companies, and uses commercial } \\
\text { and trademark licenses as its market offer. }\end{array}$ \\
\hline 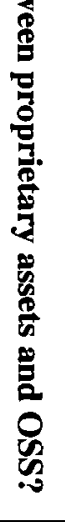 & 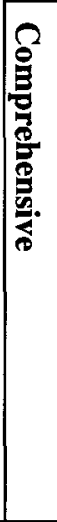 & & $\begin{array}{l}\text { OSS is integrated with proprietary } \\
\text { software or hardware into an } \\
\text { interface module that is a small part } \\
\text { of the product. }\end{array}$ & $\begin{array}{l}\text { (vii) OSS is integrated with proprietary software } \\
\text { and/or hardware to create a product or } \\
\text { application. } \\
\text { (viii) The company integrates OSS with network } \\
\text { infrastructure to provide subscription } \\
\text { services. } \\
\text { (ix) The company uses OSS to seed demand for } \\
\text { the company's proprietary application. } \\
\text { (x) The company integrates OSS with other } \\
\text { complementary products to work together } \\
\text { as a system; OSS community develops } \\
\text { complementary content that is required by } \\
\text { the software. }\end{array}$ \\
\hline
\end{tabular}

In seven open source strategies examined by Koenig (2004), five types of OSS market offers can be identified. After surveying the industry segment of open source in the United States, Pienaar (2007) found ten open source business models, in which six types of OSS market offers can be identified.

Table 7 presents a summary of the literature on OSS market offers. 
Table 7: Literature on OSS market offers

\begin{tabular}{|c|c|}
\hline Study & Highlights \\
\hline Alam (2006) & $\begin{array}{l}\text { - Six types of OSS market offers: } \\
\text { (i) Hosting and content services that rely on a content delivery network } \\
\text { allows content creators to outsource delivery of their digital multimedia } \\
\text { content, e.g., RealNetworks; } \\
\text { (ii) Training and testing services that provide professional certifications for } \\
\text { those who want to show they have the skills, knowledge, and capability } \\
\text { to work with the software, e.g., JBoss, MySQL, JBoss, Red Hat; } \\
\text { (iii) Support services that provide fixes to the software, advice and } \\
\text { suggestions for deploying the software in their customers' environment, } \\
\text { e.g., ActiveGrid, SpikeSource; } \\
\text { (iv) Subscription services that enable customers to subscribe to receive } \\
\text { updates, upgrades, monitoring and management capabilities of their } \\
\text { software deployments, e.g., JBoss, Sourcefire; } \\
\text { (v) Commercial licenses that provide undisputed rights to the software } \\
\text { products, e.g., SGI; } \\
\text { (vi) Products/applications that may provide advanced features and } \\
\text { capabilities over what is available in the open source version, e.g., } \\
\text { JasperSoft, Digium. }\end{array}$ \\
\hline Koenig (2004) & $\begin{array}{l}\text { - Five types of OSS market offers: } \\
\text { (i) Commercial licenses that require a metric by which customers are } \\
\text { charged, e.g., MySQL, Bitrock; } \\
\text { (ii) Consulting services that deliver a customer solution involving } \\
\text { integration of hardware, software and maintenance, e.g., Cognizant, } \\
10 \mathrm{X} \text {, Optaros; } \\
\text { (iii) Support services that provide engineering services, customer training } \\
\text { and education, e.g., Red Hat, Openlogic; } \\
\text { (iv) Hosted services that take software as a service (SaaS), e.g., Salesforce, } \\
\text { (v) Hardwaite; }\end{array}$ \\
\hline Pienaar (2007) & $\begin{array}{l}\text { Six types of OSS market offers: } \\
\text { (i) Commercial licenses; } \\
\text { (ii) Subscription services; } \\
\text { (iii) Freemium offers that provide basic services for free while charging a } \\
\text { premium for advanced or special features; } \\
\text { (iv) Professional services that include technical support, consulting, and } \\
\text { training and testing services; } \\
\text { (v) Hosting services that provide Web space for use by customers; } \\
\text { (vi) Applications and tools sales. }\end{array}$ \\
\hline
\end{tabular}

\subsection{Open source community development}

\subsubsection{Rationales for open source community}

Dahlander and Magnusson (2005) examined several studies on the incentives for taking part in open source communities. Table 8 shows a summary of the rationales for open source communities. 
Table 8: Literature on the rationales for open source communities (Dahlander and

Magnusson, 2005)

\begin{tabular}{|c|c|}
\hline Perspective & Motivation \\
\hline Economic & $\begin{array}{l}\text { - Monetary rewards (Hertel, Niedner, and Herrmann, 2003; Lerner and Tirole, } \\
\text { 2005) } \\
\text { - Low opportunity cost (Lakhani and von Hippel, 2003) } \\
\text { - Signaling incentives - the contributors are concerned about future careers (Lerner } \\
\text { and Tirole, 2002) }\end{array}$ \\
\hline Social & $\begin{array}{l}\text { - Belonging to a community (Raymond, 2001) } \\
\text { Intellectual challenges - helping others may increase self-esteem, demonstrating } \\
\text { technical expertise, earning respect and status, and responding to norms of } \\
\text { mutual aid (Himanen, 2001; Raymond, 2001) } \\
\text { - Altruism or general reciprocity (Raymond, 1999a) }\end{array}$ \\
\hline Technological & $\begin{array}{l}\text { Learning (Lakhani and von Hippel, 2003) } \\
\text { - Feedback and help (Raymond, 2001) } \\
\text { - Working with new technologies }\end{array}$ \\
\hline
\end{tabular}

Community members developing OSS are much more likely to be driven by social factors than traditionally employed software developers (Dahlander and Magnusson, 2005).

\subsubsection{Community-based innovation}

Partner or cooperative innovation combines elements of process and product innovation within a "network structure" to create a product-service response that neither partner can create by using its own resources (Walters and Rainbird, 2007). In contrast, communitydriven initiatives result in products more akin to a public good, leading to value capture that is diffused across an ecosystem (Chesbrough and Appleyard, 2007).

Consistent with the finding that larger companies were more likely to build on external knowledge (Almeida, Dokko, and Rosenkopf, 2003), West and Gallagher (2006) found 
that large IT firms with a broad scope of products were involved in open source because they could not ignore any significant source of external innovation that was available to rivals. Small companies aligned their innovation strategies with open source in order to seek niches unoccupied by competitors.

OSS development is an example of a horizontal innovation network supported by a community (von Hippel and von Krogh, 2003). Open source style R\&D is not only community based, but also adoptable for businesses (Ueda, 2006). Through the development community, additional functionality for OSS products can be developed to satisfy real customer needs far more rapidly than those for traditional proprietary software products (Wallace, 2006).

West and Gallagher (2006) identified three fundamental challenges for companies in applying the concept of open innovation: (i) finding creative ways to exploit internal innovation; (ii) incorporating external innovation into internal development; and (iii) motivating outsiders to supply an ongoing stream of external innovations. They found that the collaborative development using donated labor is a key component for open source innovation strategy. They further examined how the activities of companies in OSS supported their innovation strategies, and identified two approaches driven by the structural relationship of contributor-participants.

Table 9 presents a summary of the literature on the community-based innovation in OSS. 
Table 9: Literature on the community-based innovation in OSS

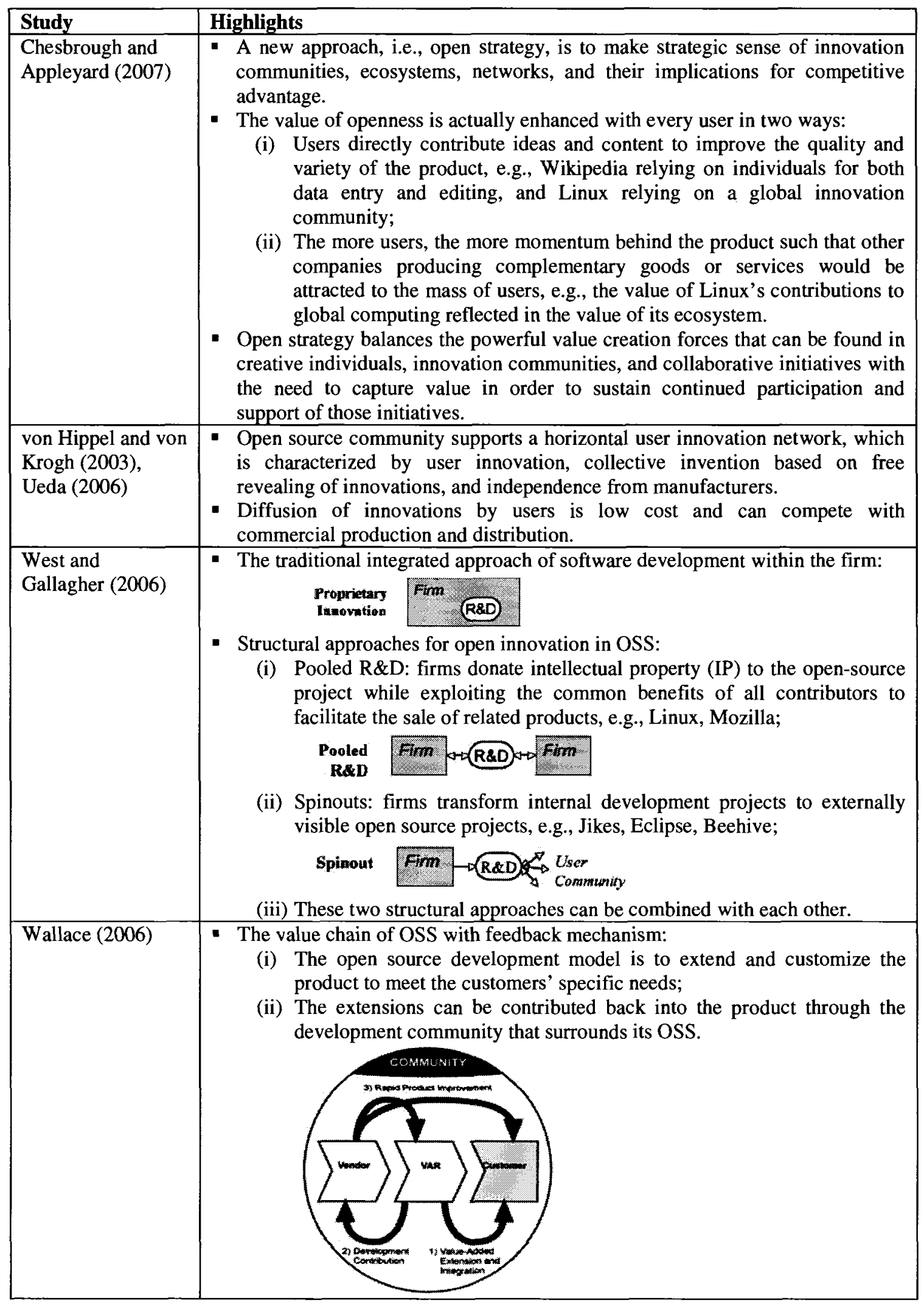




\subsubsection{Open source community}

The World Wide Web is the major platform for tools that people can use to communicate in their networks, and makes massive decentralized projects possible. A wide range of applications can be found, from static web pages to e-mail and blogs, and numerous social-software-mediated platforms that are essential for large scale conversations, (Weber, 2006). These tools make it easier to reference, store, retrieve, and archive online information or data. This makes collaboration in non-geographic communities more convenient (Benkler, 2006).

Communication channels are becoming more open and easily accessible for everybody. The transfer of information has become less costly and the quality of the information spread became almost independent of locations. Users join together in open source communities, which underlie a certain organization providing structure and tools useful for interaction to support the distribution of new innovations (von Hippel, 2005).

Research on large, successful open source projects, such as Linux and Apache, assumes that the size of the user-programmer community may be a key independent variable (West, 2003). Anecdotal evidence suggests that the major reason open source projects fail is due to a lack of users and contributors to do the work (West, 2003).

Figure 1 illustrates the Dafermos (2001) model. Rothfuss (2002) used this model to highlight the attributes of the virtual organization that are beneficial to the success of 
open source projects. He thought that the answer to the question, "what can the virtual organization do that the physical organization can not?", lay on the fact that the virtual organization generates massive knowledge and exploits it in the most effective way by bringing the physical organization, the surrounding industry, and the end users together.

Value chain analysis can be applied to the virtual organization (Walters and Rainbird, 2007). The whole point of the approach is to identify optimal solutions that are acceptable to all stakeholders: customers, suppliers, investors, and so on. The need for agile responses to meet the increased expectations of customers results in creating virtual structures that network with each other and using or leveraging the capital investments made by their partners.

Figure 1: Knowledge exchange in a virtual organization (Rothfuss, 2002)

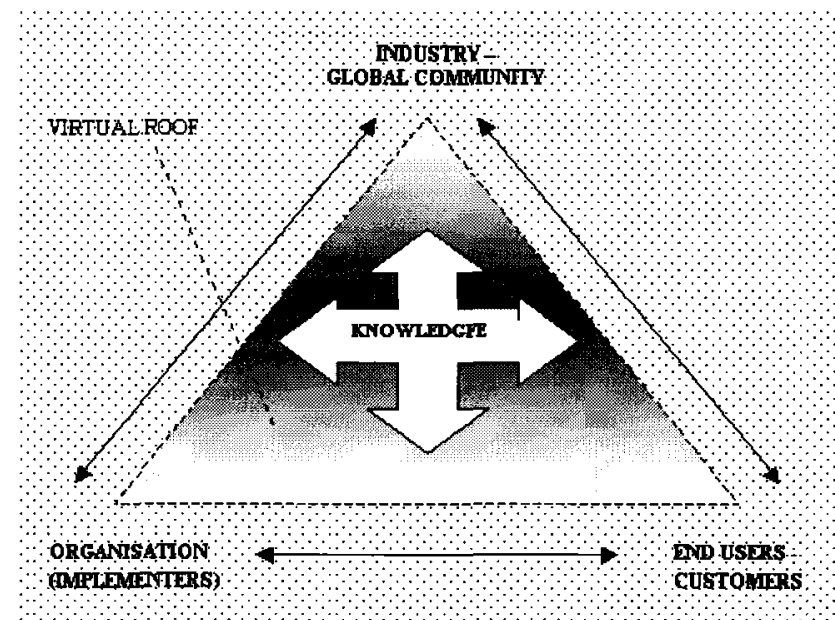

e-Cology Corporation (2003) found that self-sustaining OSS communities rarely emerge spontaneously. Simply releasing software as open source does not guarantee an open 
source community. Proactive effort to form and incubate communities is essential to improve the odds of success. Thus, the OSS companies face a particularly important challenge: to attract enough of the right sort of users early enough to improve the quality and features of their OSS products.

Yang (2005) followed the approach in Bailetti and Callahan (1995) to develop a model that describes the structure an OSS company uses to generate sales from OSS projects. She identified that OSS community management is a key value creation process. As a virtual organization, an OSS company's community should be aware of the structure of the value adding processes within its industry and also its own location within this "structure".

Figure 2 depicts a basic OSS community with the multiple and overlapping roles played by vendors, users, consumers, and volunteers (e-Cology Corporation, 2003).

\section{Figure 2: Basic OSS community}

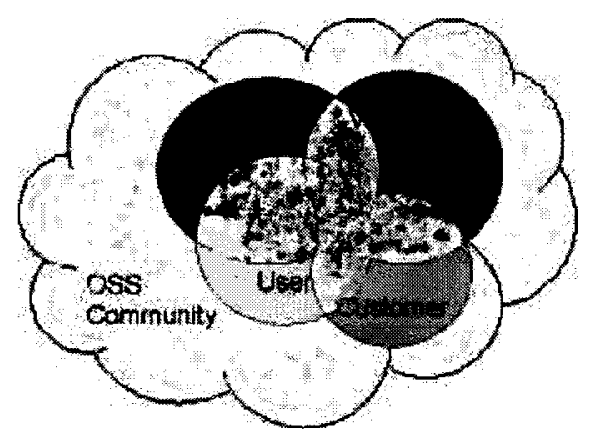

Table 10 presents a summary of the literature on open source communities. 
Table 10: Literature on open source communities

\begin{tabular}{|l|l|}
\hline Study & Highlights \\
\hline von Hippel (2005) & $\begin{array}{l}\text { Innovation communities are defined as nodes consisting of individuals or firms } \\
\text { interconnected by information transfer links which may involve face-to-face, } \\
\text { electronic, or other communication. }\end{array}$ \\
- Innovation communities are often specialized, serving as collection points and \\
repositories for information related to narrow categories of innovations. \\
- Innovation communities offer additional important functions to participants, \\
e.g., chat rooms, email lists, tools. \\
Innovation communities are by no means restricted to the development of OSS.
\end{tabular}




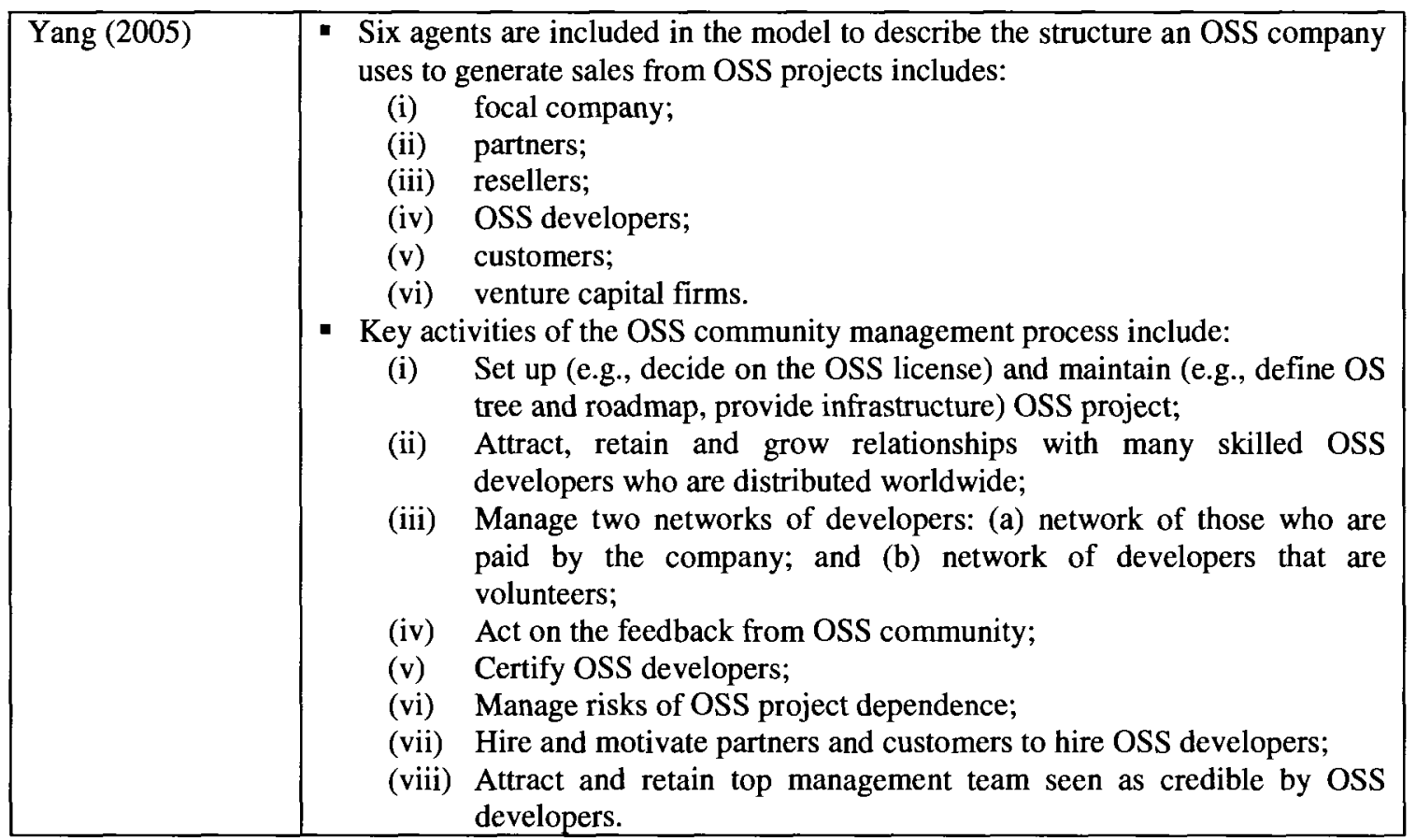

\subsubsection{Relationships between OSS companies and their communities}

OSS companies explicitly try to utilize the resources within their communities in order to create and appropriate value. Dahlander and Magnusson (2005) studied four OSS companies and identified three basic approaches that these companies used to interact with their OSS communities. They also identified a set of managerial challenges a company might encounter along with operational means an OSS company might adopt. Table 11 summarizes their key findings. 
Table 11: Relationships between OSS companies and their communities (Dahlander and Magnusson, 2005)

\begin{tabular}{|c|c|c|c|}
\hline & $\begin{array}{l}\text { Symbiotic (firm gains - } \\
\text { community gains) }\end{array}$ & $\begin{array}{l}\text { Commensalistic (firm } \\
\text { gains - community } \\
\text { indifferent) }\end{array}$ & $\begin{array}{l}\text { Parasitic (firm gains - } \\
\text { community loses) }\end{array}$ \\
\hline $\begin{array}{l}\text { Nature of } \\
\text { relationship }\end{array}$ & $\begin{array}{l}\text { A company gives } \\
\text { something to the } \\
\text { community, which often is } \\
\text { established by the } \\
\text { company. }\end{array}$ & $\begin{array}{l}\text { A company obtains useful } \\
\text { input from the community. }\end{array}$ & $\begin{array}{l}\text { A company obtains useful } \\
\text { inputs from the community, } \\
\text { while does not obey the OSS } \\
\text { values, and rules. }\end{array}$ \\
\hline $\begin{array}{l}\text { Company's } \\
\text { influence on } \\
\text { community }\end{array}$ & High & Low & None \\
\hline $\begin{array}{l}\text { Managerial } \\
\text { challenges }\end{array}$ & $\begin{array}{ll}\text { (i) } & \text { Respecting OSS } \\
& \text { norms and values } \\
\text { (ii) } & \text { Obeying license } \\
\text { (iii) } & \text { Resource } \\
& \text { consumption of } \\
& \text { developing } \\
& \text { community }\end{array}$ & $\begin{array}{l}\text { (i) Respecting OSS } \\
\text { norms and values } \\
\text { (ii) Obeying license } \\
\text { (iii) Getting acceptance of } \\
\text { the community for } \\
\text { using its resources in } \\
\text { commercial } \\
\text { applications }\end{array}$ & (i) Avoiding direct conflicts \\
\hline $\begin{array}{l}\text { Operational } \\
\text { means of } \\
\text { subtle } \\
\text { control }\end{array}$ & 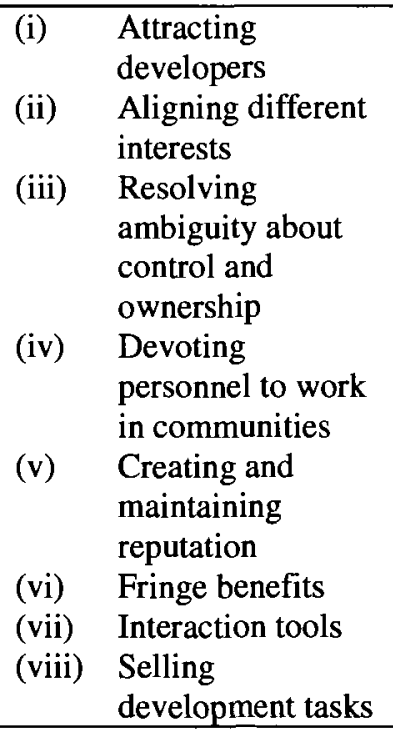 & $\begin{array}{l}\text { (i) Devoting personnel } \\
\text { to work in } \\
\text { community }\end{array}$ & \\
\hline
\end{tabular}

\subsection{Web-based content mining}

\subsubsection{Content analysis of websites}

The advent of universally accessible, ubiquitous organizational websites has provided scholars with an opportunity to apply methods of content analysis (Hicks et al., 2006). Content analyses of corporate websites have been conducted by Ho (1997), Liu, Arnett, 
Capella, and Beatty (1997), and Perry and Bodkin (2000). Recent studies on website communication have focused on how websites are used to build relationships with stakeholders (Kent, Taylor, and White, 2003), how companies present themselves as socially responsible corporate citizens on their websites (Pollach, 2003), and how they use their websites to disclose financial information (Marston, 2003).

Ho (1997) proposed three frameworks for evaluating corporations' websites: (i) promotion of products and services; (ii) provision of data and information; and (iii) processing of business transactions.

Liu et al. (1997) analyzed the content of homepages by looking for a set of features. They identified 14 features: company overview, products and services, what is new, a search function, employment opportunities, interactive feedback, customer assistance, index and directory, financial facts, links to other sites, online business, a guest book, frequently asked questions (FAQs) and messages from the Chief Executive Officer (CEO). They organized these features into five categories: (i) promotion; (ii) provision; (iii) transactions; (iv) communications; and (v) sensationalism.

Most of these researchers' classifications were based upon marketing activity on the websites, not upon online communications. Other studies on content analysis of websites focused on companies and how they built their image and reputations online. Jo and Jung (2005) concluded that public relations seemed to be a significant function of corporate websites even more than traditional advertising or marketing. 
Table 12 presents a summary of the literature on content analysis of websites.

Table 12: Literature on content analysis of websites

\begin{tabular}{|c|c|c|c|c|}
\hline Study & Research purpose & Sample size & $\begin{array}{l}\text { Variables } \\
\text { studied }\end{array}$ & $\begin{array}{l}\text { Analytical } \\
\text { approach }\end{array}$ \\
\hline Ho (1997) & $\begin{array}{l}\text { Evaluate websites from } \\
\text { a customer's } \\
\text { perspective of value- } \\
\text { added }\end{array}$ & $\begin{array}{l}1000 \text { companies } \\
\text { across } 40 \text { industries } \\
\text { in North America }\end{array}$ & $\begin{array}{l}\text { Features or } \\
\text { functions that fit } \\
\text { each of the } \\
\text { purpose-value } \\
\text { combination }\end{array}$ & $\begin{array}{l}\text { A crude measure } \\
\text { of the breadth }\end{array}$ \\
\hline $\begin{array}{l}\text { Jo and Jung } \\
(2005)\end{array}$ & $\begin{array}{l}\text { Compare companies' } \\
\text { websites both in USA } \\
\text { and South Korea to } \\
\text { identify the differences } \\
\text { in terms of a model of } \\
\text { public relations }\end{array}$ & $\begin{array}{l}30 \text { companies in } \\
\text { USA and } 30 \\
\text { companies in South } \\
\text { Korea }\end{array}$ & $\begin{array}{l}\text { Features based } \\
\text { upon a model of } \\
\text { public relations }\end{array}$ & Chi-square test \\
\hline $\begin{array}{l}\text { Kent et al. } \\
(2003)\end{array}$ & $\begin{array}{l}\text { Examine the } \\
\text { relationship between } \\
\text { website design and } \\
\text { organizational } \\
\text { responsiveness to } \\
\text { stakeholder information } \\
\text { needs }\end{array}$ & 150 organizations & $\begin{array}{l}\text { levels of } \\
\text { resource } \\
\text { dependency on } \\
\text { publics }\end{array}$ & Separate $t$ tests \\
\hline $\begin{array}{l}\text { Liu et al. } \\
\text { (1997) }\end{array}$ & $\begin{array}{l}\text { Provide valuable } \\
\text { insight into the future } \\
\text { trends of home page } \\
\text { usage by large business } \\
\text { organizations }\end{array}$ & 322 companies & $\begin{array}{l}\text { Main features of } \\
\text { the home pages }\end{array}$ & $\begin{array}{l}\text { The percentage } \\
\text { distribution of } \\
\text { main content } \\
\text { categories }\end{array}$ \\
\hline $\begin{array}{l}\text { Marston } \\
(2003)\end{array}$ & $\begin{array}{l}\text { Examine the extent of } \\
\text { financial disclosure on } \\
\text { the Internet by leading } \\
\text { Japanese companies }\end{array}$ & $\begin{array}{l}78 \text { companies in } \\
\text { Japan }\end{array}$ & $\begin{array}{l}\text { Capital } \\
\text { employed, } \\
\text { turnover, profit }\end{array}$ & $\begin{array}{l}\text { Kruskal-Wallis } \\
\text { test, and Chi- } \\
\text { square test }\end{array}$ \\
\hline $\begin{array}{l}\text { Perry and } \\
\text { Bodkin (2000) }\end{array}$ & $\begin{array}{l}\text { Indentify differences in } \\
\text { marketing } \\
\text { communications use on } \\
\text { websites across } \\
\text { different firms and } \\
\text { different industries }\end{array}$ & 100 companies & $\begin{array}{l}\text { Product } \\
\text { advertising, } \\
\text { company } \\
\text { specific } \\
\text { advertising, sales } \\
\text { promotion, } \\
\text { public relations, } \\
\text { direct marketing, } \\
\text { etc. }\end{array}$ & $\begin{array}{l}\text { An analysis of } \\
\text { variance } \\
\text { (ANOVA) }\end{array}$ \\
\hline Pollach (2003) & $\begin{array}{l}\text { Explore how companies } \\
\text { communicate their } \\
\text { ethical stance on their } \\
\text { websites }\end{array}$ & 6 companies & $\begin{array}{l}\text { Employee } \\
\text { diversity, } \\
\text { environmental } \\
\text { responsibility, } \\
\text { philanthropy, or } \\
\text { ethics within the } \\
\text { organization }\end{array}$ & $\begin{array}{l}\text { case studies, and } \\
\text { cross-case } \\
\text { analysis }\end{array}$ \\
\hline
\end{tabular}




\subsubsection{Content mining approaches}

Weiss (2005) defined the popularity of an open source project as being proportional to the number of web pages that mention this project success somehow. This popularity can be measured using web search engines to collect online data on several ideas, i.e., objective point of view, relevance, and up-to-date information. He designed a practical experiment to verify four methods of measuring the popularity of open source projects. The experimental results from quantitative analysis on open source projects showed that that backlinks counting and refined backlinks counting seemed to demonstrate relevant and sensible properties.

Hicks et al. (2006) searched for innovative keywords on firms' websites and then found that high-tech strategies can be found on known high-tech small firms but not on the control group. The hit counts for each keyword on each firm's website were obtained and normalized by the size of the website using a Google's Simple Object Access Protocol (SOAP) Application Programming Interface (API). Factor Analysis detected a pattern in use of the keywords and delineated six factors to interpret six high technology commercialization strategies used by small firms. The web searching method presented in their paper holds promise for capturing more than just business strategies, and in some circumstances, can be a cost-effective way to replace surveys and reduce respondent burden.

Table 13 presents a summary of the literature on content mining approaches. 
Table 13: Literature on content mining approaches

\begin{tabular}{|c|c|}
\hline Study & Highlights \\
\hline Weiss (2005) & $\begin{array}{l}\text { Four methods of measuring the popularity of open source projects: } \\
\text { (i) simple word counting: count the number of pages containing words; } \\
\text { (ii) license-reference counting: count the number of pages containing a phrase } \\
\text { required by the project's license; } \\
\text { (iii) backlinks counting: count the number of hypertextual references; } \\
\text { (iv) refined backlinks counting: subtract the total number of pages found in the } \\
\text { project's domain from the total backlink count. }\end{array}$ \\
\hline Hicks et al. (2006) & $\begin{array}{l}\text { - Indentify a set of innovative keywords on firms' websites } \\
\text { - Obtain the number of pages mentioning the keywords } \\
\text { - Normalize the hit counts for each keyword on each firm website by the size of } \\
\text { website } \\
\text { - Finalize a firm-by-keyword matrix } \\
\text { - Use Factor Analysis to detect a pattern in use of the keywords and classify } \\
\text { small high-tech firms }\end{array}$ \\
\hline
\end{tabular}

\subsection{Lessons learned from the literature review}

The following lessons were learned from examining the literature:

\section{Lesson 1: Need to examine the market offers of VC funded OSS startups}

Although several researchers have studied companies' market offers based on OSS (Alam, 2006; Koenig, 2004; Pienaar, 2007), the classification of VC funded OSS startups in terms of their market offers is not known. The ways in which OSS is integrated into companies' market offers have been identified (Alam, 2006). However, the ways VC funded startups integrate OSS into their market offers are not known.

\section{Lesson 2: Articulate the corporate identities from their websites}

The official websites are very powerful vehicles to establish and manage corporate identities (Opoku 2005; Pollach, 2005; Topalian, 2003). Through their websites, organizations speak of three areas: (i) corporate design; (ii) corporate communication; and (iii) corporate behavior. 
Lesson 3: Lack of content analysis research on the websites of OSS companies

Studies of websites focus on how traditional organizations build images, public relations, reputations, and marketing activities. There is a lack of content analysis research on the websites of OSS companies.

\section{Lesson 4: Self-sustaining OSS communities rarely emerge spontaneously}

The OSS community development may be chaotic and unreliable (e-Cology Corporation, 2003). The right conditions must exist for OSS communities to start and grow. Socialsoftware-mediated web applications, such as blogs, make collaboration in OSS communities more convenient (Weber, 2006; von Hippel, 2005).

\section{Lesson 5: Uncertainties in the VC valuation of OSS startups}

It is difficult to finance small technology companies (Callahan and Charbonneau, 2003). Unknown factors affect the present value of OSS startups, and distinctly different elements affect OSS startup evaluation (Puhakka and Jungman, 2005). The business model for OSS still needs to evolve to justify VC investment. 


\section{RESEARCH METHOD}

This chapter has three sections. The first two sections describe the unit of analysis and identify the study period. The third section describes the research method.

\subsection{Unit of analysis}

The unit of analysis is a VC funded startup that sells products and/or services that rely on OSS projects.

\subsection{Study period}

The study period is from January, 2008 to February, 2008. During this period the Google search utility was used to collect the requisite information from the websites of the companies included in the sample.

\subsection{Research method}

The research method used in this research is based on the method used by Hicks et al. (2006). Table 14 provides the steps carried out in this research. 
Table 14: Steps in research method

\begin{tabular}{|ll|l|}
\hline Step & Activity \\
\hline 1. & Get started & - Define research objective \\
\hline 2. & Select sample & $\begin{array}{l}\text { - Set criteria for sample selection } \\
\text { - Identify and verify the websites of OSS startups }\end{array}$ \\
\hline 3. & Collect data & $\begin{array}{l}\text { - Select web pages used to develop keywords } \\
\text { - Identify a list of potentially informative keywords } \\
\text { - Acquire data in terms of the frequency of occurrence of these } \\
\text { keywords on the websites } \\
\text { - Finalize the list of keywords }\end{array}$ \\
\hline 4. & Analyze data & $\begin{array}{l}\text { - Use Factor Analysis to analyze data } \\
\text { - Interpret the factors that emerged from the Factor Analysis }\end{array}$ \\
\hline 5. & Discuss results & $\begin{array}{l}\text { Cluster companies in terms of the factors } \\
\text { - Compare the results with those in the literature }\end{array}$ \\
\hline
\end{tabular}

\subsubsection{Get started}

The objective of this research is to classify VC funded OSS startups using the information on their market offers and businesses that is available online.

\subsubsection{Select sample}

The criteria used to select the sample are:

- The company was established in North America during the period from January 1, 2000 to February 1, 2008.

- The company was funded by one or more VCs.

- The company has no public offering.

- The company is not a subsidiary of a parent company.

- The company provides market offers that rely on one or more OSS projects.

- The company's website has more than ten pages and it is in English. 
A database that includes VC funded OSS startups does not exist. Thus, a database of these firms was compiled using information available online. The Google search utility was used to identify VC funded OSS startups.

The following process was used to create the database:

1) Enter into the Google search utility the following phrases: "open source company", "open source firm", "open source startup", “open source software company", “open source software firm", or "open source software startup".

2) Retrieve pages that fall into two types:

(i) pages that mention the names of an open source company. For example, on the page at http://opensource.sys-con.com/read/268326.htm, Open Source Firm Funambol Announces Bounties for its Community Code Sniper Program, the open source company Funambol was founded.

(ii) pages that mention a list of open source companies. For example, the page at http://1 vc.typepad.com/soaring on ridgelift/2006/08/open source sof.html, Open Source Software Companies, includes the names of 63 open source companies.

3) For each firm identified, use the sample selection criteria to determine whether or not it was an OSS startup. For example, according to the information on the official website, the company Adaptive Planning was founded in the United States in 2003, is not a subsidiary of a parent company, has no public offering, provides products and 
services based on OSS, and the size of its website is more than ten pages. Thus, Adaptive Planning was identified as an OSS startup.

4) For each startup, determine whether or not it was a VC funded OSS startup. To accomplish this task, the researcher:

(i) Entered "VC fund $+<$ the name of the OSS startup >", "venture capital $+<$ the name of the OSS startup>" into the Google search utility. The information on the search results was investigated to determine whether or not the company was a VC funded OSS startup. For example, after entering "VC fund Adaptive Planning" into the Google search utility, the page at http://www.venturedeal.com/News/2008/1/22/Adaptive-Planning-Nets-\$10Million-New-Funding, Adaptive Planning Nets \$10 Million New Funding, indicated that the company, Adaptive Planning, is VC funded.

(ii) Checked the website of each of the OSS startups. The information found on its official websites was investigated to determine whether or not the startup was a VC funded OSS startup. For example, on the official website of Adaptive Planning, the page http://www.adaptiveplanning.com/company/investors.php provides the information on the VC that invested in the company. Thus, the company was deemed to be $\mathrm{VC}$ funded.

If the OSS startup was found to be VC funded, it was included in the sample.

Figure 3 depicts the Google search process for VC funded OSS startups. 
Figure 3: Process used to identify VC backed OSS startups

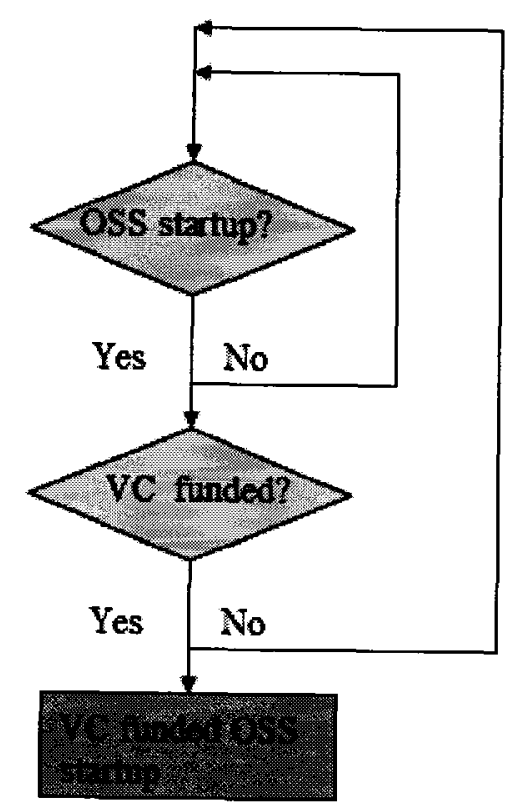

The sources of information that were used included: OSS startup websites, open source websites, online news releases, online industry reports, online academic papers and working papers.

\subsubsection{Collect data}

\section{Keyword development}

A list of keywords was prepared using two steps:

1) A list of potential keywords was compiled.

This set of keywords was identified using the literature on market offers and business activities that rely on OSS (Alam, 2006; Chesbrough and Appleyard, 2007; Hicks et al., 2006; Wallace, 2006). 
2) The list of potential keywords was verified using the information on six OSS startups' websites.

The pages on the startups' websites that were manually examined included:

(i) Introductory page.

(ii) Page that describes product/service portfolio offerings.

(iii) Page that highlights relevant open source projects.

(iv) Page that describes license issues.

(v) Page that describes the startup's community or ecosystem, and partners' involvement.

(vi) Page that describes the firm's historical background and milestones.

To perform the search, Boolean strings consistent with the requirements of the Google search utility were adopted. For instance, Boolean OR must be capitalized; “AND” is assumed; quotation marks are placed around terms to search exact phrases.

\section{Website search and data acquisition}

Data sources are the websites of the VC funded OSS startups included in the sample.

Data was collected as follows:

1) Identify keywords.

2) Identify URLs of the websites of the VC funded OSS startups. 
3) From January to early February 2008, the Google search engine was used to develop a firm-by-keyword matrix. The matrix recorded the frequency of occurrence of each keyword on each company's website.

The total number of pages on the website of a startup was attained by typing " site: the URL of the target startup" into the search box and hitting the 'Enter' key or clicking on the Google Search button. For example, after " site: http://www.coupa.com" was entered into the search utility and 'Enter' was hit, the line of search statistics on the top right of the screen indicated the total number of pages, 42 , as well as the time of how long the search took to complete.

The hit count of each word on each website was obtained by typing the keyword into the search box and hitting the 'Enter' key or clicking on the Google Search button. For example, after "product OR application site: http://www.coupa.com" was entered into the search utility and 'Enter' was hit, the line of search statistics on the right top indicated that 18 pages contained the term "product OR application".

\subsubsection{Analyze data}

The SPSS software was used to analyze the data.

To obtain a measure of frequency that was independent of the size of each company's website, the number of pages mentioning the keywords was normalized by the size of the website (Hicks et al., 2006). For example, for the startup Coupa Software, the hit count of 
the keyword "product OR application" was transformed as follows: $18 / 42=0.43$. The hit count of the keyword was 18 , and the total number of pages of the website was 42 . The raw firm-by-term matrix was transformed into a matrix of firm-by-keyword frequency by dividing the number of hits of a keyword by the total number of pages on the company's website.

Factor Analysis was used to analyze the data. Factor Analysis was chosen over Principal Components Analysis (PCA) because this research seeks to uncover what the underlying factor structure is. PCA is often used for the purposes of scale reduction, not factor exploration (Reise, Waller, and Comrey, 2000; Costello and Osborne, 2005). PCA became common decades ago when computers were slow and expensive to use, and it was a quicker, cheaper alternative to Factor Analysis (Gorsuch, 1990). It is computed without regard to any underlying structure caused by latent variables. In PCA, components are calculated using all of the variance of the manifest variables, and all of that variance appears in the solution (Ford, MacCallum, and Tait, 1986). Factor Analysis was used to extract as many latent factors as necessary to explain the correlations among the keywords. These factors are assumed to be the underlying causes for the intercorrelation between items (Draper, Jennings, and Barón, 2003).

If the data violates conditions of normality, Alpha Extraction was used. Alpha Factor Analysis considers relations in a population of individuals and does not consider the sampling of individuals' problem (Tucker and MacCallum, 1997). Among the choices available for extraction using non-normal variables, Alpha Extraction considers the 
variables in the analysis (keywords in this case) to be a sample from the universe of potential variables (Hicks et al., 2006). The default Varimax Rotation was used to produce an orthogonal set of interpretable dimensions and uncorrelated factors. Factors with eigenvalues greater than 1.0 were retained. Coefficients over 0.40 were displayed and retained.

Keywords were dropped if they had zero variance. Keywords were dropped if they were used infrequently and the value of the Kaiser-Meyer-Olkin Measure of Sampling Adequacy was less than 0.60 (the minimum acceptable value). Keywords were dropped if the value of Kaiser-Meyer-Olkin Measure of Sampling Adequacy increased after they were dropped. 


\section{RESULTS}

This chapter has four sections. The first section describes the sample used in this research. The second presents the descriptive statistics. The third section provides the results of the Factor Analysis. Finally, the fourth section summarizes the results.

\subsection{Sample}

The sample is comprised of $61 \mathrm{VC}$ funded OSS startups. Appendix A provides a list of the companies in the sample. For each company, Appendix A shows the year and the place of founding, and the website address.

Figure 4 provides a bar graph of the VC funded OSS startups in the sample by the year they were founded. Figure 4 shows that more than half of the companies in the sample $(n=43 ; 70.5 \%)$ were established in 2003, 2004 and 2005. All companies in the sample were founded in the United States. 
Figure 4: VC funded OSS startups in the sample categorized by year founded

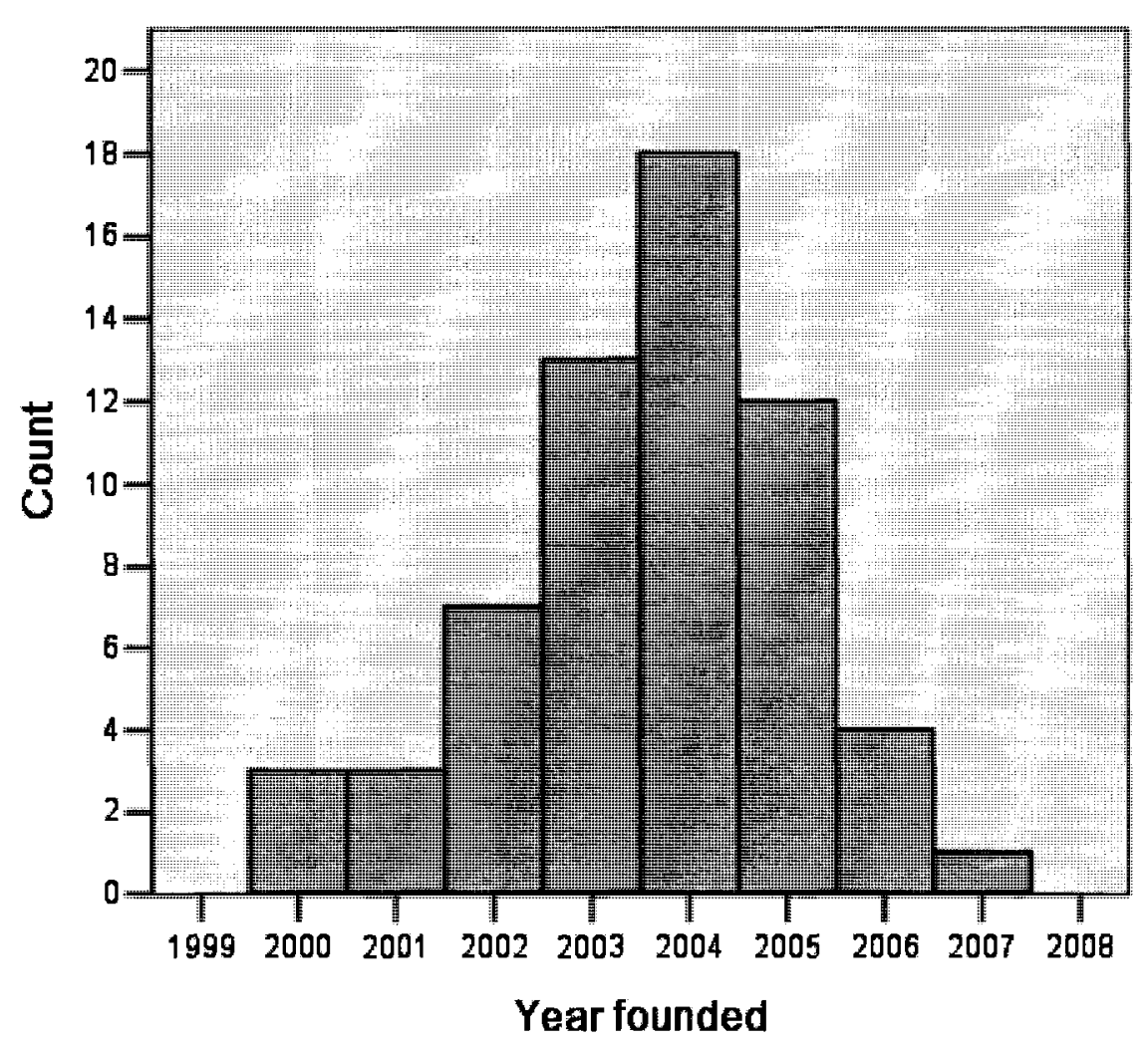

\subsection{Keywords}

To develop the set of keywords, the websites of six OSS startups (Krugle, Palamida, Scalix, Univa UD, Xandros and Zenoss) as well as the literature on market offers and business activities that rely on OSS (Alam, 2006; Chesbrough and Appleyard, 2007; Hicks et al., 2006; Wallace, 2006) were examined.

A total of 45 keywords were identified. 


\subsection{Descriptive statistics}

Table 15 provides the descriptive statistics for the 45 variables that represented the keywords used in this research.

Table 15: Descriptive statistics for the variables representing keywords (sample size $=61$ )

\begin{tabular}{|l|l|c|c|c|c|c|c|}
\hline & Variable & Min & Max & Mean & Std. deviation & Skewness & Kurtosis \\
\hline 1 & $\begin{array}{l}\text { product OR } \\
\text { application }\end{array}$ & 7 & 120,000 & $2,615.18$ & $15,471.838$ & 7.534 & 57.888 \\
\hline 2 & solution & 0 & 36,400 & $1,056.85$ & $5,114.282$ & 6.243 & 40.778 \\
\hline 3 & $\begin{array}{l}\text { product } \\
\text { AND } \\
\text { performance }\end{array}$ & 0 & 7,310 & 190.93 & 943.784 & 7.411 & 56.498 \\
\hline 4 & $\begin{array}{l}\text { service } \\
\text { AND } \\
\text { support }\end{array}$ & 1 & 4,210 & 163.74 & 588.512 & 5.978 & 38.955 \\
\hline 5 & $\begin{array}{l}\text { package OR } \\
\text { packaging }\end{array}$ & 0 & 82,300 & $1,593.82$ & $10,548.679$ & 7.716 & 59.959 \\
\hline 6 & $\begin{array}{l}\text { accessory } \\
\text { OR } \\
\text { accessories }\end{array}$ & 0 & 1,380 & 47.30 & 218.682 & 5.063 & 26.595 \\
\hline 7 & $\begin{array}{l}\text { "open } \\
\text { source" } \\
\text { AND project }\end{array}$ & 0 & $1,720,000$ & $28,747.72$ & $220,176.957$ & 7.807 & 60.971 \\
\hline 8 & project & 0 & $2,190,000$ & $36,811.08$ & $280,318.423$ & 7.807 & 60.967 \\
\hline 9 & $\begin{array}{l}\text { consult OR } \\
\text { consulting }\end{array}$ & 0 & 8,560 & 220.23 & $1,119.356$ & 7.194 & 53.730 \\
\hline 10 & support & 4 & $2,060,000$ & $34,799.89$ & $263,654.021$ & 7.807 & 60.969 \\
\hline 11 & $\begin{array}{l}\text { testing OR } \\
\text { training }\end{array}$ & 0 & 8,690 & 457.77 & $1,602.462$ & 4.381 & 18.458 \\
\hline 12 & $\begin{array}{l}\text { host OR } \\
\text { hosting }\end{array}$ & 0 & 6,610 & 315.80 & $1,226.922$ & 4.538 & 20.103 \\
\hline 13 & subscription & 0 & 10,400 & 208.44 & $1,330.282$ & 7.746 & 60.302 \\
\hline 14 & $\begin{array}{l}\text { "commercial } \\
\text { license" OR } \\
\text { "proprietary } \\
\text { software" }\end{array}$ & 0 & 1,950 & 37.41 & 249.135 & 7.794 & 60.824 \\
\hline 15 & content & 0 & 377,000 & $7,598.07$ & $48,832.671$ & 7.486 & 57.201 \\
\hline 16 & $\begin{array}{l}\text { "compleme- } \\
\text { ntary } \\
\text { content" }\end{array}$ & 0 & 0 & 0.00 & 0.000 &. &. \\
\hline 17 & $\begin{array}{l}\text { incorporate } \\
\text { OR } \\
\text { incorpora- } \\
\text { tion }\end{array}$ & 0 & 4,340 & 80.08 & 555.592 & 7.765 & 60.505 \\
\hline & & & & & & & \\
\hline
\end{tabular}




\begin{tabular}{|c|c|c|c|c|c|c|c|}
\hline 18 & $\begin{array}{l}\text { module OR } \\
\text { modular }\end{array}$ & 0 & 840,000 & $14,654.87$ & $107,639.291$ & 7.766 & 60.517 \\
\hline 19 & $\begin{array}{l}\text { integration } \\
\text { OR integrate } \\
\end{array}$ & 0 & 24,700 & 699.75 & $3,341.066$ & 6.577 & 46.283 \\
\hline 20 & component & 0 & 183,000 & $3,076.33$ & $23,422.425$ & 7.809 & 60.982 \\
\hline 21 & hardware & 1 & 66,400 & $1,221.51$ & $8,495.769$ & 7.779 & 60.656 \\
\hline 22 & $\begin{array}{l}\text { Interoperabi- } \\
\text { lity AND } \\
\text { hardware }\end{array}$ & 0 & 273 & 6.98 & 34.881 & 7.641 & 59.157 \\
\hline 23 & \begin{tabular}{|l|} 
software \\
\end{tabular} & 3 & $2,380,000$ & $39,752.64$ & $304,641.911$ & 7.809 & 60.992 \\
\hline 24 & input & 0 & 478,000 & $8,003.52$ & $61,185.250$ & 7.808 & 60.977 \\
\hline 25 & \begin{tabular}{|l|} 
platform \\
\end{tabular} & 0 & 148,000 & $2,768.36$ & $18,964.918$ & 7.737 & 60.193 \\
\hline 26 & $\begin{array}{l}\text { peripheral } \\
\text { equipment }\end{array}$ & 0 & 5 & 0.18 & 0.695 & 5.889 & 39.560 \\
\hline 27 & $\begin{array}{l}\text { network } \\
\text { infrastruc- } \\
\text { ture }\end{array}$ & 0 & 143 & 22.34 & 33.370 & 1.928 & 2.962 \\
\hline 28 & community & 0 & $1,720,000$ & $29,943.18$ & $220,143.353$ & 7.794 & 60.829 \\
\hline 29 & partner & 1 & 10,100 & 368.00 & $1,458.345$ & 5.682 & 34.989 \\
\hline 30 & $\begin{array}{l}\text { discussion } \\
\text { OR forum }\end{array}$ & 0 & 49,400 & $1,825.84$ & $7,455.735$ & 5.429 & 31.214 \\
\hline 31 & blog & 0 & $1,720,000$ & $29,320.69$ & $220,207.996$ & 7.796 & 60.848 \\
\hline 32 & wiki & 0 & 41,700 & $1,610.02$ & $7,159.059$ & 4.868 & 23.591 \\
\hline 33 & \begin{tabular}{|l|} 
eco OR \\
ecosystem
\end{tabular} & 0 & 604 & 19.00 & 82.258 & 6.511 & 44.861 \\
\hline 34 & \begin{tabular}{|l|} 
"user \\
groups" OR \\
"user group"
\end{tabular} & 0 & 5,700 & 168.25 & 913.215 & 5.526 & 30.058 \\
\hline 35 & \begin{tabular}{|l|} 
"mailing \\
list"
\end{tabular} & 0 & 15,200 & 347.33 & $2,052.737$ & 6.778 & 48.002 \\
\hline 36 & $\begin{array}{l}\text { "tracking } \\
\text { tool" }\end{array}$ & 0 & 179 & 3.07 & 22.911 & 7.800 & 60.890 \\
\hline 37 & \begin{tabular}{|l|} 
org OR \\
organization
\end{tabular} & 1 & $1,720,000$ & $28,785.21$ & $220,159.408$ & 7.809 & 60.985 \\
\hline 38 & delivery & 0 & 24,500 & 489.05 & $3,141.243$ & 7.695 & 59.727 \\
\hline 39 & download & 0 & $1,560,000$ & $29,201.23$ & $200,888.536$ & 7.632 & 58.961 \\
\hline 40 & channel & 0 & 87,700 & $1,557.20$ & $11,231.981$ & 7.771 & 60.574 \\
\hline 41 & \begin{tabular}{|l} 
upgrade OR \\
update
\end{tabular} & 0 & 504,000 & $8,750.51$ & $64,523.822$ & 7.790 & 60.775 \\
\hline 42 & \begin{tabular}{|l|} 
account \\
AND \\
register
\end{tabular} & 0 & 26,100 & 726.67 & $3,835.569$ & 5.890 & 35.754 \\
\hline 43 & $\begin{array}{l}\text { "shopping } \\
\text { cart" }\end{array}$ & 0 & 2,420 & 43.26 & 309.896 & 7.771 & 60.576 \\
\hline 44 & \begin{tabular}{|l|} 
buy OR \\
purchase \\
AND online \\
\end{tabular} & 0 & 5,470 & 130.98 & 705.483 & 7.476 & 57.275 \\
\hline 45 & $\begin{array}{l}\text { login OR } \\
\text { "sign in" }\end{array}$ & 0 & $1,760,000$ & $29,271.54$ & $225,296.995$ & 7.810 & 60.992 \\
\hline
\end{tabular}


Table 16 provides the descriptive statistics for the total number of pages on a firm's website.

Table 16: Descriptive statistics for the total number of pages on the firm's website (sample size $=61)$

\begin{tabular}{|l|c|c|c|c|c|c|}
\hline & Min & Max & Mean & Std. Deviation & Skewness & Kurtosis \\
\hline $\begin{array}{l}\text { Total pages } \\
\text { on the firm's } \\
\text { website }\end{array}$ & 15 & $4,490,000$ & $84,222.20$ & $575,549.600$ & 7.728 & 60.093 \\
\hline
\end{tabular}

To obtain a measure of frequency independent of the size of each firm's website, variables for the keywords were transformed by the number of total pages of the firms' websites (Hicks et al., 2006). The names of these transformed variables were left unchanged.

Table 17 provides the descriptive statistics for the 45 transformed variables for the keywords. 
Table 17: Descriptive statistics for the transformed variables representing keywords

$($ sample size $\mathbf{= 6 1})$

\begin{tabular}{|c|c|c|c|c|c|c|c|}
\hline & $\begin{array}{l}\text { Transformed } \\
\text { variable }\end{array}$ & Min & Max & Mean & $\begin{array}{c}\text { Std. } \\
\text { deviation }\end{array}$ & Skewness & Kurtosis \\
\hline 1 & $\begin{array}{l}\text { product OR } \\
\text { application }\end{array}$ & 0.00 & 0.82 & 0.3708 & 0.21415 & 0.021 & -0.752 \\
\hline 2 & solution & 0.00 & 0.83 & 0.2610 & 0.19107 & 0.722 & 0.242 \\
\hline 3 & $\begin{array}{l}\text { product AND } \\
\text { performance }\end{array}$ & 0.00 & 0.37 & 0.0891 & 0.09537 & 1.589 & 1.866 \\
\hline 4 & $\begin{array}{l}\text { service AND } \\
\text { support }\end{array}$ & 0.00 & 0.73 & 0.1269 & 0.13916 & 2.515 & 7.803 \\
\hline 5 & $\begin{array}{l}\text { package OR } \\
\text { packaging }\end{array}$ & 0.00 & 0.66 & 0.0656 & 0.10969 & 4.308 & 20.184 \\
\hline 6 & $\begin{array}{l}\text { accessory OR } \\
\text { accessories }\end{array}$ & 0.00 & 0.16 & 0.0033 & 0.02028 & 7.712 & 59.926 \\
\hline 7 & $\begin{array}{l}\text { "open source" } \\
\text { AND project }\end{array}$ & 0.00 & 0.53 & 0.1213 & 0.13015 & 1.511 & $1.7 \overline{56}$ \\
\hline 8 & project & 0.00 & 0.61 & 0.1690 & 0.14965 & 1.120 & 0.760 \\
\hline 9 & $\begin{array}{l}\text { consult OR } \\
\text { consulting }\end{array}$ & 0.00 & $0 . \overline{75}$ & 0.0935 & 0.14843 & 2.834 & 8.372 \\
\hline 10 & support & 0.02 & 0.94 & 0.4614 & 0.21156 & 0.076 & -0.159 \\
\hline 11 & $\begin{array}{l}\text { testing OR } \\
\text { training }\end{array}$ & 0.00 & 0.83 & 0.1741 & 0.19032 & 1.646 & 2.518 \\
\hline 12 & $\begin{array}{l}\text { host OR } \\
\text { hosting }\end{array}$ & 0.00 & 0.22 & 0.0432 & 0.04307 & 2.073 & 4.974 \\
\hline 13 & subscription & 0.00 & 0.77 & 0.0549 & 0.10793 & 5.146 & 32.691 \\
\hline 14 & $\begin{array}{l}\text { "commercial } \\
\text { license" OR } \\
\text { "proprietary } \\
\text { software" }\end{array}$ & 0.00 & 0.10 & 0.0140 & 0.02172 & 2.133 & 4.703 \\
\hline 15 & content & 0.00 & 0.94 & 0.1757 & 0.24010 & 2.005 & 3.121 \\
\hline 16 & $\begin{array}{l}\text { "complemen- } \\
\text { tary content" }\end{array}$ & 0.00 & 0.00 & 0.0000 & 0.00000 & & \\
\hline 17 & $\begin{array}{l}\text { incorporate } \\
\text { OR } \\
\text { incorporation }\end{array}$ & 0.00 & 0.07 & 0.0102 & 0.01547 & 2.371 & 5.748 \\
\hline 18 & $\begin{array}{l}\text { module OR } \\
\text { modular }\end{array}$ & 0.00 & 0.29 & 0.0358 & 0.05429 & 2.760 & 8.540 \\
\hline 19 & $\begin{array}{l}\text { integration OR } \\
\text { integrate }\end{array}$ & 0.00 & 0.94 & 0.1840 & 0.21496 & 2.030 & 3.861 \\
\hline 20 & component & 0.00 & 0.44 & 0.0512 & 0.07510 & 3.660 & 15.754 \\
\hline 21 & hardware & 0.00 & 0.56 & 0.1154 & 0.11923 & 1.667 & 3.245 \\
\hline 22 & $\begin{array}{l}\text { Interoperabi- } \\
\text { lity AND } \\
\text { hardware }\end{array}$ & 0.00 & 0.05 & 0.0071 & 0.01118 & 2.174 & 4.733 \\
\hline 23 & software & 0.04 & 0.99 & 0.4595 & 0.25708 & 0.228 & -0.739 \\
\hline 24 & input & 0.00 & 0.40 & 0.0349 & 0.05738 & 4.623 & 26.416 \\
\hline 25 & platform & 0.00 & 0.69 & $0.19 \overline{947}$ & 0.16419 & 1.063 & 0.741 \\
\hline 26 & $\begin{array}{l}\text { peripheral } \\
\text { equipment }\end{array}$ & 0.00 & 0.02 & 0.0007 & 0.00325 & 5.478 & 30.372 \\
\hline
\end{tabular}




\begin{tabular}{|l|l|c|c|c|c|c|c|}
\hline 27 & $\begin{array}{l}\text { network } \\
\text { infrastructure }\end{array}$ & 0.00 & 0.50 & 0.0466 & 0.07945 & 3.829 & 18.648 \\
\hline 28 & community & 0.00 & 0.98 & 0.3690 & 0.30706 & 0.694 & -0.878 \\
\hline 29 & partner & 0.00 & 0.73 & 0.1487 & 0.13412 & 1.855 & 5.282 \\
\hline 30 & $\begin{array}{l}\text { discussion OR } \\
\text { forum }\end{array}$ & 0.00 & 0.91 & 0.1295 & 0.21365 & 2.653 & 6.618 \\
\hline 31 & blog & 0.00 & 0.94 & 0.1748 & 0.27769 & 1.623 & 1.423 \\
\hline 32 & wiki & 0.00 & 0.98 & 0.0528 & 0.14876 & 4.933 & 27.311 \\
\hline 33 & $\begin{array}{l}\text { eco OR } \\
\text { ecosystem }\end{array}$ & 0.00 & 0.07 & 0.0131 & 0.01617 & 1.730 & 2.580 \\
\hline 34 & $\begin{array}{l}\text { "user groups" } \\
\text { OR "user } \\
\text { group" }\end{array}$ & 0.00 & 0.02 & 0.0042 & 0.00603 & 1.533 & 1.618 \\
\hline 35 & "mailing list" & 0.00 & 0.11 & 0.0059 & 0.01557 & 5.978 & 40.935 \\
\hline 36 & "tracking tool" & 0.00 & 0.00 & 0.0001 & 0.00045 & 7.230 & 54.109 \\
\hline 37 & $\begin{array}{l}\text { org OR } \\
\text { organization }\end{array}$ & 0.01 & 0.86 & 0.1693 & 0.17489 & 2.008 & 4.318 \\
\hline 38 & delivery & 0.00 & 0.55 & 0.0513 & 0.07771 & 4.645 & 27.541 \\
\hline 39 & download & 0.00 & 0.83 & 0.2429 & 0.22178 & 1.192 & 0.398 \\
\hline 40 & channel & 0.00 & 0.18 & 0.0345 & 0.03838 & 1.829 & 3.578 \\
\hline 41 & $\begin{array}{l}\text { upgrade OR } \\
\text { update }\end{array}$ & 0.00 & 0.25 & 0.0813 & 0.05698 & 0.887 & 0.241 \\
\hline 42 & $\begin{array}{l}\text { account AND } \\
\text { register }\end{array}$ & 0.00 & 0.13 & 0.0130 & 0.02480 & 3.093 & 10.503 \\
\hline 43 & $\begin{array}{l}\text { "shopping } \\
\text { cart" }\end{array}$ & 0.00 & 0.11 & 0.0040 & 0.01625 & 5.406 & 30.171 \\
\hline 44 & $\begin{array}{l}\text { buy OR } \\
\text { purchase AND } \\
\text { online }\end{array}$ & 0.00 & 0.50 & 0.0355 & 0.07347 & 4.714 & 27.325 \\
\hline 45 & $\begin{array}{l}\text { login OR “sign } \\
\text { in" }\end{array}$ & 0.00 & 0.55 & 0.0958 & 0.13605 & 1.968 & 3.238 \\
\hline & & & & & & \\
\hline
\end{tabular}

Alpha Extraction was used in the Factor Analysis because the data violated conditions of normality.

\subsection{Factor Analysis}

One transformed variable, "complementary content", was dropped because SPSS could not perform the Factor Analysis while it was included.

Six transformed variables were dropped because they were very infrequently used and made the value of the Kaiser-Meyer-Olkin Measure of Sampling Adequacy less than 
0.60. These were: accessory OR accessories, peripheral equipment, "user groups" OR "user group”, “mailing list”, “tracking tool”, and "shopping cart”.

Nineteen transformed variables were dropped because they did not effectively distinguish business operations. The value of the Kaiser-Meyer-Olkin Measure of Sampling Adequacy increased after they were dropped. These variables were related to the following keywords: product AND performance, package OR packaging, project, support, host OR hosting, subscription, incorporate OR incorporation, module OR modular, component, input, network infrastructure, eco OR ecosystem, delivery, channel, upgrade OR update, account AND register, download, buy OR purchase AND online, and login OR “sign in”.

Of the original 45 variables, 19 were used in the Factor Analysis. In this case, the subject (firm) to item (keyword) ratio (61/19) was more than 3. The minimum acceptable value is 2 (Stanek, 1993).

Table 18 presents the commonalities for the 19 variables used in the Factor Analysis. The "initial" commonalities present the percent of variance in a given variable explained by all 19 factors (one per variable). The "extracted" commonalities present the percent of variance in a given variable explained by the factors that are extracted. 
Table 18: Commonalities for the variables used in the Factor Analysis with Alpha

Factoring as the extraction method (sample size $=61$ )

\begin{tabular}{|l|l|c|c|}
\hline NO. & Transformed variable & Initial & Extraction \\
\hline 1 & product OR application & 0.715 & 0.703 \\
\hline 2 & solution & 0.523 & 0.342 \\
\hline 3 & service AND support & 0.460 & 0.458 \\
\hline 4 & "open source" AND project & 0.433 & 0.397 \\
\hline 5 & consult OR consulting & 0.669 & 0.562 \\
\hline 6 & testing OR training & 0.735 & 0.863 \\
\hline 7 & $\begin{array}{l}\text { "commercial license" OR "proprietary } \\
\text { software" }\end{array}$ & 0.456 & 0.350 \\
\hline 8 & integration OR integrate & 0.638 & 0.579 \\
\hline 9 & hardware & 0.464 & 0.514 \\
\hline 10 & software & 0.649 & 0.667 \\
\hline 11 & platform & 0.612 & 0.611 \\
\hline 12 & community & 0.503 & 0.685 \\
\hline 13 & partner & 0.537 & 0.435 \\
\hline 14 & blog & 0.399 & 0.412 \\
\hline 15 & wiki & 0.343 & 0.381 \\
\hline 16 & discussion OR forum & 0.378 & 0.358 \\
\hline 17 & org OR organization & 0.301 & 0.394 \\
\hline 18 & content & 0.376 & 0.407 \\
\hline 19 & interoperability AND hardware & 0.537 & 0.527 \\
\hline
\end{tabular}

Table 19 presents the results of the Kaiser-Meyer-Olkin and Bartlett's Test. The data passed the default Kaiser-Meyer-Olkin Measure of Sampling Adequacy, with a value of 0.686. The minimum acceptable value is 0.60 (Hicks et al., 2006).

Table 19: Kaiser-Meyer-Olkin and Bartlett's test (sample size = 61)

\begin{tabular}{|l|l|c|}
\hline \multicolumn{2}{|l|}{ Kaiser-Meyer-Olkin Measure of Sampling Adequacy } & .686 \\
\hline \multirow{3}{*}{ Bartlett's Test of Sphericity } & Approx. Chi-Square & 432.120 \\
\cline { 2 - 3 } & df & 171 \\
\cline { 2 - 3 } & Sig. & .000 \\
\hline
\end{tabular}

Figure 5 shows that there were five factors with eigenvalues greater than 1.0. 
Figure 5: Scree plot for the VC funded OSS startups (sample size = 61)

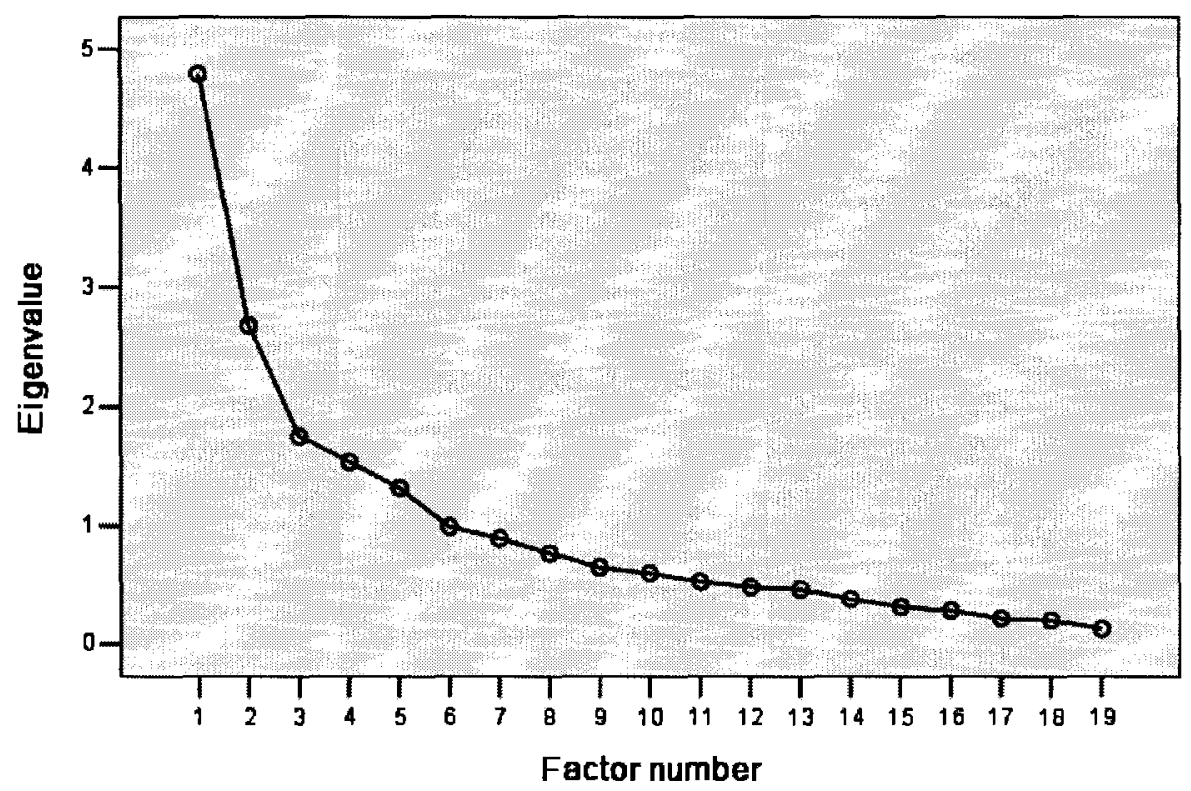

Table 20 shows that $50.7 \%$ of total variance was explained by the five factors with eigenvalue greater than 1 .

Table 20: Total variance explained (sample size $=61$ )

\begin{tabular}{|l|c|c|c|}
\hline Factor & \multicolumn{3}{|c|}{ Rotation sums of squared loadings } \\
\hline & Total & \% of Variance & Cumulative \% \\
\hline 1 & 2.920 & 15.3 & 15.3 \\
\hline 2 & 2.835 & 14.9 & 30.2 \\
\hline 3 & 1.419 & 7.5 & 37.7 \\
\hline 4 & 1.286 & 6.8 & 44.5 \\
\hline 5 & 1.184 & 6.2 & 50.7 \\
\hline
\end{tabular}

Table 21 provides the results of the five factor solution. Table 21 shows the variables with factor loadings that were greater than 0.4 . 
Table 21: Results of Factor Analysis (sample size = 61)

\begin{tabular}{|c|c|c|c|c|c|c|}
\hline \multirow[t]{2}{*}{ Interpretation } & \multirow{2}{*}{$\begin{array}{l}\text { Transformed } \\
\text { variable }\end{array}$} & \multicolumn{5}{|c|}{ Factor } \\
\hline & & $\mathbf{1}$ & 2 & 3 & 4 & 5 \\
\hline \multirow{6}{*}{$\begin{array}{l}\text { Factor } 1 \\
\text { Sell products } \\
\text { or applications } \\
\text { that integrate } \\
\text { OSS with } \\
\text { proprietary } \\
\text { software or } \\
\text { hardware }\end{array}$} & 10. software & .738 & & & & \\
\hline & $\begin{array}{l}\text { 19. interoperability } \\
\text { AND hardware }\end{array}$ & .704 & & & & \\
\hline & 11. platform & .659 & & & & \\
\hline & 9. hardware & .634 & & & & \\
\hline & $\begin{array}{ll}1 . & \begin{array}{l}\text { product OR } \\
\text { application }\end{array}\end{array}$ & .627 & .419 & & & \\
\hline & 2. solution & .492 & & & & \\
\hline \multirow{4}{*}{$\begin{array}{l}\text { Factor } 2 \\
\text { Provide } \\
\text { consulting, } \\
\text { training or } \\
\text { testing services } \\
\text { anchored } \\
\text { around OSS }\end{array}$} & $\begin{array}{ll}6 . & \begin{array}{l}\text { testing OR } \\
\text { training }\end{array} \\
\end{array}$ & & .922 & & & \\
\hline & $\begin{array}{|ll|}5 . & \text { consult OR } \\
\text { consulting }\end{array}$ & & .717 & & & \\
\hline & $\begin{array}{ll}8 . & \text { integration OR } \\
\text { integrate }\end{array}$ & & .640 & & & \\
\hline & 13. partner & & .524 & & & \\
\hline \multirow{4}{*}{$\begin{array}{l}\text { Factor } 3 \\
\text { Provide } \\
\text { support } \\
\text { services and } \\
\text { commercial } \\
\text { licenses based } \\
\text { on OSS } \\
\text { projects }\end{array}$} & $\begin{array}{ll}17 . & \text { org OR } \\
& \text { organization } \\
\end{array}$ & & & .603 & & \\
\hline & $\begin{array}{l}\text { 4. "open source" } \\
\text { AND project }\end{array}$ & & & .549 & & \\
\hline & $\begin{array}{ll}\text { 3. } & \begin{array}{l}\text { service AND } \\
\text { support }\end{array} \\
\end{array}$ & & & .477 & & \\
\hline & $\begin{array}{l}\text { 7. "commercial } \\
\text { license" OR } \\
\text { "proprietary } \\
\text { software" }\end{array}$ & & & .413 & & \\
\hline \multirow{2}{*}{$\begin{array}{l}\text { Factor } 4 \\
\text { Community } \\
\text { development } \\
\text { through blog } \\
\text { and wiki }\end{array}$} & 14. blog & & & & .633 & \\
\hline & 15. wiki & & & & .584 & \\
\hline \multirow{2}{*}{$\begin{array}{l}\text { Factor } 5 \\
\text { Community } \\
\text { development } \\
\text { through } \\
\text { forums }\end{array}$} & 12. community & & & & & .721 \\
\hline & $\begin{array}{ll}\text { 16. } & \text { discussion OR } \\
\text { forum }\end{array}$ & & & & & .572 \\
\hline
\end{tabular}

Rotated Factor Matrix

Extraction Method: Alpha Factoring

Rotation Method: Varimax with Kaiser Normalization

Rotation converged in 7 iterations 
The solution appears to be a good solution. There are three factors with more than three items loading strongly, i.e., 0.50 or greater. They are the markers of a solid factor (Costello and Osborne, 2005).

\subsection{Summary of the results applied to the 61 VC funded OSS startups}

For each company in the sample, Appendix B shows the company's market offers and ways it supports community development. The 61 VC funded OSS startups were organized and coded in Table 18 in terms of the results of the Factor Analysis. For example, Devicescape integrated OSS with hardware to create security applications for Wi-Fi devices (code denoted 1), and also had a community forum to enable developers to post questions and participate in discussions with other community members (code denoted 5). Thus, the company was coded as 15 .

Table 22 provides the codes for each of the 61 companies in the sample. A Y in a cell included in the first three columns in Table 22 indicates that the researcher examined Appendix B and found that the company has a market offer related to Factors 1, 2 or 3. Similarly, a $\mathrm{Y}$ in a cell included in the last two columns in Table 22 indicates that the researcher examined Appendix B and found that the company supports community development using methods associated with Factors 4 or 5. 
Table 22: Identification and classification of the $61 \mathrm{VC}$ funded startups

\begin{tabular}{|c|c|c|c|c|c|c|c|}
\hline & Company & Factor 1 & Factor 2 & Factor 3 & Factor 4 & Factor 5 & Code \\
\hline 1 & $\begin{array}{l}\text { ActiveGrid } \\
\text { (WaveMaker) }\end{array}$ & & & $\mathrm{Y}$ & & $\mathrm{Y}$ & 35 \\
\hline 2 & $\begin{array}{l}\text { Adaptive } \\
\text { Planning }\end{array}$ & & $\mathrm{Y}$ & $\bar{Y}$ & & $\mathrm{Y}$ & 235 \\
\hline 3 & Alfresco & & $\mathrm{Y}$ & $\mathrm{Y}$ & $\mathrm{YY}$ & $\mathbf{Y}$ & 2345 \\
\hline 4 & Appscio & $\mathrm{Y}$ & & & & & 1 \\
\hline 5 & Astaro & $\mathrm{Y}$ & & & & & 1 \\
\hline 6 & Automattic & & $\mathrm{Y}$ & & $\mathrm{Y}$ & $\mathrm{Y}$ & 245 \\
\hline 7 & $\begin{array}{l}\text { Barracuda } \\
\text { Networks }\end{array}$ & $\mathrm{Y}$ & & & & $\bar{Y}$ & 15 \\
\hline 8 & BitTorrent & $\bar{Y}$ & $\mathrm{Y}$ & & & & 12 \\
\hline 9 & $\begin{array}{l}\text { Black Duck } \\
\text { Software }\end{array}$ & & $\mathrm{Y}$ & & & & 2 \\
\hline 10 & Centeris & & & $\mathrm{Y}$ & & $\mathrm{Y}$ & 35 \\
\hline 11 & CIGNEX & & $\mathrm{Y}$ & & & $\mathrm{Y}$ & 25 \\
\hline 12 & Cleversafe & $\bar{Y}$ & $\mathrm{Y}$ & & & $\bar{Y}$ & 125 \\
\hline 13 & Coupa Software & & & $\bar{Y}$ & & $\bar{Y}$ & 35 \\
\hline 14 & $\begin{array}{l}\text { Collaborative } \\
\text { Software } \\
\text { Initiative } \\
\end{array}$ & & $\bar{Y}$ & & & & 2 \\
\hline 15 & Continuent & & $\mathrm{Y}$ & $\mathrm{Y}$ & & $\mathrm{Y}$ & 235 \\
\hline 16 & db4objects & $\mathrm{Y}$ & & $\bar{Y}$ & & $\bar{Y}$ & 135 \\
\hline 17 & Devicescape & $\mathrm{Y}$ & & & & $\bar{Y}$ & 15 \\
\hline 18 & EnterpriseDB & & & $\bar{Y}$ & & $\mathrm{Y}$ & 35 \\
\hline 19 & FiveRuns & & & $\mathrm{Y}$ & & & 3 \\
\hline 20 & Fonality & $\mathrm{Y}$ & & & & & 1 \\
\hline 21 & Funambol & $\mathrm{Y}$ & & $\mathrm{Y}$ & $\mathrm{Y}$ & $\mathrm{Y}$ & 1345 \\
\hline 22 & Greenplum & & $\mathrm{Y}$ & $\mathrm{Y}$ & & $\mathrm{Y}$ & 235 \\
\hline 23 & $\begin{array}{l}\text { GroundWork } \\
\text { Open Source }\end{array}$ & & $Y$ & $\mathrm{Y}$ & & $\mathrm{Y}$ & 235 \\
\hline 24 & Hyperic & & $\mathrm{Y}$ & $\mathrm{Y}$ & & $\mathrm{Y}$ & 235 \\
\hline 25 & JasperSoft & & $\mathrm{Y}$ & $\mathrm{Y}$ & & $\mathrm{Y}$ & 235 \\
\hline 26 & Koders & $\mathrm{Y}$ & $\mathrm{Y}$ & & & $\mathrm{Y}$ & 125 \\
\hline 27 & Krugle* & $\mathrm{Y}$ & $\mathrm{Y}$ & & & & 125 \\
\hline 28 & Laszlo Systems & & $\mathrm{Y}$ & $\mathrm{Y}$ & & $\mathrm{Y}$ & 235 \\
\hline 29 & LucidEra & & & $\mathrm{Y}$ & & & 3 \\
\hline 30 & MedSphere & $\mathrm{Y}$ & & $\mathrm{Y}$ & & & 13 \\
\hline 31 & MuleSource & & $\mathrm{Y}$ & $\mathrm{Y}$ & & $\bar{Y}$ & 235 \\
\hline 32 & OpenClovis & $\mathrm{Y}$ & $\mathrm{Y}$ & & $\mathrm{Y}$ & $\mathrm{Y}$ & 1235 \\
\hline 33 & Open-Xchange & & $\mathrm{Y}$ & $\mathrm{Y}$ & $\mathrm{Y}$ & $\mathrm{Y}$ & 2345 \\
\hline 34 & Optaros & & $\mathrm{Y}$ & & & & 2 \\
\hline
\end{tabular}




\begin{tabular}{|c|c|c|c|c|c|c|c|}
\hline 35 & Palamida* & & $\mathrm{Y}$ & & & & 2 \\
\hline 36 & Pentaho & & $\mathrm{Y}$ & & $\mathrm{Y}$ & $Y$ & 245 \\
\hline 37 & PostPath & $\mathrm{Y}$ & & $\mathrm{Y}$ & & & 13 \\
\hline 38 & Qlusters & $\mathrm{Y}$ & & $\mathrm{Y}$ & & & 13 \\
\hline 39 & rPath & & $\mathrm{Y}$ & & $Y$ & $\mathrm{Y}$ & 245 \\
\hline 40 & Scalix* & & $\mathrm{Y}$ & $\mathrm{Y}$ & $\mathrm{Y}$ & $\mathrm{Y}$ & 2345 \\
\hline 41 & SiCortex & $\mathrm{Y}$ & & & & & 1 \\
\hline 42 & SIPphone & $\mathrm{Y}$ & & & & & 1 \\
\hline 43 & Socialtext & $\mathrm{Y}$ & & $\mathrm{Y}$ & $Y$ & & 134 \\
\hline 44 & SourceLabs & & $\mathrm{Y}$ & $\mathrm{Y}$ & & $\mathrm{Y}$ & 235 \\
\hline 45 & SpikeSource & & $\mathrm{Y}$ & $\mathrm{Y}$ & & $\mathrm{Y}$ & 235 \\
\hline 46 & Splunk & & $\mathrm{Y}$ & $\mathrm{Y}$ & & $\mathrm{Y}$ & 235 \\
\hline 47 & SugarCRM & & $\mathrm{Y}$ & $\mathrm{Y}$ & $\mathrm{Y}$ & $\mathrm{Y}$ & 2345 \\
\hline 48 & Talend & & $\mathrm{Y}$ & $\mathrm{Y}$ & $Y$ & $\mathrm{Y}$ & 2345 \\
\hline 49 & Terracotta & & $\mathrm{Y}$ & $\mathrm{Y}$ & $\mathrm{Y}$ & $\mathrm{Y}$ & 2345 \\
\hline 50 & Terascala & $\mathrm{Y}$ & & & & & 1 \\
\hline 51 & $\begin{array}{l}\text { Transera } \\
\text { Communications }\end{array}$ & $\mathrm{Y}$ & & & & & 1 \\
\hline 52 & Univa UD* & & $\mathrm{Y}$ & $\mathrm{Y}$ & $\mathrm{Y}$ & $\mathrm{Y}$ & 2345 \\
\hline 53 & Untangle & $\mathrm{Y}$ & & $\mathrm{Y}$ & $Y$ & $\mathrm{Y}$ & 1345 \\
\hline 54 & VirtualLogix & $\mathrm{Y}$ & $\mathrm{Y}$ & & & & 12 \\
\hline 55 & VirtualIron & & & $\mathrm{Y}$ & & & 3 \\
\hline 56 & Vyatta & $\mathrm{Y}$ & $\mathrm{Y}$ & & & $\mathrm{Y}$ & 125 \\
\hline 57 & Wikia & & $Y$ & & $Y$ & $Y$ & 245 \\
\hline 58 & WS02 & & $\mathrm{Y}$ & & $\mathrm{Y}$ & $\mathrm{Y}$ & 245 \\
\hline 59 & Xandros* & & & $\mathrm{Y}$ & & & 3 \\
\hline 60 & Zenoss* & & $Y$ & $\mathrm{Y}$ & $\mathrm{Y}$ & $Y$ & 2345 \\
\hline 61 & Zmanda & & $\mathrm{Y}$ & $\mathrm{Y}$ & $\mathrm{Y}$ & $\mathrm{Y}$ & 2345 \\
\hline
\end{tabular}

Table 23 provides the count of the companies that have the same code. For example, there were 11 companies with code 235 . This means that 11 companies had market offers that relate to Factors 2 and 3, and a way to support the community that relates to Factor 5. 
Table 23: Number of companies by code

\begin{tabular}{|c|c|c|c|}
\hline Code & Description of the code & $\begin{array}{l}\text { Number of } \\
\text { companies }\end{array}$ & Percent \\
\hline 1 & $\begin{array}{l}\text { Sell products or applications that } \\
\text { integrate OSS with proprietary software } \\
\text { or hardware }\end{array}$ & 7 & $11.5 \%$ \\
\hline 2 & $\begin{array}{l}\text { Provide consulting, training or testing } \\
\text { services anchored around OSS }\end{array}$ & 4 & $6.6 \%$ \\
\hline 3 & $\begin{array}{l}\text { Provide support services and } \\
\text { commercial licenses based on OSS } \\
\text { projects }\end{array}$ & 4 & $6.6 \%$ \\
\hline 4 & $\begin{array}{l}\text { Community development through blog } \\
\text { and wiki }\end{array}$ & 0 & 0 \\
\hline 5 & $\begin{array}{l}\text { Community development through } \\
\text { forums }\end{array}$ & 0 & 0 \\
\hline 12 & $\begin{array}{l}\text { Sell products or applications that } \\
\text { integrate OSS with proprietary software } \\
\text { or hardware; provide consulting, } \\
\text { training or testing services anchored } \\
\text { around OSS }\end{array}$ & 2 & $3.3 \%$ \\
\hline 13 & $\begin{array}{l}\text { Sell products or applications that } \\
\text { integrate OSS with proprietary software } \\
\text { or hardware; provide support services } \\
\text { and commercial licenses based on OSS } \\
\text { projects }\end{array}$ & 3 & $4.9 \%$ \\
\hline 15 & $\begin{array}{l}\text { Sell products or applications that } \\
\text { integrate OSS with proprietary software } \\
\text { or hardware; community development } \\
\text { through forums }\end{array}$ & 2 & $3.3 \%$ \\
\hline 25 & $\begin{array}{l}\text { Provide consulting, training or testing } \\
\text { services anchored around OSS; } \\
\text { community development through } \\
\text { forums }\end{array}$ & 1 & $1.6 \%$ \\
\hline 35 & $\begin{array}{l}\text { Provide support services and } \\
\text { commercial licenses based on OSS } \\
\text { projects; community development } \\
\text { through forums }\end{array}$ & 4 & $6.6 \%$ \\
\hline 125 & $\begin{array}{l}\text { Sell products or applications that } \\
\text { integrate OSS with proprietary software } \\
\text { or hardware; provide consulting, } \\
\text { training or testing services anchored } \\
\text { around OSS; community development } \\
\text { through forums }\end{array}$ & 4 & $6.6 \%$ \\
\hline
\end{tabular}




\begin{tabular}{|c|c|c|c|}
\hline 134 & $\begin{array}{l}\text { Sell products or applications that } \\
\text { integrate OSS with proprietary software } \\
\text { or hardware; provide support services } \\
\text { and commercial licenses based on OSS } \\
\text { projects; community development } \\
\text { through blog and wiki }\end{array}$ & 1 & $1.6 \%$ \\
\hline 135 & $\begin{array}{l}\text { Sell products or applications that } \\
\text { integrate OSS with proprietary software } \\
\text { or hardware; provide support services } \\
\text { and commercial licenses based on OSS } \\
\text { projects; community development } \\
\text { through forums }\end{array}$ & 1 & $1.6 \%$ \\
\hline 235 & $\begin{array}{l}\text { Provide consulting, training or testing } \\
\text { services anchored around OSS; provide } \\
\text { support services and commercial } \\
\text { licenses based on OSS projects; } \\
\text { community development through } \\
\text { forums }\end{array}$ & 11 & $18 \%$ \\
\hline 245 & $\begin{array}{l}\text { Provide consulting, training or testing } \\
\text { services anchored around OSS; } \\
\text { community development through blog } \\
\text { and wiki; community development } \\
\text { through forums }\end{array}$ & 5 & $8.2 \%$ \\
\hline 1235 & $\begin{array}{l}\text { Sell products or applications that } \\
\text { integrate OSS with proprietary software } \\
\text { or hardware; provide consulting, } \\
\text { training or testing services anchored } \\
\text { around OSS; provide support services } \\
\text { and commercial licenses based on OSS } \\
\text { projects; community development } \\
\text { through forums }\end{array}$ & 1 & $1.6 \%$ \\
\hline 1345 & $\begin{array}{l}\text { Sell products or applications that } \\
\text { integrate OSS with proprietary software } \\
\text { or hardware; provide support services } \\
\text { and commercial licenses based on OSS } \\
\text { projects; community development } \\
\text { through blog, wiki, and forums }\end{array}$ & 2 & $3.3 \%$ \\
\hline 2345 & $\begin{array}{l}\text { Provide consulting, training or testing } \\
\text { services anchored around OSS; provide } \\
\text { support services and commercial } \\
\text { licenses based on OSS projects; } \\
\text { community development through blog, } \\
\text { wiki, and forums }\end{array}$ & 9 & $14.7 \%$ \\
\hline Total & & 61 & $100 \%$ \\
\hline
\end{tabular}




\section{DISCUSSION OF RESULTS}

This chapter has four sections. The first section interprets the factors that emerged from the Factor Analysis. The second section uses a diagram that shows company clusters determined by the codes shown in Table 23. The third section compares the results from this research with those in the literature. The fourth section discusses the importance of wiki, blog and forums to community development.

\subsection{Interpreting the factors}

Five significant factors (i.e., eigenvalues $>1.0$ ) emerged from the Factor Analysis performed on the publicly available data on $61 \mathrm{VC}$ funded startups. Table 24 provides the researcher's interpretation of what the five factors mean and the rationales for them. The results suggest that: (i) Factors 1,2 and 3 refer to market offers of VC funded OSS startups; and (ii) Factors 4 and 5 refer to community development. 
Table 24: Interpretation of the five factors

\begin{tabular}{|c|c|c|}
\hline Factor & Factor represents & Rationale \\
\hline 1 & $\begin{array}{l}\text { Products or applications that integrate OSS } \\
\text { with proprietary software or hardware. }\end{array}$ & $\begin{array}{l}\text { Companies use OSS to provide lower cost } \\
\text { solutions to customers and prototype market } \\
\text { offers to attain a fit between their products and } \\
\text { customer needs. } \\
\text { OSS enables customers to switch platforms } \\
\text { reducing vendor lock-in. }\end{array}$ \\
\hline 2 & $\begin{array}{l}\text { Consulting, training or testing services } \\
\text { anchored around OSS. } \\
\text { Consulting services include design, } \\
\text { installation, configuration, deployment, } \\
\text { maintenance, systems integration and } \\
\text { enhancement, migration, tutorials, and } \\
\text { documentation. }\end{array}$ & $\begin{array}{l}\text { Partners help companies prototype market offers } \\
\text { and access new markets. }\end{array}$ \\
\hline 3 & $\begin{array}{l}\text { Support services and commercial licenses } \\
\text { based on OSS projects. } \\
\text { Support services include fixes to the } \\
\text { software, advice and suggestions for } \\
\text { deploying the software in customers' } \\
\text { environment, and customized development. }\end{array}$ & $\begin{array}{l}\text { Companies create a software stack to integrate } \\
\text { OSS or add advanced functionalities in order to } \\
\text { develop commercial licenses. }\end{array}$ \\
\hline 4 & $\begin{array}{l}\text { Community development through content } \\
\text { exchange. }\end{array}$ & $\begin{array}{l}\text { Companies provide content in blogs and wikis to } \\
\text { support products and applications as well as } \\
\text { communication facilities for users to exchange } \\
\text { ideas about product features, functionalities, } \\
\text { benefits, documentation, questions, and incident } \\
\text { reports. } \\
\text { Blogs and wikis are used to provide information } \\
\text { on products or applications. }\end{array}$ \\
\hline 5 & $\begin{array}{l}\text { Community development through } \\
\text { communication. }\end{array}$ & $\begin{array}{l}\text { Companies use forums to encourage registered } \\
\text { users to contribute to the OSS projects upon } \\
\text { which their products rely. } \\
\text { Forum registration gives users access to } \\
\text { additional features not available to guest users } \\
\text { such as definable avatar images, private } \\
\text { messaging, and ability to communicate via } \\
\text { email. }\end{array}$ \\
\hline
\end{tabular}

\subsection{Company clusters}

Figure 6 shows the companies in the sample organized in clusters using the codes shown

in Table 23. The first number on the top of the box refers to the code in Table 23. The 
number in brackets to the right shows the number of companies in the cluster. The names of the companies in a cluster are included in the bottom part of the box.

Figure 6: VC funded OSS startups grouped using the codes in Table 23 (sample size = 61)

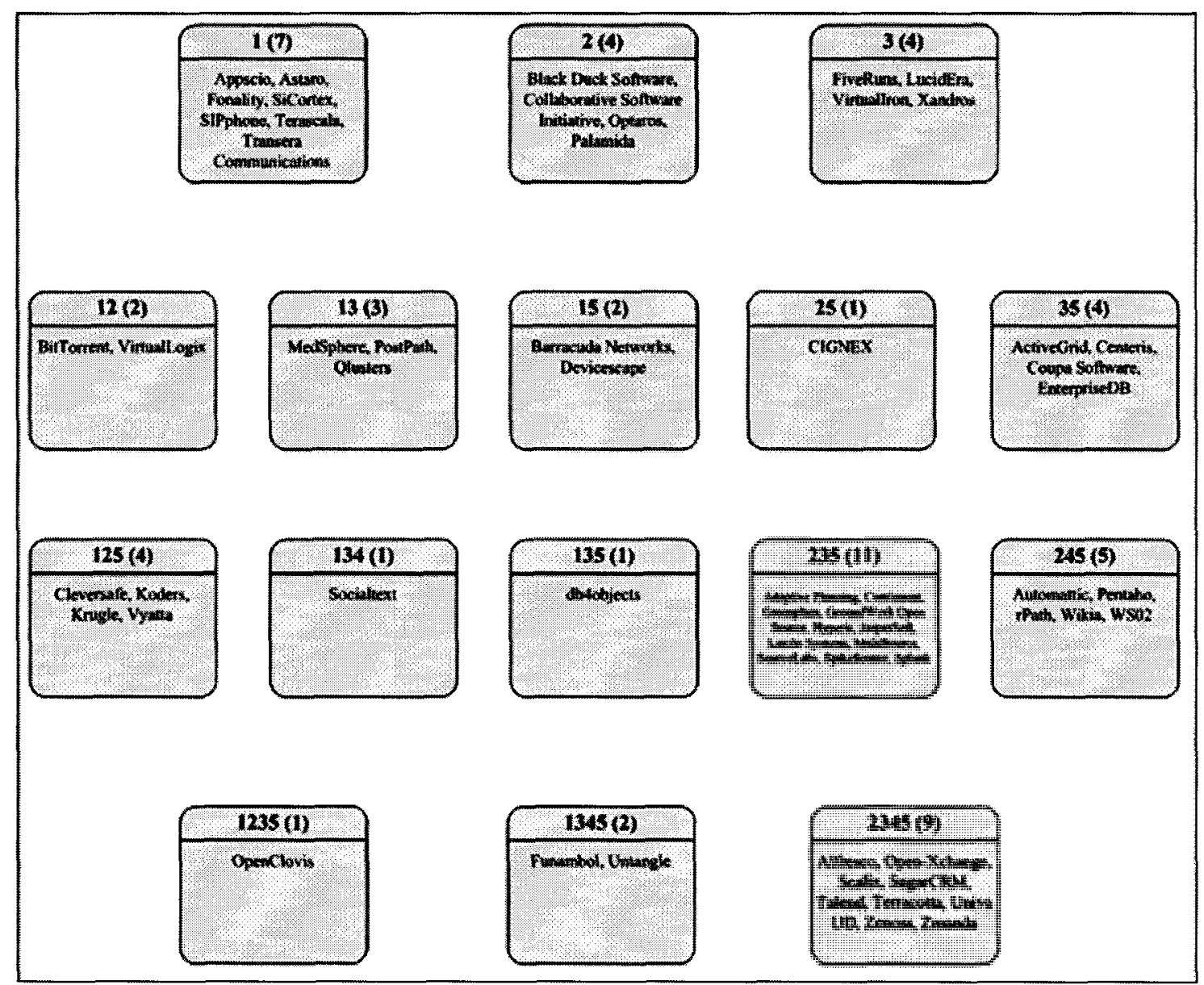

Twenty of the 61 companies in the sample (33\%) (i) sell consulting, training and testing services; (ii) support services and commercial licenses; and (iii) provide community support. These 20 companies are included in the two clusters denoted 235 and 2345. 
Twenty three of the 61 companies in the sample (38\%) sell products and applications. Only seven of these companies ( $11 \%$ of the sample) do not sell services or develop communities while 16 do ( $27 \%$ of the sample). The seven companies that solely sell products and applications are included in the cluster denoted 1. Companies that sell products and applications also include those that: (i) sell services (five companies in clusters denoted 12 and 13); (ii) provide communication support (two companies in cluster denoted 15); (iii) sell consulting, training or testing services and develop communities through communications (four companies in cluster denoted 125); (iv) sell support services and commercial licenses as well as develop communities through content exchange (one company in cluster denoted 134); (v) sell support services and commercial licenses as well as develop communities with communication utilities (one company in cluster denoted 135); (vi) sell consulting, training or testing services, and services and commercial licenses as well as develop communities with communication utilities (one company in cluster denoted 1235); and (vii) sell support services and commercial licenses as well as develop communities through content exchange and communication (two companies in cluster denoted 1345).

Figure 6 indicates that clusters 4 and 5 do not exist. This means that VCs do not fund startups that solely provide community development.

Of the 61 companies in the sample, 52 sell services (85\%). These companies are included in the clusters denoted $2,3,12,13,25,35,125,134,135,235,245,1235,1345$, and 2345 in Figure 6. 
Of the 52 companies that sell services, 41 also provide community development (79\%). These companies include those in clusters denoted $15,25,35,125,134,135,235,245$, 1235,1345 , and 2345 .

\subsection{Comparison with Alam's results}

Alam (2006) examined a sample of 24 OSS market offers and organized them into six types: (i) hosting and content services; (ii) training and testing services; (iii) support services; (iv) subscription services; (v) commercial licenses; and (vi) products/applications.

Factors 1, 2 and 3 shown in Table 21 refer to four types of market offers identified by Alam (2006): (i) products/applications; (ii) training and testing services; (iii) support services; and (iv) commercial licenses. Support services are often sold simultaneously with commercial licenses. These two types of market offers load on Factor 3.

Companies in Alam's sample provided hosting and content services, as well as subscription services. The results of the Factor Analysis did not identify these two types of market offers. This suggests that both of them are not mainstream market offers for VC funded OSS startups.

Table 25 identifies the types of market offers identified by Alam (2006) were obviously found in this research and what types were not obviously found. 
Table 25: Comparing the results of the Factor Analysis with the market offers identified by Alam (2006)

\begin{tabular}{|l|l|}
\hline $\begin{array}{l}\text { Identified by both Alam (2006) and results of the } \\
\text { Factor Analysis }\end{array}$ & $\begin{array}{l}\text { Identified by Alam (2006) and not by the } \\
\text { results of the Factor Analysis }\end{array}$ \\
\hline - Factor 1: Products or applications & - Hosting and content services \\
- Factor 2: Consulting, training and testing services & - Subscription services \\
- Factor 3: Support services and commercial licenses & \\
\hline
\end{tabular}

Alam (2006) grouped the ways OSS is integrated into market offers into four cells: Minimal-No, Minimal-Yes, Comprehensive-No, and Comprehensive-No. The results of this research suggest that Factor 1 falls into the Comprehensive-Yes cell. This means that OSS is tightly integrated with proprietary assets to create the market offers, and OSS contributes significantly to the firm's market offers.

Factors 2 and 3 fall into the Minimal-Yes cell, where OSS is minimally integrated with the proprietary assets of the firm and OSS contributes significantly to the value of the market offers.

Table 26 identifies the links between the results of the Factor Analysis and the results identified by Alam (2006). 
Table 26: Comparing the results of the Factor Analysis with the ways to integrate

OSS identified by Alam (2006)

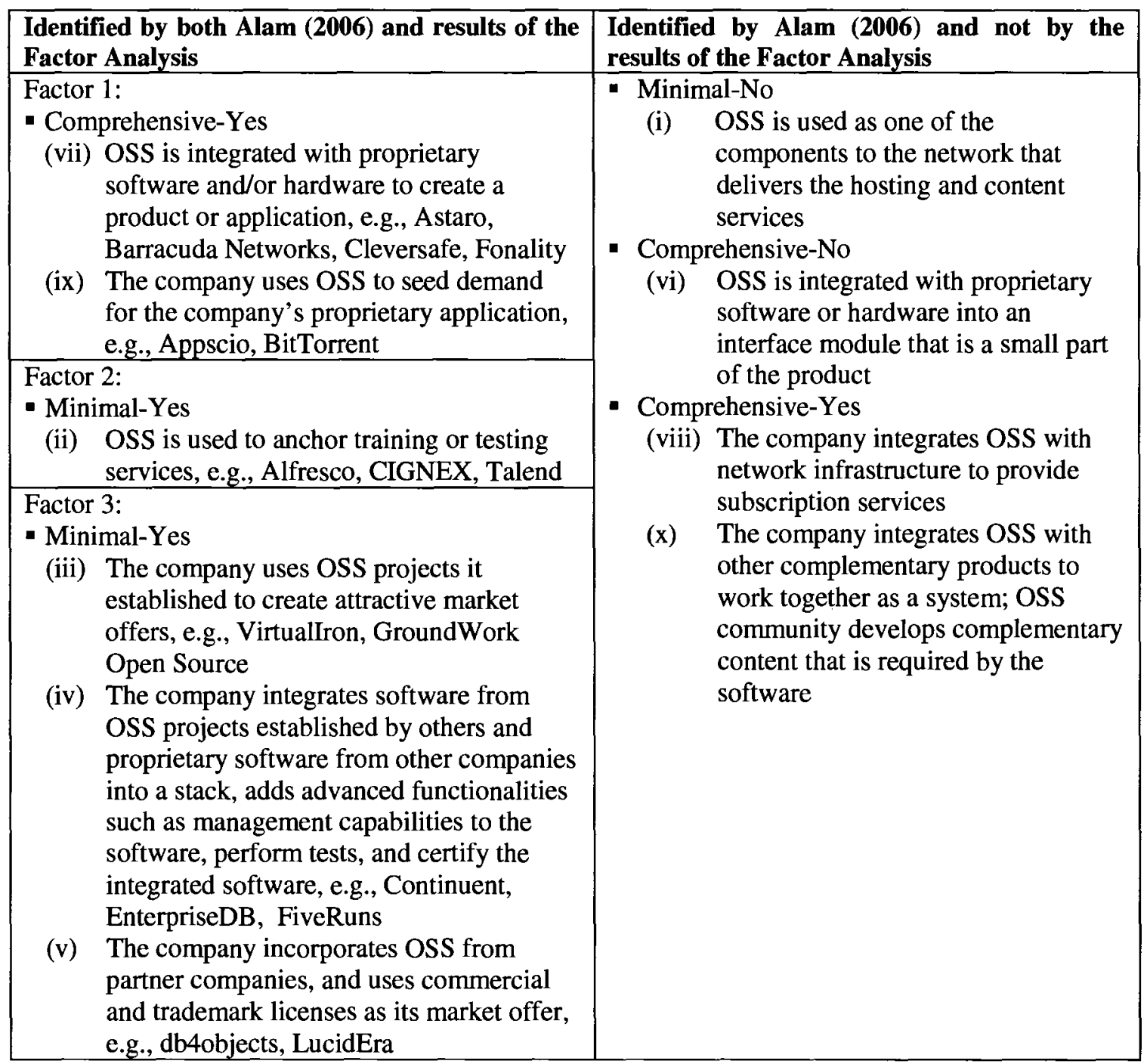

The results of this research suggest that no matter how extensive OSS was integrated with the proprietary assets (comprehensive or minimal) OSS contributed significantly to the market offers of the VC funded startups.

The results of this research also suggest that VC funded OSS startups rarely sold content services, and did not tend to integrate OSS with proprietary software or hardware into an 
interface module, create infrastructures that provide extra added services and functionalities, or integrates OSS with other complementary products to work together as a system.

\subsection{Importance of wiki, blog and forums to community development}

This research finds that Factors 4 and 5 refer to community development through content exchange and communication. By using wikis, blogs and forums the OSS companies can create and transfer community values (Fitzgerald, 2006) to themselves and their customers.

Wikis, blogs and forums are important for five reasons. First, they lower the cost of software development. Wikis, blogs and forums enable the close-to-costless information flow within the community (Bitzer, Schrettl, and Schröder, 2007). This is a key characteristic of the open source development process. Information about new or ongoing OSS projects, feature requests, functionalities, benefits, documentation, questions, incident reports, bug reports and bug fixes is compiled on wikis, blogs and forums to support the distribution of code, and facilitate technology transfer within the community.

Second, wikis, blogs, and forums reduce the cost and risk for customers. Wikis, blogs and forums help customers reduce deployment, maintenance and support costs by simplifying application access to seek and utilize diverse internal and external information sources. They also reduce transaction risks by providing transparent information about the 
contracts for buyers and sellers, and making customers feel secure when adopting open source products.

Third, wikis, blogs and forums help companies build their brands. Wikis, blogs and forums enable companies to increase customers' loyalty for their products.

Fourth, wikis, blogs and forums help companies increase their market share. They help companies create marketplaces for add-ons, support, and other related products and services. They also contribute to making it more difficult for competitors to enter the market.

Fifth, web analytics tools attached to wikis, blogs and forums can help indentify trends relevant to the company. Web analytics on wikis, blogs and forums can help indentify trends in the activities of users, customers, and developers.

\subsection{Firm age}

Figure 4 shows that $70.5 \%$ of the VC funded OSS companies in the sample are three to five years old. This suggests that VCs are not as interested in funding OSS companies that are lees than three years old and over five years old.

Sample selection criteria used in this research required firms to be not older than eight years. This is consistent with the literature. Sauermann and Cohen (2008) indicated that firm age used to define startups is less than six years. Taymaz and Köksal (2006) took 
seven years as the acceptable age for startups. Ghobros (2006) used eight years as the acceptable age for software startups.

\subsection{Why more services than products}

The results of this research find that a greater number of VC funded OSS startups sell services than products and applications. Two reasons may explain this finding. First, when the product or technology becomes a commodity the value to the customer moves up the value chain. Thus, for many VC funded companies to compete effectively they must sell high quality services.

The second reason that OSS companies that sell services may be attractive to VCs is the fact that they do not have to fund expensive $R \& D$ programs. The rate of return on the investment in these companies is higher and the time-to-cash is decreased. 


\section{CONCLUSIONS, LIMITATIONS, AND FUTURE RESEARCH}

This chapter has three sections. The first section describes the conclusions drawn from this research. The second section identifies the limitations of this research. Finally, the third section provides suggestions for future research.

\subsection{Conclusions}

This research uses a data mining process to classify $61 \mathrm{VC}$ funded OSS startups using the information about their market offers and business activities published on their websites.

The main conclusions that can be drawn from this research are:

1. VC funded OSS startups seek to concurrently add value to their customers as well as the communities anchored around the OSS projects and customers on which their market offers rely.

2. The market offers of VC funded OSS startups can be categorized into three groups: (i) products and applications; (ii) consulting, training and testing services; and (iii) commercial licenses and support.

3. A greater number of VC funded OSS startups sell services than products and applications. Most startups that sell products or applications, also sell services. VCs are funding OSS startups for reasons other than their R\&D capability.

4. Community growth is important to the market offers of VC funded OSS startups. VC funded OSS startups depend on the support of the developer community. 
5. Factors 1,2 and 3 refer to four of the six types of market offers identified by Alam (2006): (i) products and applications; (ii) training and testing services; (iii) support services; and (iv) commercial licenses.

6. This research also supports Alam's (2006) classification of the ways companies integrate OSS into market offers. Factor 1 falls into the cell of ComprehensiveYes, and includes two ways in which OSS is integrated into market offers: (i) OSS is integrated with proprietary software and hardware to create a product or application; and (ii) the company uses OSS to seed demand for the company's proprietary application. This research finds that Factors 2 and 3 fall into the cell of Minimal-Yes, and include four ways in which OSS is integrated into market offers: (i) OSS is used to anchor training or testing services; (ii) the company uses OSS projects it established to create attractive market offers; (iii) the company integrates software from OSS projects established by others and proprietary software from other companies to add advanced functionalities; and (iv) the company incorporates OSS from partner companies, and uses commercial and trademark licenses as its market offer.

\subsection{Limitations}

The first limitation is that this research relies on secondary sources of data, e.g., information on companies' websites. This approach is limited because it can not be used to assess topics such as executives' motivations. 
The second limitation is that the results of this research depend on the predefined keywords. A different set of keywords may lead to different results.

The third limitation is that this research only included VC funded OSS startups established in the United States. It is difficult to generalize the results reported in the thesis to VC funded OSS startups in regions outside of the United States.

\subsection{Suggestions for future research}

There are five suggestions for future research. First, future studies can examine the relationship between the market offers of VC funded OSS startups and the size of the developer community by testing hypotheses. These hypotheses may examine the relationship between the number of developers that contribute to an OSS project and the number of companies that sell products and services that rely on the OSS.

Second, researchers can compare market offers across different geographical areas.

Third, future research may use case studies to examine how VC funded companies create, appropriate, and expand value.

Fourth, researchers can classify VC firms that invest in OSS using the method used in this research. 
Fifth, OSS companies can be classified using cluster analysis instead of the method used in this research and the results obtained can be compared. 


\section{REFERENCES}

Alam, R. 2006. Open source software projects, market offers, and competitive advantage. M.Eng Thesis, Department of Systems and Computer Engineering, Carleton University, Ottawa, Canada.

Almeida, P., Dokko, G., and Rosenkopf, L. 2003. Startup size and the mechanisms of external learning: increasing opportunity and decreasing ability? Research Policy, 32(2): 301-315.

Anderson, J.C., Carpenter, G.S., and Narus, J.A. 2001. Managing market offerings in business markets. Kellogg on marketing. New York: John Wiley \& Sons Inc., 330-365.

Aslett, M. 2007. Money for nothing? Open source VC funding. Computer Business Review (CBR). Working Paper. Available at:

http://www.cbronline.com/article_cbr.asp?guid=783E7A58-EC19-40D8-8791-

0B091E2E0B0B. (retrieved Jan. 2, 2008)

Aslett, M. 2008. VC funding for open source hits an all-time high. Available at: http://blogs.the451 group.com/opensource/2008/04/01/vc-funding-for-open-source-hitsan-all-time-high/. (retrieved May 26, 2008)

Bailetti, A.J., and Callahan, J.R. 1995. Managing consistency between product development and public standards evolution. Research Policy, 24: 913-931.

Balmer, J.M.T. 2001. Corporate identity, corporate branding and corporate marketing seeing through the fog. European Journal of Marketing, 35(3/4): 248-291.

Balmer, J.M.T., and Soenen, G.B. 1999. The ACID test of corporate identity management. Journal of Marketing Management, 15(1-3): 69-92.

Benkler, Y. 2006. The wealth of networks: how social production transforms markets and freedom. New Haven, Connecticut: Yale University Press.

Berthon, P., Pitt, L.F., and Watson, R.T. 1996. Marketing communication and the World Wide Web. Business Horizon, 39(5): 24-32.

Birkigt, K., and Stadler, M. 1986. Corporate identity, grundiagen, funktionen und beispoelen. Landsberg am Lech: Verlag Moderne Industrie.

Bitzer, J., Schrettl, W., and Schröder, P. 2007. Intrinsic motivation in open source software development. Journal of Comparative Economics, 35(1): 160-169.

Blau, J. 2006. Open source start-ups speak out. IDG News Service. Available at: http://www.infoworld.com/article/06/11/09/HNstartupsspeakout_1.html. (retrieved Jan. 2, 2008) 
Byfield, B. 2008. VCs regain interest in open source. Available at: http://www.linux.com/feature/128106. (retrieved May 26, 2008)

Callahan, J., and Charbonneau, K. 2003. The role of venture capital in building technology companies in the Ottawa region. Working Paper, Carleton University. Available at: http://http-server.carleton.ca/ callahan/building1.1.pdf. (retrieved May 12, 2007)

Callahan, J., and Muegge, S. 2003. Venture capital's role in innovation: issues, research and stakeholder interests. In L.V. Shavinina (Ed.), The International Handbook on Innovation. New York: Elsevier Science.

Callow, D., and Larsen, M. 2003. Understanding valuation: a venture investor's perspective. Whitepaper of Boston Millennia Partners. Available at:

http://www.millenniapartners.com/_documents/WhitePaper/WhitePaperAttachment6.pdf. (retrieved Jan. 7, 2008)

Chesbrough, H., and Appleyard, M. 2007. Open innovation and strategy. California Management Review, 50(1): 57-76.

Chun, R., and Davies, G. 2001. E-reputation: the role of mission and vision statements in positioning strategy. Brand Management, 8(4-5): 315-333.

Cook, J. 2005. Venture capital: open source startups are hot - too hot? Working Paper. Available at: http://seattlepi.nwsource.com/venture/241908_vc23.html. (retrieved Jan. 2, 2008)

Costello, A., and Osborne J. 2005. Best practices in Exploratory Factor Analysis: four recommendations for getting the most from your analysis. Practical Assessment, Research \& Evaluation, 10(7): 1-9.

Dafermos, G. 2001. Management and virtual decentralized networks: the Linux project. First Monday, Working Paper, 6(11). Available at:

http://firstmonday.org/issues/issue6_11/dafermos/index.html. (retrieved Dec. 26, 2007)

Dahlander, L., and Magnusson, M. 2005. Relationship between open source software companies and communities: observation from Nordic companies. Research Policy, 34: 481-493.

Draper, M., Jennings, J., and Barón, A. 2003. Factor analysis and concurrent validity of a university counseling center presenting problems checklist. A Research Report of the Research Consortium of Counseling \& Psychological Services in Higher Education. Available at: http://www.utexas.edu/student/cmhc/research/FactorAnalysis.pdf. (retrieved Jan. 22, 2008) 
e-Cology Corporation. 2003. OSS in Canada. Working Paper. Available at:

http://www.e-cology.ca/canfloss/report/CANfloss_Report.pdf. (retrieved Dec. 26, 2007)

Fisher, R., Oyelere, P., and Laswad, F. 2004. Corporate reporting on the Internet: audit issues and content analysis of practices. Managerial Auditing, 19(3): 412-439.

Ford, J.K., MacCallum, R.C., and Tait, M. 1986. The application of Exploratory FactorAnalysis in Applied Psychology - a critical review and analysis. Personnel Psychology, 39(2): 291-314.

Fitzgerald, B. 2006. The transformation of open source software. MIS Quarterly, 30(3): 587-598. Available at: http://www.idi.ntnu.no/ ericm/brian.misq.pdf. (retrieved May 20, 2008)

Ghobros, M. 2006. The relationship between capability platform and performance for software startups. M.Eng Thesis, Department of Systems and Computer Engineering, Carleton University, Ottawa, Canada.

Gorsuch, R.L. 1990. Common factor analysis versus component analysis - some well and little known facts. Multivariate Behavioral Research, 25(1): 33-39.

Haapanen, A. 2007. Open source in venture capital transactions. Proceedings of COSS the Finnish Centre for Open Source Solutions. Available at:

http://www.coss.fi:8888/c/document_library/get_file?folderId=34\&name=DLFE-99.pdf. (retrieved Jan. 7, 2008)

Hertel, G., Niedner, S., and Herrmann, S. 2003. Motivation of software developers in open source projects: an internet-based survey of contributors to the Linux kernel. Research Policy, 32: 1159-1177.

Hicks, D., Libaers, D., Porter, A., and Schoeneck, D. 2006. Identification of the technology commercialization strategies of high-tech small firms. Small Business Research Summary, No. 289. Available at:

http://www.sba.gov/advo/research/rs289tot.pdf. (retrieved Jul. 6, 2007)

Himanen, P. 2001. The hacker ethic and the spirit of the information age. New York: Random House.

Ho, J. 1997. Evaluating the World Wide Web: a global study on commercial sites. Journal of Computer Mediated Communication, 3(1), June. Available at: http://jcmc.indiana.edu/vol3/issue 1/ho.html. (retrieved May 28, 2008)

Jo, S., and Jung, J. 2005. A cross-cultural study of the World Wide Web and public relations. Corporate Communication: An International Journal, 10(1): 24-40. 
Kent, M.L., Taylor, M., and White, W.J. 2003. The relationships between web site design and organizational responsiveness to stakeholders. Public Relations Review, 29(1): 63-77.

Koenig, J. 2004. Seven open source business strategies for competitive advantage. IT Managers Journal. May 14. Available at:

http://www.riseforth.com/pdfs/Seven-Open-Source-Business-Strategies-JCK.pdf.

(retrieved Aug. 8, 2008)

Kotler, P., and Turner, R. 1995. Managing products, lines, brands, and packaging, marketing management - analysis, planning, implementation, and control. Prentice Hall Canada. 420-449.

Lakhani, K.R., and von Hippel, E. 2003. How open source software works: "Free" userto-user assistance. Research Policy, 32: 923-943.

LaMonica, M. 2005. Open source, open wallet. CENT news. Available at:

http://www.news.com/Open-source,-open-wallet/2100-7344_3-5934144.html. (retrieved Jan. 7, 2008)

Lerner, J., and Tirole, J. 2002. Some simple economics of open source. Journal of Industrial Economics, 52: 197-234.

Lerner, J., and Tirole, J. 2005. The scope of open source licensing. Journal of Law, Economics, and Organization, 21(1): 20-56.

Levitt, T. 1980. Marketing success through differentiation - of anything. Harvard Business Review, January-February (58): 83-91.

Liu, C., Arnett, K. P., Capella, L. M., and Beatty, R.C. 1997. Web sites of the Fortune 500 companies: facing customers through home pages. Information \& Management, 31(6): 335-345.

Marston, C. 2003. Financial reporting on the Internet by leading Japanese companies. Corporate Communications: An International Journal, 8(1): 23-34.

Maynard, M., and Tian, Y. 2004. Between global and glocal: content analysis of the Chinese web sites of the 100 top global brands. Public Relations Review, 30: 285-291.

Opoku, R.A. 2005. Communication of brand personality by some top business schools online. Licentiate thesis, Lulea University of Technology, Lulea, Sweden. Available at: http://epubl.ltu.se/1402-1757/2005/53/LTU-LIC-0553-SE.pdf. (retrieved Jan. 7, 2008)

Perry M., and Bodkin, C. 2000. Content analysis of Fortune 100 company web sites. Corporate Communications: an International Journal, 5(2): 87-96. 
Pienaar, M. 2007. Open source service - a us industry perspective. Proceedings of COSS - the Finnish Centre for Open Source Solutions. Available at:

http://www.coss.fi:8888/c/document_library/get_file?folderId=33\&name=DLFE-92.pdf. (retrieved Jan. 7, 2008)

Pollach, I. 2003. Communicating corporate ethics on the World Wide Web. Business \& Society, 42(2): 277-87.

Pollach, I. 2005. Corporate self-presentation on the WWW: strategies for enhancing usability, credibility and utility. Corporate Communications: An International Journal, 10(4): 285-301.

Puhakka, M., and Jungman, H. 2005. Evaluation and valuation of open source software companies: a venture capitalist' perspective. Frontiers of E-business Research 2005, Working Paper. Available at: http://www.ebrc.fi/kuvat/855-865_05.pdf. (retrieved Jan. 2, 2008)

Raymond, E. 2001. The Cathedral and the Bazaar: musings on Linux and open source by an accidental revolutionary. Sebastopol, California: O'Reilly Media, Inc.

Reise, S.P., Waller, N.G., and Comrey, A.L. 2000. Factor analysis and scale revision. Psychological Assessment, 12: 287-297.

Roblimo, R. 2006. Open source venture capitalist answers your questions. Available at: http://interviews.slashdot.org/article.pl?sid=06/10/13/1451242. (retrieved Dec. 26, 2007)

Rothfuss, G. 2002. A framework for open source projects. Master Thesis in Computer Science, Department of Information Technology, University of Zurich, Zurich, Switzerland. Available at: http://greg.abstrakt.ch/docs/OSP_framework.pdf. (retrieved Aug. 8, 2007)

Sauermann, H., and Cohen, W.M. 2008. I don't work for money: the motives of scientists and engineers. Working Paper. Available at:

http://www.law.berkeley.edu/institutes/bclt/entrepreneurship/presentations/Friday/830am /sauermann.pdf. (retrieved Jul. 17, 2008)

Schmidt, C. 1995. The quest for identity. London: Cassell.

Sullivan, J. 1999. What are the functions of corporate home pages? Journal of World Business, 34(2): 193-210.

Stanek, D.M. 1993. Modeling perceptions and preference of home-based and centerbased telecommuting. M.Sc Thesis, Department of Civil and Environmental Engineering, University of California, Davis, USA. Available at:

http://www.its.ucdavis.edu/telecom/r11/factan.html. (retrieved Feb.1, 2008) 
Sterne, P, and Herring, N. 2006. The open source venture capital universe. Available at: http://opensource.sys-con.com/read/209227.htm. (Retrieved May 26, 2008)

Taymaz, E., and Köksal M.Y. 2006. Entrepreneurship, start-up size and selection: why do small entrepreneurs fail? Working Paper, Piacenza Seminar, October 11, 2006. Available at:

http://www3.unicatt.it/unicattolica/dipartimenti/dises/allegati/PiacenzaTaymaz2006.pdf. (retrieved Jul. 17, 2008)

Topalian, A. 2003. The development of corporate identity in the digital era. European Journal of Marketing, 37(7/8): 1119-1132.

Tucker, L., and MacCallum, R. 1997. Exploratory factor analysis. Working Paper. Available at: http://www.unc.edu/ rcm/book/factor.pdf. (retrieved Feb. 6, 2008)

Ueda, M. 2006. A model of open source software style R\&D on business. Proceedings of the International Conference on Software Engineering Advances, 46 - 46.

von Hippel, E., and von Krogh, G. 2003. Open source software and the "privatecollective" innovation model: issues for organization science. Organization Science. 14(2): 209-223.

von Hippel, E. 2005. Democratizing innovation. Cambridge, Massachusetts: MIT Press. Available at: http://web.mit.edu/evhippel/www/democ1.htm. (retrieved Aug. 9, 2007)

Wallace, G. 2006. Open source: changing the enterprise software supply chain for good. Working Paper. Available at: http://linux.sys-con.com/read/173425.htm. (retrieved Jan. 7, 2008)

Walters, D., and Rainbird, M. 2007. Cooperative innovation: a value chain approach. Journal of Enterprise Information Management, 20(5): 595-607.

Weber, D. 2006. Open source marketing. Master Thesis, International Marketing Management, Berlin School of Economics, Berlin, German. Available at:

http://doritweber.files.wordpress.com/2007/11/opensourcemarketing.pdf. (retrieved Jan. $7,2008)$

Weiss, D. 2005. Measuring success of open source projects using web search engines. Working Paper. Available at:

http://www.cs.put.poznan.pl/dweiss/site/publications/download/oss2005-dweiss-projectspopularity.pdf. (retrieved Jul. 9, 2007)

West, J. 2003. How open is open enough? Melding proprietary and open source platform strategies. Research Policy, 32(7): 1259-1285. 
West, J., and Gallagher, S. 2006. Challenges of open innovation: the paradox of firm investment in open source software. R\&D Management, 36(3): 319-331.

Wood, D. 2005, Open source software strategies for venture-funded startups. Working Paper. Available at: http://www.itee.uq.edu.au/ dwood/papers/DW_OSS_Strategies.pdf. (retrieved Jan. 2, 2008)

Yang, J. 2005. Sales generated using open source software projects. M.Eng Thesis, Department of Systems and Computer Engineering, Carleton University, Ottawa, Canada. 


\section{APPENDICES}

\section{Appendix A: List of the $61 \mathrm{VC}$ funded OSS startups included in the sample}

\begin{tabular}{|c|c|c|c|c|}
\hline & Company name & $\begin{array}{l}\text { Year } \\
\text { founded }\end{array}$ & Place founded & Website \\
\hline 1 & $\begin{array}{l}\text { ActiveGrid } \\
\text { (WaveMaker) }\end{array}$ & 2003 & $\begin{array}{l}\text { San Francisco, CA } \\
\text { 94105, USA }\end{array}$ & www.wavemaker.com \\
\hline 2 & Adaptive Planning & 2003 & $\begin{array}{l}\text { Mountain View, CA } \\
\text { 94040, USA }\end{array}$ & www.adaptiveplanning.com \\
\hline 3 & Alfresco & 2005 & $\begin{array}{l}\text { Palo Alto, CA 94301, } \\
\text { USA }\end{array}$ & www.alfresco.com \\
\hline 4 & Appscio & 2006 & $\begin{array}{l}\text { Sunnyvale, CA } \\
94085, \text { USA }\end{array}$ & appscio.com \\
\hline 5 & Astaro & 2000 & $\begin{array}{l}\text { Burlington, MA } \\
01803 \text {, USA }\end{array}$ & www.astaro.com \\
\hline 6 & Automattic & 2005 & $\begin{array}{l}\text { San Francisco, CA } \\
94105, \text { USA }\end{array}$ & automattic.com \\
\hline 7 & Barracuda Networks & 2002 & $\begin{array}{l}\text { Campbell, CA 95008, } \\
\text { USA }\end{array}$ & www.barracudanetworks.com \\
\hline 8 & BitTorrent & 2004 & $\begin{array}{l}\text { San Francisco, CA } \\
94105, \text { USA }\end{array}$ & www.bittorrent.com \\
\hline 9 & Black Duck Software & 2002 & $\begin{array}{l}\text { Waltham, MA 02451, } \\
\text { USA }\end{array}$ & www.blackducksoftware.com \\
\hline 10 & Centeris & 2004 & $\begin{array}{l}\text { Bellevue, WA 98007, } \\
\text { USA }\end{array}$ & www.centeris.com \\
\hline 11 & CIGNEX & 2000 & $\begin{array}{l}\text { Santa Clara, CA } \\
\text { 95054, USA }\end{array}$ & www.cignex.com \\
\hline 12 & Cleversafe & 2004 & Chicago, IL 60616 & www.cleversafe.com \\
\hline 13 & Coupa Software & 2006 & $\begin{array}{l}\text { Foster City, CA } \\
94404, \text { USA }\end{array}$ & www.coupa.com \\
\hline 14 & $\begin{array}{l}\text { Collaborative } \\
\text { Software Initiative }\end{array}$ & 2007 & $\begin{array}{l}\text { Portland, OR 97239, } \\
\text { USA }\end{array}$ & www.csinitiative.com \\
\hline 15 & Continuent & 2004 & San Jose, CA 95128 & www.continuent.com \\
\hline 16 & db4objects & 2004 & San Mateo, CA 94403 & www.db4o.com \\
\hline 17 & Devicescape & 2001 & San Bruno, CA 94066 & www.devicescape.com \\
\hline 18 & EnterpriseDB & 2004 & $\begin{array}{l}\text { Edison, NJ 08837- } \\
2210, \text { USA }\end{array}$ & www.enterprisedb.com \\
\hline 19 & FiveRuns & 2005 & $\begin{array}{l}\text { Austin, TX 78730, } \\
\text { USA }\end{array}$ & www.fiveruns.com \\
\hline 20 & Fonality & 2003 & $\begin{array}{l}\text { Los Angeles, CA } \\
90230, \text { USA }\end{array}$ & www.fonality.com \\
\hline 21 & Funambol & 2002 & $\begin{array}{l}\text { Redwood City, CA } \\
94063 \text {, USA }\end{array}$ & www.funambol.com \\
\hline 22 & Greenplum & 2003 & $\begin{array}{l}\text { San Mateo, CA } \\
\text { 94403, USA }\end{array}$ & www.greenplum.com \\
\hline 23 & $\begin{array}{l}\text { GroundWork Open } \\
\text { Source }\end{array}$ & 2004 & $\begin{array}{l}\text { San Francisco, CA } \\
\text { 94107, USA }\end{array}$ & www.groundworkopensource.com \\
\hline 24 & Hyperic & 2004 & $\begin{array}{l}\text { San Francisco, CA } \\
94105, \text { USA }\end{array}$ & www.hyperic.com \\
\hline
\end{tabular}




\begin{tabular}{|c|c|c|c|c|}
\hline 25 & JasperSoft & 2004 & $\begin{array}{l}\text { San Francisco, CA } \\
\text { 94107, USA }\end{array}$ & www.jaspersoft.com \\
\hline 26 & Koders & 2004 & $\begin{array}{l}\text { Santa Monica, CA } \\
\text { 90403, USA }\end{array}$ & www.koders.com \\
\hline 27 & Krugle* & 2005 & $\begin{array}{l}\text { Menlo Park, CA } \\
\text { 94025, USA }\end{array}$ & www.krugle.com \\
\hline 28 & Laszlo Systems & 2000 & $\begin{array}{l}\text { San Mateo, CA } \\
\text { 94403, USA }\end{array}$ & www.laszlosystems.com \\
\hline 29 & LucidEra & 2005 & $\begin{array}{l}\text { San Mateo, CA } \\
\text { 94404, USA }\end{array}$ & www.lucidera.com \\
\hline 30 & MedSphere & 2002 & $\begin{array}{l}\text { Aliso Viejo, CA } \\
\text { 92656, USA }\end{array}$ & www.medsphere.com \\
\hline 31 & MuleSource & 2006 & $\begin{array}{l}\text { San Francisco, CA } \\
\text { 94105, USA }\end{array}$ & www.mulesource.com \\
\hline 32 & OpenClovis & 2002 & $\begin{array}{l}\text { Petaluma, CA } 94954, \\
\text { USA }\end{array}$ & www.openclovis.com \\
\hline 33 & Open-Xchange & 2005 & $\begin{array}{l}\text { Tarrytown, NY } \\
\text { 10591, USA }\end{array}$ & www.open-xchange.com \\
\hline 34 & Optaros & 2004 & $\begin{array}{l}\text { Boston, MA 02108, } \\
\text { USA }\end{array}$ & www.optaros.com \\
\hline 35 & Palamida* & 2003 & $\begin{array}{l}\text { San Francisco, CA } \\
\text { 94105, USA }\end{array}$ & www.palamida.com \\
\hline 36 & Pentaho & 2004 & $\begin{array}{l}\text { Orlando, FL 32822, } \\
\text { USA }\end{array}$ & www.pentaho.com \\
\hline 37 & PostPath & 2003 & $\begin{array}{l}\text { Mountain View, CA } \\
94041-1106, \text { USA }\end{array}$ & www.postpath.com \\
\hline 38 & Qlusters & 2001 & $\begin{array}{l}\text { Palo Alto, CA 94304, } \\
\text { USA }\end{array}$ & www.qlusters.com \\
\hline 39 & rPath & 2005 & $\begin{array}{l}\text { Raleigh, NC 27607, } \\
\text { USA }\end{array}$ & www.rpath.com \\
\hline 40 & Scalix* & 2002 & $\begin{array}{l}\text { New York, NY } \\
10016, \text { USA } \\
\end{array}$ & www.scalix.com \\
\hline 41 & SiCortex & 2003 & $\begin{array}{l}\text { Maynard, MA 01754, } \\
\text { USA }\end{array}$ & www.sicortex.com \\
\hline 42 & SIPphone & 2003 & $\begin{array}{l}\text { San Diego, CA } \\
\text { 92121, USA } \\
\end{array}$ & www.sipphone.com \\
\hline 43 & Socialtext & 2003 & $\begin{array}{l}\text { Palo Alto, CA 94301, } \\
\text { USA }\end{array}$ & www.socialtext.com \\
\hline 44 & SourceLabs & 2004 & $\begin{array}{l}\text { Seattle, WA } 98104, \\
\text { USA }\end{array}$ & www.sourcelabs.com \\
\hline 45 & SpikeSource & 2003 & $\begin{array}{l}\text { Redwood City, CA } \\
94063, \text { USA }\end{array}$ & www.spikesource.com \\
\hline 46 & Splunk & 2004 & $\begin{array}{l}\text { San Francisco, CA } \\
\text { 94107, USA }\end{array}$ & www.splunk.com \\
\hline 47 & SugarCRM & 2004 & $\begin{array}{l}\text { Cupertino, CA 95014, } \\
\text { USA }\end{array}$ & www.sugarcrm.com \\
\hline 48 & Talend & 2006 & $\begin{array}{l}\text { Los Altos, CA 94022, } \\
\text { USA }\end{array}$ & www.talend.com \\
\hline 49 & Terracotta & 2003 & $\begin{array}{l}\text { San Francisco, CA } \\
\text { 94103, USA }\end{array}$ & www.terracottatech.com \\
\hline 50 & Terascala & 2005 & $\begin{array}{l}\text { Avon, MA 02322, } \\
\text { USA }\end{array}$ & www.terascala.com \\
\hline
\end{tabular}




\begin{tabular}{|l|l|l|l|l|}
\hline 51 & $\begin{array}{l}\text { Transera } \\
\text { Communications }\end{array}$ & 2004 & $\begin{array}{l}\text { Sunnyvale, CA } \\
\text { 94087, USA }\end{array}$ & www.transerainc.com \\
\hline 52 & Univa UD* & 2004 & Lisle, IL 60532, USA & www.univaud.com \\
\hline 53 & Untangle & 2003 & $\begin{array}{l}\text { San Mateo, CA } \\
\text { 94403, USA }\end{array}$ & www.untangle.com \\
\hline 54 & VirtualLogix & 2002 & $\begin{array}{l}\text { Sunnyvale, CA } \\
\text { 94089, USA }\end{array}$ & www.virtuallogix.com \\
\hline 55 & VirtualIron & 2003 & $\begin{array}{l}\text { Lowell, MA 01851, } \\
\text { USA }\end{array}$ & www.virtualiron.com \\
\hline 56 & Vyatta & 2005 & $\begin{array}{l}\text { San Mateo, CA } \\
\text { 94002, USA }\end{array}$ & www.vyatta.com \\
\hline 57 & Wikia & 2004 & $\begin{array}{l}\text { San Mateo, CA } \\
94401, \text { USA }\end{array}$ & www.wikia.com \\
\hline 58 & WS02 & 2005 & $\begin{array}{l}\text { Mountain View, CA } \\
94041, \text { USA }\end{array}$ & wso2.com \\
\hline 59 & Xandros* & 2001 & $\begin{array}{l}\text { New York, NY } \\
10016, \text { USA }\end{array}$ & www.xandros.com \\
\hline 60 & Zenoss* & 2005 & $\begin{array}{l}\text { Annapolis, MD } \\
\text { 21401, USA }\end{array}$ & www.zenoss.com \\
\hline 61 & Zmanda & 2005 & $\begin{array}{l}\text { Sunnyvale, CA } \\
\text { 94086, USA }\end{array}$ & www.zmanda.com \\
\hline
\end{tabular}




\section{Appendix B: List of companies' market offers and community development}

\section{activities}

\begin{tabular}{|c|c|c|c|c|c|}
\hline & Company & Year & Place & Market offers & $\begin{array}{l}\text { Community } \\
\text { development }\end{array}$ \\
\hline 1 & $\begin{array}{l}\text { ActiveGrid } \\
\text { (WaveMaker) }\end{array}$ & 2003 & $\begin{array}{l}\text { CA, } \\
\text { USA }\end{array}$ & $\begin{array}{l}\text { Products/Applications: OS } \\
\text { license (AGPL v3), and } \\
\text { commercial license } \\
\text { - Support: services and support } \\
\text { that enterprises require }\end{array}$ & $\begin{array}{l}\text { - Community, } \\
\text { forum }\end{array}$ \\
\hline 2 & $\begin{array}{l}\text { Adaptive } \\
\text { Planning }\end{array}$ & 2003 & $\begin{array}{l}\text { CA, } \\
\text { USA }\end{array}$ & $\begin{array}{l}\text { Products: express edition } \\
\text { (OS/GPL), corporate edition, } \\
\text { enterprise, Software as a service } \\
\text { (SaaS) solution } \\
\text { - Services: implementation, } \\
\text { training, and support } \\
\text { - Product support: community } \\
\text { support, standard support, and } \\
\text { premium support }\end{array}$ & - Community \\
\hline 3 & Alfresco & 2005 & $\begin{array}{l}\mathrm{CA} \\
\mathrm{USA}\end{array}$ & $\begin{array}{l}\text { Products: Alfresco enterprise, } \\
\text { and Alfresco community (GPL) } \\
\text { Services; a range of support } \\
\text { options; a full range of training } \\
\text { services; a full range of } \\
\text { consulting and professional } \\
\text { services offerings }\end{array}$ & $\begin{array}{l}\text { - Community, } \\
\text { forum } \\
\text { - Wiki, blog }\end{array}$ \\
\hline 4 & Appscio & 2006 & $\begin{array}{l}\mathrm{CA} \\
\mathrm{USA}\end{array}$ & $\begin{array}{l}\text { Products: a services platform to } \\
\text { organize raw video streams, } \\
\text { either live or recorded, into } \\
\text { structured, coherent and } \\
\text { actionable information }\end{array}$ & \\
\hline 5 & Astaro & 2000 & $\begin{array}{l}\text { MA, } \\
\text { USA }\end{array}$ & $\begin{array}{l}\text { Products: Astaro Security } \\
\text { Gateway, Astaro Command } \\
\text { Center, Astaro Report Manager, } \\
\text { Astaro VPN Clients } \\
\end{array}$ & \\
\hline 6 & Automattic & 2005 & $\begin{array}{l}\text { CA, } \\
\text { USA }\end{array}$ & $\begin{array}{l}\text { Support; services for WordPress } \\
\text { and WordPress MU (Multi- } \\
\text { User) through the Automattic } \\
\text { Support Network (basic, } \\
\text { premium) } \\
\text { - Advanced services: } \\
\text { WordPress.com premium } \\
\text { features, WordPress.com VIP } \\
\text { hosting }\end{array}$ & $\begin{array}{l}\text { Codex } \\
\text { community, } \\
\text { forum } \\
\text { - Wiki, blog }\end{array}$ \\
\hline 7 & $\begin{array}{l}\text { Barracuda } \\
\text { Networks }\end{array}$ & 2002 & $\begin{array}{l}\text { CA, } \\
\text { USA }\end{array}$ & $\begin{array}{l}\text { Products: Barracuda Spam } \\
\text { Firewall, Barracuda Web Filter, } \\
\text { Barracuda IM Firewall, } \\
\text { Barracuda Load Balancer, } \\
\text { Barracuda Message Archiver, } \\
\text { Web Application Controllers }\end{array}$ & $\begin{array}{l}\text { - Community, } \\
\text { forum }\end{array}$ \\
\hline
\end{tabular}




\begin{tabular}{|c|c|c|c|c|c|}
\hline 8 & BitTorrent & 2004 & $\begin{array}{l}\mathrm{CA}, \\
\text { USA }\end{array}$ & $\begin{array}{l}\text { Products: BitTorrent SDK for } \\
\text { devices } \\
\text { - Services: delivering high-quality } \\
\text { files and an online destination } \\
\text { for downloadable and ad- } \\
\text { supported streaming } \\
\text { entertainment content @ Torrent } \\
\text { Entertainment Network; content } \\
\text { delivery service through } \\
\text { BitTorrent DNA } \\
\text { Test service through BitTorrent } \\
\text { Certified } \\
\end{array}$ & - Client forum \\
\hline 9 & $\begin{array}{l}\text { Black Duck } \\
\text { Software }\end{array}$ & 2002 & $\begin{array}{l}\text { MA, } \\
\text { USA }\end{array}$ & $\begin{array}{l}\text { Products: Code Center, } \\
\text { protexIP, protexIP/sdk, } \\
\text { exportIP, transactIP } \\
\text { - Professional services } \\
\text { - } \text { Training } \\
\text { Customer support }\end{array}$ & \\
\hline 10 & Centeris & 2004 & $\begin{array}{l}\text { WA, } \\
\text { USA }\end{array}$ & $\begin{array}{l}\text { Products (Solutions): Likewise } \\
\text { Open (OS/ GPL), Likewise } \\
\text { Enterprise } \\
\text { - Support offerings: pre-sales } \\
\text { support, silver support, and gold } \\
\text { support }\end{array}$ & $\begin{array}{l}\text { Community, bug } \\
\text { tracking via } \\
\text { Bugzilla }\end{array}$ \\
\hline 11 & CIGNEX & 2000 & $\begin{array}{l}\text { CA, } \\
\text { USA }\end{array}$ & $\begin{array}{l}\text { Solutions: Web content } \\
\text { management, Intranets and } \\
\text { collaboration, document } \\
\text { management, records } \\
\text { management, portals, and } \\
\text { content intelligence } \\
\text { - Services: consulting, design, } \\
\text { migration, development, } \\
\text { maintenance, integration, } \\
\text { support, training }\end{array}$ & - Community, blog \\
\hline 12 & Cleversafe & 2004 & $\begin{array}{l}\mathrm{IL} \\
\text { USA }\end{array}$ & $\begin{array}{l}\text { Products: three components that } \\
\text { form a Dispersed Storage } \\
\text { Network (dsNet) } \\
\text { - Solutions } \\
\text { - Support: customer support, } \\
\text { training \& education, and } \\
\text { documentation } \\
\end{array}$ & $\begin{array}{l}\text { Community, } \\
\text { forum, blog }\end{array}$ \\
\hline 13 & $\begin{array}{l}\text { Coupa } \\
\text { Software }\end{array}$ & 2006 & $\begin{array}{l}\text { CA, } \\
\text { USA }\end{array}$ & $\begin{array}{l}\text { - Products: unlimited, premier, } \\
\text { standard, basic, express } \\
\text { (OS/GPL) } \\
\text { - Support: support center }\end{array}$ & $\begin{array}{l}\text { - Community, } \\
\text { forum }\end{array}$ \\
\hline 14 & $\begin{array}{l}\text { Collaborative } \\
\text { Software } \\
\text { Initiative }\end{array}$ & 2007 & $\begin{array}{l}\text { OR, } \\
\text { USA }\end{array}$ & $\begin{array}{l}\text { Services: collaboration \& } \\
\text { community building, project } \\
\text { management, technical support } \\
\& \text { maintenance, OSS foundation } \\
\text { development \& management }\end{array}$ & \\
\hline
\end{tabular}




\begin{tabular}{|c|c|c|c|c|c|}
\hline 15 & Continuent & 2004 & $\begin{array}{l}\text { CA, } \\
\text { USA }\end{array}$ & $\begin{array}{l}\text { Products: Continuent }{ }^{\mathrm{TM}} \\
\text { uni/cluster - middleware } \\
\text { - } \quad \text { Support: self-service portal, } \\
\text { support levels (basic support, } \\
\text { extended support, enterprise } \\
\text { support, custom support), } \\
\text { consulting services }\end{array}$ & $\begin{array}{l}\text { Community, } \\
\text { issue tracking via } \\
\text { JIRA }\end{array}$ \\
\hline 16 & db4objects & 2004 & $\begin{array}{l}\text { CA, } \\
\text { USA }\end{array}$ & $\begin{array}{l}\text { Solutions: mobile carriers, } \\
\text { navigation and telematic } \\
\text { systems, network and } \\
\text { transportation control systems, } \\
\text { devices and equipment, mobile } \\
\text { enterprise } \\
\text { - Products: db4o database runtime } \\
\text { engine, db4o Replication } \\
\text { System (dRS), ObjectManager, } \\
\text { XtremeConnect (commercial } \\
\text { packages: dDN Enterprise, } \\
\text { Commercial db4o Runtime } \\
\text { Licenses) } \\
\text { - Support and software } \\
\text { maintenance: db4o Developer } \\
\text { Network (dDN) }\end{array}$ & $\begin{array}{l}\text { - Community, } \\
\text { forum }\end{array}$ \\
\hline 17 & Devicescape & 2001 & $\begin{array}{l}\text { CA, } \\
\text { USA }\end{array}$ & $\begin{array}{l}\text { Products: Devicescape Security } \\
\text { for home Wi-Fi, Devicescape } \\
\text { Security for enterprise Wi-Fi, } \\
\text { and Devicescape Connect for } \\
\text { commercial and free/open } \\
\text { (GPL) hotspots } \\
\text { - Services: professional services } \\
\text { to help device manufacturers get } \\
\text { their products to market, and } \\
\text { assist in porting and integrating } \\
\text { our Devicescape technology } \\
\text { into the device design } \\
\text { - Support: assistance that includes } \\
\text { telephone and email } \\
\text { consultation, web forums, and } \\
\text { training, updates with additional } \\
\text { features, patches, and technical } \\
\text { notes are available to customers } \\
\text { with active maintenance } \\
\text { agreements, and technical } \\
\text { support web portal for licensed } \\
\text { customers }\end{array}$ & $\begin{array}{l}\text { Community, } \\
\text { forum, blog }\end{array}$ \\
\hline
\end{tabular}




\begin{tabular}{|c|c|c|c|c|c|}
\hline 18 & EnterpriseDB & 2004 & $\begin{array}{l}\mathrm{NJ}, \\
\text { USA }\end{array}$ & $\begin{array}{l}\text { - Products: Postgres Plus } \\
\text { (basic/premium), Postgres Plus } \\
\text { Advanced Server (Postgres Plus } \\
\text { Advanced Server (developer- } \\
\text { free/subscription) } \\
\text { - Support: learning center } \\
\text { - Services: support services, } \\
\text { professional services (daily } \\
\text { DBA, fast track deployment, } \\
\text { Postgres health check, Postgres } \\
\text { Plus performance tuning } \\
\text { replication set-up, high- } \\
\text { availability set-up, custom } \\
\text { services) } \\
\text { Training: training courses to } \\
\text { developers and DBAs on a wide } \\
\text { variety of topics: database } \\
\text { administration, database } \\
\text { troubleshooting, database } \\
\text { replication, database design, and } \\
\text { server-side programming }\end{array}$ & $\begin{array}{l}\text { Community, } \\
\text { forum, blog }\end{array}$ \\
\hline 19 & FiveRuns & 2005 & $\begin{array}{l}\text { TX, } \\
\text { USA }\end{array}$ & $\begin{array}{l}\text { Products: RM-Manage (hosted } \\
\text { product-a web-based), and RM- } \\
\text { Install (OS/Apache License 2.0) } \\
\text { - Support }\end{array}$ & \\
\hline 20 & Fonality & 2003 & $\begin{array}{l}\text { CA, } \\
\text { USA }\end{array}$ & $\begin{array}{l}\text { Products: PBXtra (standard, } \\
\text { professional, and call centers), } \\
\text { HUD (personal-free, team, and } \\
\text { agent) } \\
\text { - Solutions: call centers, business } \\
\text { communication solutions for } \\
\text { SMBs } \\
\text { Support: free installation } \\
\text { support, } 24 \times 7 \text { emergency } \\
\text { support, free software updates, } \\
\text { paid support, and annual } \\
\text { software maintenance and } \\
\text { support pricing }\end{array}$ & \\
\hline
\end{tabular}




\begin{tabular}{|c|c|c|c|c|c|}
\hline 21 & Funambol & 2002 & $\begin{array}{l}\text { CA, } \\
\text { USA }\end{array}$ & $\begin{array}{l}\text { Products: community edition } \\
\text { (OS/ GPL), and the commercial } \\
\text { carrier edition } \\
\text { Industry solutions: push email } \\
\text { for the mass market, mobile } \\
\text { backup \& PIM sync, device } \\
\text { management and an open source } \\
\text { platform to mobilize } \\
\text { applications and data for several } \\
\text { types of organizations, including } \\
\text { service providers, OEMs, ISVs, } \\
\text { and ODMs and enterprises } \\
\text { Services: consulting services, } \\
\text { training (KickStart package), } \\
\text { support options (annual } \\
\text { software maintenance and } \\
\text { technical support \& community } \\
\text { support) }\end{array}$ & $\begin{array}{l}\text { - Community, } \\
\text { forum } \\
\text { - Wiki, blog }\end{array}$ \\
\hline 22 & Greenplum & 2003 & $\begin{array}{l}\text { CA, } \\
\text { USA }\end{array}$ & $\begin{array}{l}\text { Products: Greenplum database } \\
\text { (commercial), Bizgres } \\
\text { (OS/BSD) } \\
\text { - Support: Free support for } 30 \\
\text { days, standard and enterprise } \\
\text { support } \\
\text { - Services: accessible via } \\
\text { Greenplum Network (GPN) -- } \\
\text { Resource Center } \\
\text { - Education } \\
\text { - Consulting } \\
\text { - Industry solutions: financial } \\
\text { services, communications \& } \\
\text { media, retail, manufacturing, } \\
\text { government, transportation, } \\
\text { Web analytics }\end{array}$ & $\begin{array}{l}\text { Community, } \\
\text { forum }\end{array}$ \\
\hline 23 & $\begin{array}{l}\text { GroundWork } \\
\text { Open Source }\end{array}$ & 2004 & $\begin{array}{l}\text { CA, } \\
\text { USA }\end{array}$ & $\begin{array}{l}\text { Solutions: GroundWork } \\
\text { Monitor (proprietary products } \\
\text { like HP OpenView Operations } \\
\text { or BMC Patrol } \\
\text { - Products: enterprise, } \\
\text { professional, and community } \\
\text { (OS/GPL v2) } \\
\text { - Services \& support: standard, } \\
\text { premier ( } 24 \times 7 \text { ), web-based } \\
\text { GroundWork connect, } \\
\text { professional services } \\
\text { Training: full schedule, getting } \\
\text { started with GroundWork, } \\
\text { hosting monthly live webcast } \\
\text { sessions }\end{array}$ & $\begin{array}{l}\text { - Community, } \\
\text { forum }\end{array}$ \\
\hline
\end{tabular}




\begin{tabular}{|c|c|c|c|c|c|}
\hline 24 & Hyperic & 2004 & $\begin{array}{l}\text { CA, } \\
\text { USA }\end{array}$ & $\begin{array}{l}\text { Products: Hyperic HQ } \\
\text { (OS/GPL-silver), Hyperic HQ } \\
\text { Enterprise (gold/diamond), } \\
\text { SIGAR (System Information } \\
\text { Gatherer and } \\
\text { Reporter/OS/GPL), Plugin } \\
\text { Reference Library } \\
\text { (HyperFORGE) } \\
\text { - Support: community support, } \\
\text { subscription support (silver/gold } \\
\text { /diamond), enterprise updates, } \\
\text { onsite support \& training } \\
\text { Training: Hyperic 101, Hyperic } \\
\text { custom training }\end{array}$ & $\begin{array}{l}\text { Community, } \\
\text { forum }\end{array}$ \\
\hline 25 & JasperSoft & 2004 & $\begin{array}{l}\text { CA, } \\
\text { USA }\end{array}$ & $\begin{array}{l}\text { Products: JasperServer } \\
\text { professional, JasperSoft BI } \\
\text { suite, JasperServer community } \\
\text { edition and JasperReports } \\
\text { community edition (OS/GPL) } \\
\text { - Technical support: per-incident } \\
\text { and annual subscriptions } \\
\text { - Professional services: } \\
\text { consultance, JasperSoft BI suite } \\
\text { jumpstart, workshop } \\
\text { - Training: convenient online or } \\
\text { on-site education, JasperSoft BI } \\
\text { suite training, JasperServer } \\
\text { training, course }\end{array}$ & $\begin{array}{l}\text { Community, } \\
\text { forum, bug } \\
\text { tracker }\end{array}$ \\
\hline 26 & Koders & 2004 & $\begin{array}{l}\text { CA, } \\
\text { USA }\end{array}$ & $\begin{array}{l}\text { Products: Koders.com } \\
\text { (free/Open Source Code search), } \\
\text { Koders Pro, Koders enterprise } \\
\text { edition, and plug-in for the IDE } \\
\text { Eclipse and an add-in for } \\
\text { Microsoft Visual Studio } \\
\text { - Support: Koders forums, FAQs, } \\
\text { online help (major and minor } \\
\text { updates, documentation), } \\
\text { feedback }\end{array}$ & $\begin{array}{l}\text { Community, } \\
\text { forum, blog }\end{array}$ \\
\hline 27 & Krugle* & 2005 & $\begin{array}{l}\text { CA, } \\
\text { USA }\end{array}$ & $\begin{array}{l}\text { Products: Krugle enterprise, } \\
\text { Krugle DevNetwork, Krugle } \\
\text { public (OS/AGPL v3) } \\
\text { - Support: online support, } \\
\text { telephone support, support } \\
\text { packages } \\
\text { (evaluations/basic/premium), } \\
\text { support priority (P1/P2/P3/P4) }\end{array}$ & $\begin{array}{l}\text { Community, } \\
\text { forum, blog }\end{array}$ \\
\hline
\end{tabular}




\begin{tabular}{|c|c|c|c|c|c|}
\hline 28 & Laszlo Systems & 2000 & $\begin{array}{l}\text { CA, } \\
\text { USA }\end{array}$ & $\begin{array}{l}\text { Products/applications: Laszlo } \\
\text { Webtop (service } \\
\text { providers/enterprises/developers } \\
\text { ), OpenLaszlo (GPL), Laszlo } \\
\text { Mail (commercial applications) } \\
\text { - Services: professional services } \\
\text { (laszlo studios/consulting } \\
\text { packages), OpenLaszlo training } \\
\text { (online workshop/OpenLaszlo } \\
\text { fundamentals/building } \\
\text { OpenLaszlo applications/onsite } \\
\text { training), support programs } \\
\text { (Laszlo developer network: } \\
\text { standard developer, premium } \\
\text { developer, enterprise } \\
\text { developer), developer incident } \\
\text { support }\end{array}$ & $\begin{array}{l}\text { - Community, } \\
\text { forum }\end{array}$ \\
\hline 29 & LucidEra & 2005 & $\begin{array}{l}\text { CA, } \\
\text { USA }\end{array}$ & $\begin{array}{l}\text { Products/applications: LucidEra } \\
\text { enterprise, LucidEra for } \\
\text { Salesforce.com (integration into } \\
\text { Salesforce.com), LucidEra for } \\
\text { Oracle order management, on- } \\
\text { demand analytics platform } \\
\text { - Solutions: sales (CRM } \\
\text { systems/sales questions), sales } \\
\text { operations (sales operations } \\
\text { questions), finance (financial } \\
\text { systems, finance questions), IT } \\
\text { - Services: Service Level } \\
\text { Agreement (application } \\
\text { availability and uptime } \\
\text { guarantee/maintenance/upgrade } \\
\text { schedule), phone support, } \\
\text { security, privacy }\end{array}$ & \\
\hline 30 & MedSphere & 2002 & $\begin{array}{l}\text { CA, } \\
\text { USA }\end{array}$ & $\begin{array}{l}\text { Products: OpenVista }{ }^{\mathrm{TM}} \text { for the } \\
\text { enterprise, OpenVista } \\
\text { clinic, OpenVista Clinical } \\
\text { Information System (CIS) } \\
\text { (MSPL), OpenVista Server } \\
\text { (GPL) } \\
\text { - Services: implementation, } \\
\text { training, support, development }\end{array}$ & \\
\hline 31 & MuleSource & 2006 & $\begin{array}{l}\text { CA, } \\
\text { USA }\end{array}$ & $\begin{array}{l}\text { Products: Mule Enterprise } \\
\text { Service Bus (ESB, } \\
\text { silver/gold/platinum), Mule } \\
\text { community edition (OS/GPL } \\
\text { v2), Mule Galaxy SOA } \\
\text { governance platform, Mule } \\
\text { Saturn Data monitoring } \\
\text { platform, MULE HQ, Mule IDE } \\
\text { - Services: subscriptions, } \\
\text { education, consulting, support } \\
\text { tiers, Quickstart program }\end{array}$ & $\begin{array}{l}\text { - Community, } \\
\text { forum }\end{array}$ \\
\hline
\end{tabular}




\begin{tabular}{|c|c|c|c|c|c|}
\hline 32 & OpenClovis & 2002 & $\begin{array}{l}\text { CA, } \\
\text { USA }\end{array}$ & $\begin{array}{l}\text { Products: OpenClovis } \\
\text { Application Service Platform, } \\
\text { OpenClovis IDE } \\
\text { - Support \& services: tech support } \\
\text { (standard/professional/enterprise } \\
\text { ), training, consulting services } \\
\end{array}$ & - Community \\
\hline 33 & Open-Xchange & 2005 & $\begin{array}{l}\text { NY, } \\
\text { USA }\end{array}$ & $\begin{array}{l}\text { Products: Open-Xchange } \\
\text { community edition (OS/GPL } \\
\text { v2), Open-Xchange express } \\
\text { edition, Open-Xchange server, } \\
\text { Open-Xchange hosting edition, } \\
\text { Open-Xchange mobility } \\
\text { solutions } \\
\text { - Services: support offerings } \\
\text { (maintenance } \\
\text { subscription/installation } \\
\text { support/advanced support), } \\
\text { additional support (maintenance } \\
\text { portal) } \\
\text { Training: administration } \\
\text { workshop, administration } \\
\text { module, user workshop }\end{array}$ & $\begin{array}{ll}\text { - } & \text { Community, } \\
\text { forum } \\
\text { - Wiki }\end{array}$ \\
\hline 34 & Optaros & 2004 & $\begin{array}{l}\text { MA, } \\
\text { USA }\end{array}$ & $\begin{array}{l}\text { Solutions: solutions by industry } \\
\text { - Approaches: designing } \\
\text { enterprise applications, rapid } \\
\text { design of customer-facing } \\
\text { applications, benefits of user } \\
\text { experience design } \\
\text { - Assembly methodology: } \\
\text { blueprint assembly, solution } \\
\text { assembly, support (a variety of } \\
\text { support plans), integrated } \\
\text { assembly environment (wiki- } \\
\text { based content repository }\end{array}$ & \\
\hline 35 & Palamida* & 2003 & $\begin{array}{l}\text { CA, } \\
\text { USA }\end{array}$ & $\begin{array}{l}\text { Products: IP amplifier, IP } \\
\text { authorizer } \\
\text { - Services: vulnerability reporting } \\
\text { audits (vulnerability reporting), } \\
\text { M\&A audits (M\&A solution), } \\
\text { enterprise audits, and QuickStart } \\
\text { services } \\
\text { - Support; ramp and go support } \\
\text { package, plus and premier } \\
\text { corporate support packages } \\
\text { (annual subscription) }\end{array}$ & \\
\hline 36 & Pentaho & 2004 & $\begin{array}{l}\text { FL, } \\
\text { USA }\end{array}$ & $\begin{array}{l}\text { Products: Pentaho Open BI } \\
\text { Suite (OS/MPL 1.1) } \\
\text { Services: professional support } \\
\text { (gold/platinum), training, } \\
\text { consulting (business } \\
\text { consulting/technical consulting), } \\
\text { ISV/OEM support, services, } \\
\text { WebEx event center }\end{array}$ & $\begin{array}{ll}\text { - } & \text { Community, } \\
\text { forum } \\
\text { - Wiki }\end{array}$ \\
\hline
\end{tabular}




\begin{tabular}{|c|c|c|c|c|c|}
\hline 37 & PostPath & 2003 & $\begin{array}{l}\text { CA, } \\
\text { USA }\end{array}$ & $\begin{array}{l}\text { Products: PostPath Server (a } \\
\text { commercial product), PostPath } \\
\text { WebMail, PostPath Server } \\
\text { VMware Edition (free) } \\
\text { - Solutions: exchange } \\
\text { replacement solutions, archiving } \\
\text { and anti-virus, storage, lean } \\
\text { infrastructure } \\
\text { - Support: support options (free } \\
\text { support/standard } \\
\text { support/enhanced support) }\end{array}$ & \\
\hline 38 & Qlusters & 2001 & $\begin{array}{l}\text { CA, } \\
\text { USA }\end{array}$ & $\begin{array}{l}\text { Products: openQRM OS license } \\
\text { (modified MPL), and } \\
\text { commercial license } \\
\text { - Support: hotline, on-line } \\
\text { customer support system }\end{array}$ & \\
\hline 39 & rPath & 2005 & $\begin{array}{l}\mathrm{NC} \\
\mathrm{USA}\end{array}$ & $\begin{array}{l}\text { - Products: rBuilder (GPL), rPath } \\
\text { appliance platform (GPL) } \\
\text { - Services: consulting services } \\
\text { - Support: standard and premium, } \\
\text { online issue tracking system, } \\
\text { documentation wiki, hardware } \\
\text { support } \\
\text { - Training: application packaging } \\
\text { and appliance building } \\
\text { methodology }\end{array}$ & 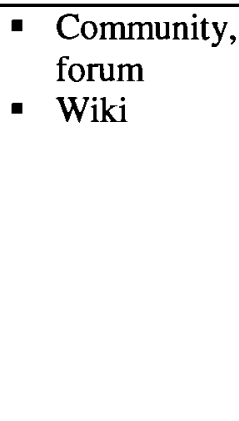 \\
\hline 40 & Scalix* & 2002 & $\begin{array}{l}\text { NY, } \\
\text { USA }\end{array}$ & $\begin{array}{l}\text { Products: enterprise edition, } \\
\text { small business edition, } \\
\text { community edition (OS/SPL), } \\
\text { hosted edition, univention } \\
\text { edition } \\
\text { Support: technical training, on- } \\
\text { site employment services, and } \\
24 \times 7 \text { Premium Support plan } \\
\text { (Post-development) }\end{array}$ & $\begin{array}{l}\text { - Community, } \\
\text { forum } \\
\text { - Wiki }\end{array}$ \\
\hline 41 & SiCortex & 2003 & $\begin{array}{l}\text { MA, } \\
\text { USA }\end{array}$ & $\begin{array}{l}\text { Products: SC5832 (The } \\
\text { SiCortex SC5832 is the first } \\
\text { computer architecture to } \\
\text { recognize that high sustained } \\
\text { performance and low power are } \\
\text { synergistic, not antagonistic.), } \\
\text { SC1458, SC648, SC072 } \\
\text { - Support: login }\end{array}$ & \\
\hline 42 & SIPphone & 2003 & $\begin{array}{l}\text { CA, } \\
\text { USA }\end{array}$ & $\begin{array}{l}\text { Products: VoIP hardware } \\
\text { - Support: knowledgebase, forum }\end{array}$ & \\
\hline 43 & Socialtext & 2003 & $\begin{array}{l}\text { CA, } \\
\text { USA }\end{array}$ & $\begin{array}{l}\text { Products: Socialtext wiki } \\
\text { enterprise, professional, } \\
\text { personal, OS (CPALArtistic } \\
\text { License } 2.0 \text { ) } \\
\text { - } \\
\text { Support: customer login } \\
\end{array}$ & - Wiki, blog \\
\hline
\end{tabular}




\begin{tabular}{|c|c|c|c|c|c|}
\hline 44 & SourceLabs & 2004 & $\begin{array}{l}\text { WA, } \\
\text { USA }\end{array}$ & $\begin{array}{l}\text { Products: SourceLabs self- } \\
\text { support suite, Sash } 2.0 \\
\text { developer (commercial), Sash } \\
2.0 \text { (OS/GPL) } \\
\text { - Support: SourceLabs self } \\
\text { support suite for Linux and } \\
\text { Open Source Java (intro } \\
\text { offer/fully supported: annual } \\
\text { subscription), SourceLabs } \\
\text { continuous support system } \\
\text { (CS2), Open Source } \\
\text { Management System (OSMS), } \\
\text { Sash 2 - Java development stack } \\
\text { - Solutions: SourceLabs } \\
\text { continuous support solution for } \\
\text { java middleware }\end{array}$ & - Community \\
\hline 45 & SpikeSource & 2003 & $\begin{array}{l}\text { CA, } \\
\text { USA }\end{array}$ & $\begin{array}{l}\text { Applications/solutions: Intel@ } \\
\text { Certified solutions program, } \\
\text { SpikeSource solutions factory, } \\
\text { Open Source Apps for Windows } \\
\text { Server } 2008 \text { (Free), SuiteTwo - } \\
\text { Powered by Intel (From } \\
\$ 2495 / \text { hosted or from } \\
\$ 990 / \text { software only), Drupal } \\
\text { SpikeIgnited, SpikeSource } \\
\text { solutions for email, calendaring } \\
\text { and collaboration, Centric CRM } \\
\text { SpikeIgnited solution, } \\
\text { JasperSoft SpikeIgnited BI suite } \\
\text { - Support is incorporated in the } \\
\text { solutions } \\
\end{array}$ & $\begin{array}{l}\text { - Community, } \\
\text { forum }\end{array}$ \\
\hline 46 & Splunk & 2004 & $\begin{array}{l}\text { CA, } \\
\text { USA }\end{array}$ & $\begin{array}{l}\text { - Products: Splunk free/enterprise } \\
\text { - Applications: availability, } \\
\text { security, compliance, BI } \\
\text { - Support: community support, } \\
\text { enterprise support, global } \\
\text { support (priority levels: P1-P4) } \\
\text { - Education programs: self- } \\
\text { guided, instructor-led, } \\
\text { certification tracks } \\
\text { - Professional services: } \\
\text { installation and configuration } \\
\text { services (e.g., } \$ 2,000 \text { per day), } \\
\text { customization services, design } \\
\text { services, integration services }\end{array}$ & $\begin{array}{l}\text { - Community, } \\
\text { forum }\end{array}$ \\
\hline
\end{tabular}




\begin{tabular}{|c|c|c|c|c|c|}
\hline 47 & SugarCRM & 2004 & $\begin{array}{l}\text { CA, } \\
\text { USA }\end{array}$ & $\begin{array}{l}\text { Products: Sugar community } \\
\text { (OS/GPL v3), Sugar enterprise } \\
\text { (on-site), Sugar professional } \\
\text { (on-site), Sugar on-demand } \\
\text { (host/enterprise/professional) } \\
\text { - Customer support: case } \\
\text { management, inbound email, } \\
\text { knowledgebase, bug tracking, } \\
\text { self-service portal } \\
\text { - Services: support services } \\
\text { (standard support/extended } \\
\text { support/premium support), } \\
\text { implementation services, } \\
\text { professional services, sugar } \\
\text { network } \\
\text { Training: online library, } \\
\text { learning, sessions, classroom, } \\
\text { sugar university offerings }\end{array}$ & $\begin{array}{l}\text { Community, } \\
\text { forum } \\
\text { - Wiki }\end{array}$ \\
\hline 48 & Talend & 2006 & $\begin{array}{l}\text { CA, } \\
\text { USA }\end{array}$ & $\begin{array}{l}\text { Products: Talend open studio } \\
\text { (OS/GPL v2), Talend } \\
\text { integration suite, Talend on } \\
\text { demand (SaaS: silver } \\
\text { support/gold support/silver } \\
\text { support) } \\
\text { - Solutions: operational data } \\
\text { integration, data migration, data } \\
\text { synchronization, ETL for BI and } \\
\text { data warehousing } \\
\text { - Support: technical support } \\
\text { (silver support/gold } \\
\text { support/silver support) } \\
\text { - Training: Talend foundation } \\
\text { class, Talend advanced class } \\
\text { - Services: Talend POC program, } \\
\text { Talend quick start program, } \\
\text { Talend expert program, Talend } \\
\text { project program, Talend } \\
\text { deployment program, Talend } \\
\text { quality insurance program } \\
\end{array}$ & $\begin{array}{l}\text { Community, } \\
\text { forum, bug } \\
\text { tracker } \\
\text { - Wiki, blog }\end{array}$ \\
\hline 49 & Terracotta & 2003 & $\begin{array}{l}\mathrm{CA} \\
\text { USA }\end{array}$ & $\begin{array}{l}\text { Products: subscription (OS } \\
\text { version (TPL)/commercial } \\
\text { version), } \\
\text { - Services: a service level } \\
\text { (silver/gold), training (standard } \\
\text { training/custom courses and } \\
\text { onsite courses/certification } \\
\text { program), developer support } \\
\text { (jump start/enterprise } \\
\text { project/enterprise unlimited), } \\
\text { consulting (quick start/prime } \\
\text { time/enterprise analysis) }\end{array}$ & $\begin{array}{l}\text { Community, } \\
\text { forum } \\
\text { - Wiki, blog }\end{array}$ \\
\hline
\end{tabular}




\begin{tabular}{|c|c|c|c|c|c|}
\hline 50 & Terascala & 2005 & $\begin{array}{l}\text { MA, } \\
\text { USA }\end{array}$ & $\begin{array}{l}\text { - Products: The Terascala RTS } \\
1000 \text { run time storage appliance } \\
\text { + service and support (one year } \\
\text { service and support contract) } \\
\text { - Support: online support, } \\
\text { superior technical support }\end{array}$ & \\
\hline 51 & $\begin{array}{l}\text { Transera } \\
\text { Communicatio } \\
\text { ns }\end{array}$ & 2004 & $\begin{array}{l}\text { CA, } \\
\text { USA }\end{array}$ & $\begin{array}{l}\text { Products: Seratel }{ }^{\mathrm{TM}} \text { - on-demand } \\
\text { virtual call center software } \\
\text { (enterprises/outsourcers/service } \\
\text { providers) } \\
\text { - Services: customer support } \\
\text { (gold/standard), support login, } \\
\text { deployment, consulting, training }\end{array}$ & \\
\hline 52 & Univa UD* & 2004 & $\begin{array}{l}\mathrm{IL}, \\
\text { USA }\end{array}$ & $\begin{array}{l}\text { Products: UniCluster express } \\
\text { (free, community-enabled OS } \\
\text { cluster management product), } \\
\text { UniCluster Pro packs, Grid MP } \\
\text { (OS), Insight } \\
\text { - Solutions: clusters, desktops, } \\
\text { grids, reporting \& analytics } \\
\text { - Services \& support: service } \\
\text { offerings (grid assessment/grid } \\
\text { and cluster implementation/grid } \\
\text { and cluster application } \\
\text { adaptation), support offerings } \\
\text { (gold/platinum/customer portal) } \\
\text { Training: cluster and grid } \\
\text { overview, tools and } \\
\text { administration, developer } \\
\text { academy, installation training, } \\
\text { system administration training, } \\
\text { application enablement training, } \\
\text { support services training, } \\
\text { workshop }\end{array}$ & $\begin{array}{l}\text { Community, } \\
\text { forum } \\
\text { - Wiki, blog }\end{array}$ \\
\hline 53 & Untangle & 2003 & $\begin{array}{l}\text { CA, } \\
\text { USA }\end{array}$ & $\begin{array}{l}\text { Products: the Untangle gateway } \\
\text { platform (OS/GPL v2), } \\
\text { Untangle professional package, } \\
\text { Kaspersky Virus Blocker, Pre- } \\
\text { Installed Untangle Servers, } \\
\text { applications (OS/commercial } \\
\text { add-on) } \\
\text { - Support: documentation, } \\
\text { Untangle forums, user mailing } \\
\text { list or IRC channel }\end{array}$ & $\begin{array}{l}\text { Community, } \\
\text { forum, mailing } \\
\text { list, IRC (Internet } \\
\text { Relay Chat) } \\
\text { - Wiki, blog }\end{array}$ \\
\hline 54 & VirtualLogix & 2002 & $\begin{array}{l}\text { CA, } \\
\text { USA }\end{array}$ & $\begin{array}{l}\text { Products: VirtualLogix TM VLX, } \\
\text { VLX for Network } \\
\text { Infrastructure, VLX for Mobile } \\
\text { Handsets, VLX Embedded, } \\
\text { VLX Developer } \\
\text { - Services: customer project, } \\
\text { consulting, training; } \\
\text { - Support: standard support, } \\
\text { platinum support }\end{array}$ & \\
\hline
\end{tabular}




\begin{tabular}{|c|c|c|c|c|c|}
\hline 55 & VirtualIron & 2003 & $\begin{array}{l}\text { MA, } \\
\text { USA }\end{array}$ & $\begin{array}{l}\text { Solutions: server consolidation, } \\
\text { rapid provisioning, business } \\
\text { continuity, capacity } \\
\text { management, virtual } \\
\text { infrastructure management, } \\
\text { development and test, virtual } \\
\text { hosted desktop infrastructure } \\
\text { - Products: enterprise-class } \\
\text { software for server } \\
\text { virtualization \& virtual } \\
\text { infrastructure management, } \\
\text { [The Virtual Iron platform } \\
\text { consists of three components: } \\
\text { Virtualization Manager, } \\
\text { Virtualization Services, Open } \\
\text { Source Virtualization (GPL)] } \\
\text { Services \& support: support } \\
\text { lifecycle (general } \\
\text { support/extended } \\
\text { support/technical guidance), } \\
\text { professional services }\end{array}$ & \\
\hline 56 & Vyatta & 2005 & $\begin{array}{l}\text { CA, } \\
\text { USA }\end{array}$ & $\begin{array}{l}\text { Products: software combines } \\
\text { enterprise-class router, firewall } \\
\text { and VPN with OS (GPL) } \\
\text { solutions, community edition, } \\
\text { professional subscription, } \\
\text { enterprise subscription, } \\
\text { hardware appliances } \\
\text { (professional } \\
\text { subscription/enterprise } \\
\text { subscription) } \\
\text { Professional services: remote } \\
\text { consulting services, community } \\
\text { support } \\
\text { Training: Vyatta university, } \\
\text { course catalog, delivery options } \\
\text { (on-site/online) }\end{array}$ & $\begin{array}{l}\text { Community, } \\
\text { forum, blog, } \\
\text { secret society }\end{array}$ \\
\hline 57 & Wikia & 2004 & $\begin{array}{l}\text { CA, } \\
\text { USA }\end{array}$ & $\begin{array}{l}\text { Services: basic wiki editing, } \\
\text { advanced wiki editing, wiki- } \\
\text { based search }\end{array}$ & $\begin{array}{l}\text { Community, } \\
\text { forum, IRC } \\
\text { - Wiki, blog }\end{array}$ \\
\hline 58 & WSO2 & 2005 & $\begin{array}{l}\text { CA, } \\
\text { USA }\end{array}$ & $\begin{array}{l}\text { Products: SOA platform } \\
\text { (OS/Apache License/consisting } \\
\text { of an application server, an } \\
\text { enterprise service bus, a mashup } \\
\text { server, a registry \& repository } \\
\text { and more) } \\
\text { - Support: development support, } \\
\text { production support } \\
\text { (silver/gold/platinum) } \\
\text { Training: live online training, } \\
\text { onsite training } \\
\text { - Services: consulting, OS } \\
\text { development sponsorship }\end{array}$ & $\begin{array}{l}\text { Community, } \\
\text { forum } \\
\text { - Wiki, blog }\end{array}$ \\
\hline
\end{tabular}




\begin{tabular}{|c|c|c|c|c|c|}
\hline 59 & Xandros* & 2001 & $\begin{array}{l}\text { NY, } \\
\text { USA }\end{array}$ & $\begin{array}{l}\text { Products: Xandros server, } \\
\text { Xandros home edition, Xandros } \\
\text { networks, Versora progression } \\
\text { desktop, Xandros desktop } \\
\text { operation system (home } \\
\text { edition/home edition/premium } \\
\text { professional) } \\
\text { - Support: forums, technical } \\
\text { support, web-based support, } \\
\text { migration strategies and tools }\end{array}$ & \\
\hline 60 & Zenoss* & 2005 & $\begin{array}{l}\text { MD, } \\
\text { USA }\end{array}$ & $\begin{array}{l}\text { Products: Zenoss Core OS } \\
\text { edition (GPL v2), enterprise } \\
\text { edition, subscriptions } \\
\text { (community, core support, } \\
\text { enterprise silver, enterprise } \\
\text { gold) } \\
\text { - Consulting: plan and } \\
\text { architecture, deployment, } \\
\text { customization, integration, } \\
\text { instrumentation } \\
\text { Training: specific topics } \\
\text { (modeling your } \\
\text { environment/availability } \\
\text { monitoring/performance } \\
\text { monitoring/event management } \\
\text { and log monitoring/alerting } \\
\text { rules and methods/templates and } \\
\text { plugins/system tuning and } \\
\text { maintenance) }\end{array}$ & $\begin{array}{l}\text { Community, } \\
\text { forum, IRC } \\
\text { - Wiki, blog }\end{array}$ \\
\hline 61 & Zmanda & 2005 & $\begin{array}{l}\text { CA, } \\
\text { USA }\end{array}$ & $\begin{array}{l}\text { - Products: Amanda community } \\
\text { edition (GPL), Amanda enterprise } \\
\text { edition (basic/standard/premium), } \\
\text { Zmanda recovery manager for } \\
\text { MySQL community edition (GPL), } \\
\text { Zmanda recovery manager for } \\
\text { MySQL enterprise edition (annual } \\
\text { subscription) } \\
\text { - Services: QuickStart, } \\
\text { implementation services, solution } \\
\text { services, continuity and compliance } \\
\text { consulting } \\
\text { - Support: Zmanda network (free } \\
\text { subscription/basic/standard/premiu } \\
\text { m) }\end{array}$ & $\begin{array}{l}\text { - Community, forum } \\
\text { - Wiki, blog }\end{array}$ \\
\hline
\end{tabular}

